\title{
Thoracodorsal sympathectomy in patients with ischaemic handphenomena Eric Joan Hendrik van Rhede van der Kloot
}

Citation for published version (APA):

van Rhede van d Kloot, E. J. H. (1988). Thoracodorsal sympathectomy in patients with ischaemic handphenomena Eric Joan Hendrik van Rhede van der Kloot. [Doctoral Thesis, Maastricht University]. Rijksuniversiteit Limburg. https://doi.org/10.26481/dis.19880226er

Document status and date:

Published: 01/01/1988

DOI:

10.26481/dis.19880226er

Document Version:

Publisher's PDF, also known as Version of record

Please check the document version of this publication:

- A submitted manuscript is the version of the article upon submission and before peer-review. There can be important differences between the submitted version and the official published version of record.

People interested in the research are advised to contact the author for the final version of the publication, or visit the DOI to the publisher's website.

- The final author version and the galley proof are versions of the publication after peer review.

- The final published version features the final layout of the paper including the volume, issue and page numbers.

Link to publication

\footnotetext{
General rights rights.

- You may freely distribute the URL identifying the publication in the public portal. please follow below link for the End User Agreement:

www.umlib.nl/taverne-license

Take down policy

If you believe that this document breaches copyright please contact us at:

repository@maastrichtuniversity.nl

providing details and we will investigate your claim.
}

Copyright and moral rights for the publications made accessible in the public portal are retained by the authors and/or other copyright owners and it is a condition of accessing publications that users recognise and abide by the legal requirements associated with these

- Users may download and print one copy of any publication from the public portal for the purpose of private study or research.

- You may not further distribute the material or use it for any profit-making activity or commercial gain

If the publication is distributed under the terms of Article $25 \mathrm{fa}$ of the Dutch Copyright Act, indicated by the "Taverne" license above, 


\section{Thoracodorsal Sympathectomy in Patients with \\ Ischaemic handphenomena}

\section{Proefschrift}

ter verkrijging van de graad van doktor in de geneeskunde aan de Rijksuniversiteit Limburg te Maastricht, op gezag van de Rector Magnificus, Prof. Dr. F.I.M. Bonke, volgens het besluit van het College van Dekanen, in het openbaar te verdedigen op vrijdag 26 februari 1988 des namiddags te twee uur

door

Eric Joan Hendrik van Rhede van der Kloot geboren te Leiden 
Promotores: Prof.Dr. J.M. Greep

Prof.Dr. H.A.J. Lemmens

Compromotor: Dr. P.J.G. Jörning

Referenten: Prof.Dr. J. Drukker

Prof.Dr. B.K. Janevski

Prof.Dr. S.H. Skotnicki

The publication of this thesis was financially supported by the Dutch Heart Foundation, Stichting het Scholten-Cordes Fonds and Jan Dekkerstichting \& Dr. Ludgardine Bouwmanstichting. 
To Patty, Lars, Kai and David To the memory of my Grand-father 
Chapter I

Introduction

Chapter II The state of the art

II.1 History of thoracic sympathectomy 9

II.2 Indications 12

II.3 The extension of sympathectomy 12

II.4 Explanations of failures 13

II.5 Operative techniques, their advantages and disadvantages 15

II.6 Objective methods used for evaluation of post-operative results 17

Chapter III Description of patients investigated for this thesis 21

Chapter IV Preoperative valụe of angiography in the patients presented in this study 25

$\begin{array}{lll}\text { IV.1 Introduction } & 25\end{array}$

IV.2 Material and methods $\quad 26$

$\begin{array}{lll}\text { IV. } 3 \text { Results } & 27\end{array}$

IV.4 Discussion 33

IV.5 Conclusions 34

$\begin{array}{lll}\text { Chapter V Operative techniques } & 35\end{array}$

V.1 Technique for thoracodorsal sympathectomy 'en bloc' 35

V.2 Technique for re-sympathectomy 38

$\begin{array}{lll}\text { Chapter VI Anatomical study } & 39\end{array}$

$\begin{array}{lll}\text { VI. I Introduction } & 39\end{array}$

$\begin{array}{ll}\text { VI.2 Methods and material } & 40\end{array}$

$\begin{array}{lll}\text { VI.3 Results } & 40\end{array}$

VI.4 Discussion 46

VI.5 Conclusions 47

Chapter VII Results of the Thoracodorsal sympathectomy 'en bloc' 49

VII. Patients and methods 49

VII.2 Results 51

VII.3 Complications 55

VII.4 Discussion $\quad 57$

VII.5 Conclusions $\quad 59$

Chapter VIII Re-sympathectomy 61

VIII.1 Introduction $\quad 61$

VIII.2 Patients and methods 61 
VIII.3 Results 62

VIII.4 Complications $\quad 64$

$\begin{array}{lll}\text { VIII.5 Discussion } & 64\end{array}$

VIII.6 Conclusions 65

Chapter IX Evaluation of the value of angiography in selecting patients for sympathectomy 67

$\begin{array}{lll}\text { IX.1 Introduction } & 67\end{array}$

$\begin{array}{ll}\text { IX.2 Patients and methods } & 67\end{array}$

$\begin{array}{lll}\text { IX.3 Results } & 67\end{array}$

IX.4 Discussion 71

$\begin{array}{ll}\text { IX.5 Conclusions } & 72\end{array}$

Chapter X Continuous Wave Doppler

A quantitative Doppler study to evaluate postoperative results $\quad 73$

$\begin{array}{lll}\text { X.1 Introduction } & 73\end{array}$

$\begin{array}{lll}\text { X.2 Material and methods } & 73\end{array}$

$\begin{array}{lll}X .3 & \text { Results } & 75\end{array}$

$\begin{array}{lll}\text { X.4 Discussion } & 76\end{array}$

$\begin{array}{lll}\text { X.5 Conclusions } & 77\end{array}$

$\begin{array}{lll}\text { Chapter XI General discussion and conclusions } & 79\end{array}$

$\begin{array}{lll}\text { Chapter XII Summary } & 83\end{array}$

Chapter XIII Samenvatting $\quad 85$

$\begin{array}{lr}\text { References } & 89\end{array}$ 



\section{Chapter I}

\section{Introduction}

Thoracic sympathectomy for sympathetic denervation of the upper extremity in patients with ischaemic hand phenomena is complicated by the high percentage of recurrences. Many operative procedures have been proposed and then modified in order to overcome this problem but recurrences are still seen. Many explanations have been given for the postoperative failures. The most accepted explanations are regeneration of sympathetic fibres and variability in the anatomy of the sympathetic nervous system in relation to and connection with the spinal nervous system.

In $1927 \mathrm{Kuntz}$ (78) described an anatomical variant. His anatomical study showed an intrathoracic nerve by which sympathetic fibres could reach the brachial plexus without passing through the sympathetic trunk thus accounting for potential failure of sympathectomy.

A modified surgical procedure was introduced by Lemmens therefore (88). This extended sympathectomy by the posterior approach was called the thoracodorsal sympathectomy 'en bloc' (T.D.S. 'en bloc').

As well as the resection of the first, the second and the third thoracic sympathetic ganglia, the second and third intercostal nerves, the intrathoracic nerve of Kuntz and surrounding tissue containing other possible sympathetic fibres which could bypass the sympathetic trunk were all resected in toto. This thoracodorsal sympathectomy 'en bloc' has been routinely performed since 1975 in the University Hospital of Maastricht in patients with ischaemic hand phenomena.

The aim of this thesis has been:

- To perform an anatomical study of the resected tissue specimens in order to identify the intrathoracic nerve described by Kuntz and to investigate the variability in the connections between the sympathetic and spinal nerve systems.

- To evaluate the value of angiography in patients presented in this study in order to discover if there is any relationship between pathological angiographic signs and preoperative complaints and symptoms, and if it is possible to select patients by angiography for whom sympathectomy 'en bloc' would be beneficial.

- 'To evaluate the results of the thoracodorsal sympathectomy 'en bloc' and to ascertain if this extended technique resulted in a decrease in the high rate of recurrences.

- To investigate the use of the continuous wave Doppler as objective method for evaluation of the effect of sympathectomy.

- To analyze the possibility of a re-sympathectomy by the thoracodorsal approach, when in a previous operation the upper thoracic ganglia are already resected with transient succes.

It is clear that sympathectomy of the upper extremity is only part of the solution in the treatment of ischaemic hand phenomena. By an evaluation of results in combination with the anatomical study, angiography and continuous wave Doppler the place of the sympathectomy in this crux medicorum is analysed. 



\section{Chapter II}

\section{The state of the art}

The history of the upper thoracic sympathectomy is of importance. In the past, upper thoracic sympathectomies have been recommended for relief of a considerable variety of conditions. Techniques of surgical sympathetic denervation of the upper extremity vary with regard to the operative approach in accordance with the extent of the sympathetic rami which are to be removed.

A review of the surgical techniques used, and their varying indications will be presented. Many explanations for changing the surgical technique will be discussed and hypotheses explaining the causes of failure of operations will be summarized. Finally the techniques for evaluating the effect of surgery are reviewed.

\section{1 History of thoracic sympathectomy}

In 1852 Claude Bernard (20) studied the influence of the sympathetic nervous system on the body temperature of warm blooded animals. He noted that the entire part of the head which became hot after the resection of one cervical sympathetic chain, also became the seat of more active circulation of the blood. He first ascribed the concomitant vasodilatation to the increased metabolism of the tissue, but later he realized that it was actually due to the release of vasoconstrictive tone after the division of the sympathetic fibres. Subsequent experimental work brought a detailed description of the regulation of vasomotor tone by the autonomic nervous system in warm blooded animals $(30,82)$. Alexander (4) in 1889 was the first to operate on patients on the autonomic nervous system. He postulated that in interrupting the pathways responsible for excessive sympathetic discharge in patients suffering from epileptic fits he could stop this phenomenon by resecting both the superior sympathetic ganglia. Jaboulay in 1896 described an operation to treat exophthalmic goitre by resecting the cervical sympathetic chain but this operation did not have any success. He also described a patient who was relieved of angina pectoris after removing the stellate ganglion. Sympathectomy for patients with trophic disorders of hands and feet was first described by Jaboulay (62) in 1899. He resected the vascular plexus from the subclavian and femoral arteries, believing that these nerves compressed the main arteries, so causing anaemia, and subsequently, pain and ulcers. Leriche (92) in 1913 was the first to introduce periarterial sympathectomy for relief of symptoms in patients with Raynaud's syndrome, in the belief that the syndrome was caused by an inflammation of the sympathetic nerves. Careful experimental and clinical studies by Wiedkopf (157) in 1923 made it clear that the operation of Leriche did not bring the desired results. Kramer and Todd (77) in 1924 proved that the anatomical base on which the results were claimed was wrong. Their observations suggested that the sympathetic fibres pursued a short course in the periarterial plexus and that the main supply of the vessels in the distal part of the limb, reaches them along the vascular branches from the main nerves of the limb. This was confirmed by the fact that an ulnar nerve block at the elbow resulted in an increase in skin temperature and electrical resistance in the finger the same as that associated with recent sympathectomy. 
At 1924 Royle and Hunter $(59,122)$ designed a method for relieving the complaints in patients with spastic paralysis. They discovered that resection of sympathetic rami, to release muscle tone, produced a striking improvement in the circulation in hands and feet. Bruning and Stahl (24) reported in the same year the effect of resection of the stellate ganglion in patients with Raynaud's phenomenon. They reported improved results compared to the periarterial sympathectomy. Cervicodorsal ganglionectomy was abandoned however because of the disadvantage of the postoperative Horner's syndrome. Gask (44) in 1934 recommended a slightly modified technique for treating patients for a variety of vasospastic disorders. He resected not only the stellate ganglion but also the second thoracic ganglion. By this operation most patients were relieved of their complaints although the long-term results were disapponting.

In the meantime the results of a sympathectomy of the lower extremity had been gratifying $(92,114,143)$. This was a preganlionic denervation in which the sympathetic fibres were divided before they reached the sacral ganglia which held the perikarya for the territory of the sciatic nerve. There was reason to expect similar improvement if the upper extremity could be sympathectomized in the same manner. This procedure was introduced by Smithwick and Telford $(131,145)$ who developed a preganglionic sympathectomy for the upper extremity. The preganlionic sympathectomy consisted of dividing the preganglionic inflow of the second and third thoracic ganglia of the sympathetic trunk, and cutting the latter below the third ganglion (Fig. II.1).

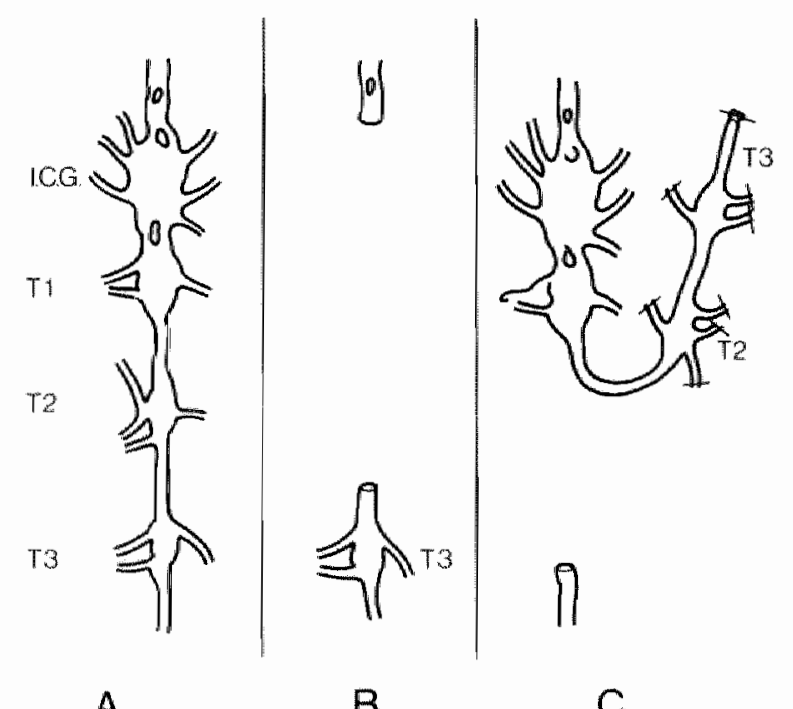

Figure II. I

a. Sympathetic chain with the inferior cervical ganglion (I.C.G.) and upper thoracic ganglia (D)

b. Siruation after cervicothoracic ganglionectomy (post-ganglionic)

c. Pre-ganglionic sympathectomy, Ganglia are not removed.

The stellate ganglion was left intact since the Horner syndrome was a great disadvantage and the results seemed to be the same even if this ganglion was not resected. These operations seemed to be the solution to the problem of recurrences, since after preganglionic sympathectomy the presence of residual sympathetic nerve supply to the 
upper extremity could not be demonstrated. The influence of the first thoracic ganglion seemed unimportant. Other clinical evidence supports this view, since most workers who have studied a considerable number of cases shortly after preganglionic operations in which the inflow from the first thoracic segment remained intact, have found no evidence of sympathetic activity in the hand $(14,128)$. In the follow-up period Smithwick and Telford also noted failures of this method. Exept for the possibility of regeneration, their explanation was a failure to interrupt the white rami of the second and third dorsal segments. Therefore they suggested also resecting parts of the second and third intercostal nerves $(130,131,132)$. This so called extraspinal root resection (Fig. II.2a) was performed for several years. Because of failures and the feeling that the anterior roots of the second and third intercostal nerves were more likely sources of regeneration fibres than the cut end of the sympathetic trunk the operation was further modified and termed intraspinal root resection.
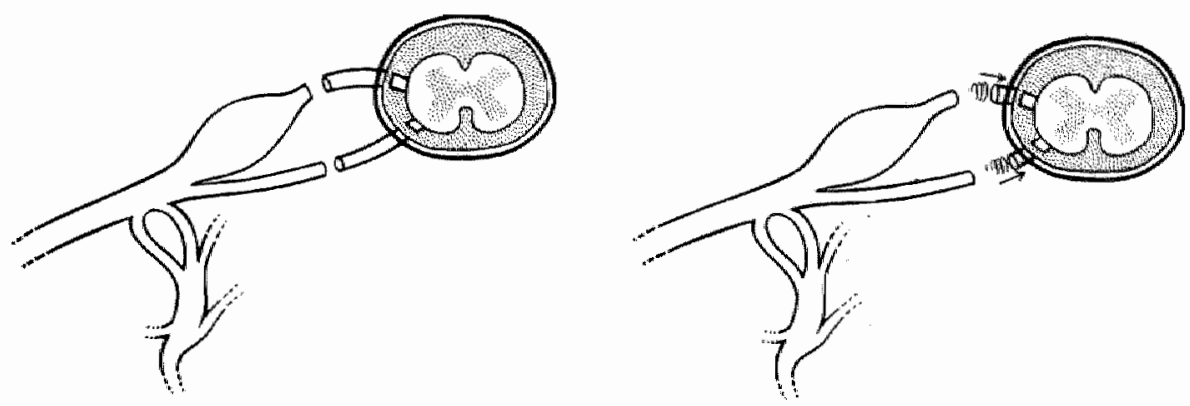

A

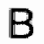

Figure 11.2

a. Extraspinal root resection.

b. Intraspinal root resection.

The roots are divided within the arachnoid.

A large portion of the intraspinal part of the anterior root was removed by separaling the attachment of the arachnoid and gently removing the root out (Fig. II.2b). This type of operation gave good short-term results, but relapses after one or two years occurred also. Felder et al (39) found that root resection of second and third intracostal nerves intradurally combined with ganglionectomy gave better late results. In 1953 Ray (114) recommended excision from the midcervical ganglion down to and including the thirct thoracic ganglion as the standard operation.

In all operations in which the stellate ganglion is also resected, Horner's syndrome is a great disadvantage. Palumbo (108) concluded that thorcic sympathectomy, including the removal of the first thoracic or lower portion of stellate ganglion, to and below the fourth or fifth thoracic ganglia, will not necessarily result in Horner's syndrome, but would interrupt all sympathetic supply to the upper extremity.

In 1959 Kux (80) reported a technique for endoscopic thoracic sympathectomy. He described good results in patients with upper limb hyperhydrosis (81). Milewski (102) and Waele (152) using the same technique, reported their results in patients with 
vasospastic and obstructive hand syndromes and these were similar to the results of operative approaches.

The first report of the technique used in this study was given in 1979 by Lemmens (88). He introduced the thoracodorsal sympthectomy "en bloc'. "This technique will be described in detail in chapter $V$.

\section{II.2 Indications}

As mentioned before at the end of the past century operations on the sympathetic nervous system were proposed and performed for several diseases such as epilepsy, exophthalmic goitre and migraine (71). Jaboulay and Henry (58) tried a thoracic sympathectomy to relieve a patient of angina pectoris. Jaboulay (62) was the first who operated for trophic disorders of hand and foot. For treatment of patients with Raynaud's syndrome Leriche (92) introduced his periarterial sympathectomy.

Haxton (54) first described a thoracic sympathectomy for hyperhydrosis of the axilla or the palms of the hands. Good results were confirmed by other authors $(1,29,81,95,136)$. In 1930 spurling (134) reported a series of patients with post-traumatic pain syndromes who were treated by thoracic sympathectomy with good results. Later in 1959 and 1973 large series of patients with post-traumatic pain syndromes were published $(34,109)$. The indications for thoracic sympathectomy have not been changed much over the last sixty years. Most patients operated on suffer from primary or secondary Raynaud's phenomenon, hyperhydrosis, occlusive peripheral vascular disease or post-traumatic pain syndromes.

Because of the high recurrence rate sympathectomy of the upper extremity is not frequently performed nowadays. Nevertheless, when other methods have failed, sympathetic denervation of the extremity is still recommended.

\section{3 The extension of sympathectomy}

Büning and Stahl (24) resected the stellate ganglion only. Gask (44) enlarged the operation. He resected not only the stellate ganglion but also the second thoracic ganglion. Smithwick and Telford recommended a preganglionic sympathecromy by dividing the white rami of the second or third ganglia and dividing the sympatheric chain below the third but left the ganglia themself in place. In the following years they recommended resection of the second and third intercostal nerves as well.

Baddeley (10) compared the effectiveness of extensive and less extensive denervations. The extent of denervation varied from total or hemistellate ganglionectomy the lower half of the stellate ganglion), together with removal of 2-5 thoracic, to removal of 2 or 3 thoracic ganglia alone. His conclusion was that extensive ganglionic sympathectomy had no advantage over less extensive denervations.

Despite all techrical advances it is still not clear which part of the sympathetic chain must be resected although resection of the complete stellate ganglion and intercostal nerves has been abandoned $(97)$. Most authors $(93,97,98,108,150,153)$ advise resection of the lower part of the stellate ganglion if there is no separate first thoracic sympathetic ganglion, in combination with removal of the second and third thoracic ganglia. Nevertheless there are authors $(19,123)$ who claim good results by resection of the second and third thoracic ganglia sometimes combined with resection of the fourth. 


\section{II.4 Explanation of failures Why does recurrence develop?}

The hypotheses given as explanation for unsuccesful operations are regeneration, auxiliary ganglia, incomplete denervation and hypersensitivity to adrenaline or a combination of these factors. They will be described separately.

\section{Regeneration}

Regeneration of sympathetic fibres was first demonstrated by Lee (86) in 1929 in cats. He verified the regrowth of divided symparhetic fibres by histological examination and also noticed return of function of the pupil and normal temperature of the limb of the cat. Another study by Kirgis (74) supported to this point of view. These results of these animal experiments, in combination with the return of vasomotor function in the hands of patients after several months, sometimes years, may suggest the explanation for operative failures in many patients.

Haxton (56) described a patient with Raynaud's disease in whom he carried out bilateral resection of the second and third thoracic ganglia. After two years of no complaints, she gradually developed such a severe relapse that a further operation was undertaken after medical treatment had failed. Return of vasomotor activity was proved by ulnar nerve block. The re-operation consisted of resecting the fibrous tissue over the heads of the second and third ribs on each side. The stellate ganglion with its connections was left intact. After operation the hand became dry and warm again and ulnar block showed that sympatheric activity was now absent in the fingers. The above evidence clearly indicate that the new fibres for the return of activity traversed the upper thoracic paravertebral area below the stellate ganglion. Haxton claimed the only likely explanation to be regrowth of divided fibres and restoration of functional continuity.

Smithwick and Telford $(131,145)$ also believed in regeneration as the cause of relapses and modified their operative techniques accordingly. Since most relapses occured more than one year postoperatively many authors suggested regeneration as cause for recurrences $(10,23,39,127,128)$. At re-operation Matassi (98) found a normal sympathetic chain, whereas in the first operation the second and third sympathetic ganglia had been resected. This was histologically confirmed. His explanation was total regeneration of the sympathetic chain.

\section{Auxiliary ganglia}

Accessory (ectopic) sympathetic ganglia were described in 1935 by Wrete (159) in the communicating rami of the sympathetic trunk in the embryo. Groen (51) confirmed the presence of intermediate ganglia in his study. Skoog (129) in 1947 found accessory ganglia for the upper extremity - at necropsy - in 5 adults. They lay in the spinal canal and by means of a small nerve, the vertebral nerve of Wrete, passed and linked up to the higher brachial plexus nerve roots. Each small ganglion received a white ramus, and a grey ramus proceeded from it. These ganglia and their connections may provide an alternative pathway for sympathetic impulses after the usual sympathectomy.

\section{Hypersensitivity to adrenaline}

Relapses usually occur after a period of six months to two years. Sometimes recurrences of vascular spasm are seen after about two weeks. Hypersensitivity of denervated tissue to circulating humoral factors could be the explanation. Experimental studies on animals 
indicate that resection of sympathetic nerve fibres distal to the sympathetic ganglia (postganglionic section) increase the contraction effect of adrenaline on smooth muscle more than preganglionic section of sympathetic ganglia. However both procedures increase the sensitivity of smooth muscle to adrenaline $(6,50)$.

In 1940 Fatherree (38) studied the vasoconstrictor effect of adrenaline on the digital vessels before and after post- or preganglionic sympathectomy. After these two types of operation for patients with Raynaud's disease of the hands he found an increased sensitivity of the digital arteries to adrenaline. The rate of increase was about the same in both instances. According to Fatherree (38) the sensitivity of arterioles to adrenaline has a limited relation with failure to cure Raynaud's disease by sympathectomy.

Simmons (128) measured skin temperature of hands and fingers after intravenous infusion of an adrenaline solution in patients after sympathectomy. He found maximum hypersensitivity to adrenaline 8-10 days after operation. It has to be noted that clinical relapses are not evident for several months. At the time when relapse becomes apparent the hypersensitivity to adrenaline is either non existent or very much diminished and it continuous to decrease whereas the relapse steadily becomes worse.

Duff (35) investigated the effect of adrenaline and noradrenaline on blood vessels of the hand before and after sympathectomy, by measuring the blood flow in the hand by venous occlusion plethysmography. He found an increase in vasoconstriction after sympathectomy in $50 \%$ of the patients. In the other $50 \%$ no increase in vasoconstriction was seen after infusion of adrenaline or noradrenaline. No difference was seen between patients with ganglionectomy or only preganglionic section. No clear rule for hypersensitivity as a source of relapses could be given.

By using a decrease in the temperature of the skin of the digits as a manifestation of sensitivity of arteriolar smooth muscle, Freeman, Smithwick and White (40) concluded, that postganglionic denervation increased the sensitivity of the arterioles to adrenaline injected intravenously or liberated in the blood from the suprarenal gland more than after a preganglionic section of sympathetic nerves.

Simeone (126) stressed that the important feature for consideration was not whether or not there is hypersensitivity to adrenaline or noradrenaline of the blood vessels in man after sympathetic denervation but whether or not it plays an important role in the incidence of recurrences after sympathectomy for vasospastic conditions. The review of literature on this subject gave many explanations. Most authors $(38,126,128)$ have finally agreed that the role of hypersensitivity to adrenaline or noradrenaline is of minor importence in the etiology of recurrences after sympathectomy.

\section{Incomplete denervation}

Adson (3) postulated that the recurrence of symptoms was not the result of regeneration of new fibres. It should be due to the formation of new synaptic connections in sympathetic ganglia with neurons which had probably been injured by retraction, but had not actually been divided and removed. He claimed that when he changed the operative approaches and increased the extent of the operations to assure complete interruption of all sympatheric rami carrying vasoconstriction to the vessels of the hand, the same satisfactory results obtained following lumbar sympathectomy could be reproduced after thoracic sympathectomy. The exact objective or subjective data of the patients treated were not mentioned.

In a study on cats Kuntz (79) described the role of the preganglionic components of the 
first thoracic nerve in the sympathetic innervation of the upper extremity.

Haxton (55) found very slight sympathetic activity persisting in four out of 55 thoracic sympathectomy patients after Telford's preganglionic operation. He postulated an occasional supply from the first thoracic segment of the upper limb. Felder (39) also suggested that residual autonomic pathways on basis of anatomical variation could account for these early relapses.

An intrathoracic nerve which connects the second intercostal nerve with the stellate ganglion or directly with the brachial plexus, was described by Kuntz in 1927 (78). He demostrated sympathetic fibres in this nerve branch. By this intrathoracic nerve it could be possible for sympathetic fibres to bypass the sympathetic chain. An anatomical study by Kirgis ( 73 ) in 44 cadavers demonstrated a ramus arising from the third intercostal nerve containing sympathetic fibres which could join the second thoracic nerve by bypassing the sympathetic ganglia.

These anatomical studies gave a possible explanation for many early relapses after thoracic sympathectomy.

Lemmens (89) believed also in incomplete denervation and described the possibility of a re-sympathectomy in 1.981. This technique will be explained in chapter V.2.

\section{II.5 Operative techniques}

\section{Advantages and disadvantages}

Several techniques for sympathetic denervation of the upper extremity have been advocated. Many approaches were developed in accordance with the extent of the sympathetic rami intended to be removed (Fig. II 3a-d).

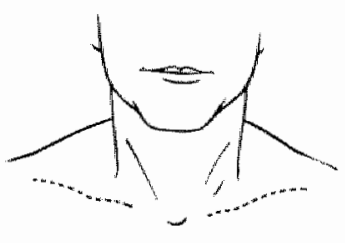

A

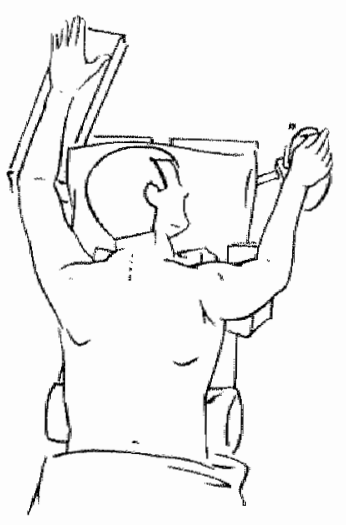

B
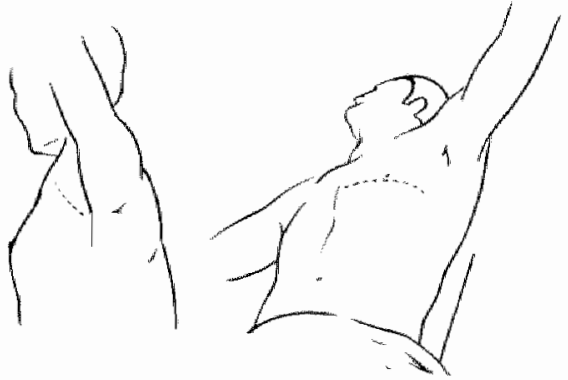

C

Figure II. 3

a-d Schematic representation of the various approaches to the sympathetic chain.

a: Supraclavicular

c. Transaxillar

b: Posterior

d: Anterior

\section{Supraclavicular approach}

This procedure was performed by Royle (122) through a supraclavicular incision and the insertion of the sternocleidomastoid muscle was divided. Gask (44) and Telford (145) also used this anterior incision for removing sympathetic ganglia, later called the 
supraclavicular approach. To prevent regeneration, Telford modified his technique. After dividing the sympatheric chain below the third thoracic ganglion, he sutured the distal end of the divided chain into the wound.

\section{Posterior approach.}

A posterior approach (for the unilateral removal of the stellate ganglion) was first introduced by Henry (58). Adson and Brown (2) described a method for bilateral resection of the upper thoracic sympathetic ganglia which could be used in patients with Raynaud's disease. For resection of the ganglia a part of the second rib and processus transversus of the second thoracic vertebra had to be resected in order to reach the sympathetic trunk. Smithwick (130) modified this dorsal sympathectomy. He left the stellate ganglion intact since Horner's syndrome was a great disadvantage and the results were the same when the second and third thoracic ganglia were separated. To prevent regeneration he changed his technique by bringing the divided chain into the thorax and suturing it in to the paravertebral muscle. The divided chain was left in place. He also, as mentioned before, resected a part of the intercostal nerves in order to guarantee a complete ramisectomy as an additional safeguard against regeneration. By this approach the pleural cavity did not need to be opened.

\section{Transthoracic axillary approach}

The transthoracic axillary approach through a transverse incision in the second or third intercostal space was first described by Schulze and Goetz and popularized by Atkins ( 7 , 8 ) in 195.4. The operation consists of removal of the second and third thoracic ganglia with the chain; or alternatively (if strict preganglionic sympathectomy is desired) the chain is sectioned below the third ganglion and the white rami to this ganglion and to the second are divided. The pleural cavity has to be opened for this approach.

\section{Anterior approach}

The anterior transcostal access to the upper parts of the thoracic sympathetic chain without entering the pleural cavity has been described by Gary and Henry (43). The skin incision runs two finger breadths below the clavicle, from the chondrosternal junction to a point over the coracoid tip. The second rib and cartilage are removed without opening the pleura. By this way it is possible to resect from the stellate ganglion to the fourth ganglion.

Palumbo (107) introduced in 1956 the anterior transthoracic route, with a skin incision over the third intercostal space. The costal cartilage of the third rib was divided to permit greater exposure in the upper thoracic cage. The parietal pleura was incised and the sympathetic ganglia could be resected.

\section{Endoscopic sympathectomy}

The possibility of an endoscopic sympathectomy was introduced by Kux (80). After establishment of a pneumothorax, a thoracoscope was introduced into the pleural cavity. The telescope was equipped with a wire electrode, a grasping forceps and a suction coagulation probe for endoscopic electroresection of the sympathetic trunk. The pneumothorax was then relieved by suction and the trocar and the telescope withdrawn simultaneously as the lung expanded. The skin incision was closed with a single stitch. 


\section{Advantages and disadvantages}

All the approaches as described in the literature have their own merits and disadvantages.

\section{Supraclavicular approach}

Resections must be done deep in the root of the neck beneath the brachial plexus without injuring the phrenic nerve, subclavian and vertebral arteries, brachial plexus or pleura. Only the first and second ganglia can be removed under direct vision with this technique. The third ganglion which significantly contributes sympathetic fibres to the upper extremity, can not be resected.

An advantage is that both sides can be operated on at once.

\section{Posterior route}

The posterior approach by rib resection provides a direct and open route to the thoracic sympathetic trunk from the stellate ganglion down to the fourth segment. No vital structures obstruct the sympathetic chain. The exposure of the intercostal nerves permits an easy identification of sympathetic segments, and many prevent possible regeneration by resecting them. On the other hand the longlasting incisional pain is a serious draw-back in using this approach $(41,57,98)$.

\section{Axillary approach}

The axillary approach gives a good exposure and identification of the structures. Accurate excision of the sympathetic chain is possible, as is the avoidance of Horner's syndrome. The cosmetic results are excellent.

Little (94) compared supraclavicular and axillary approaches in eighteen patients. He concluded that the axillary approach is preferable on most occasions because of the superior exposure, the wider sympathetic excision and the good cosmetic results.

\section{Anterior approach}

The anterior approach can be carried out extra- or transpleurally. By this technique the surgeon can easily visualize the sympathetic chain. A great disadvantage especially in women is the scar in the third intercostal space and also division of the pectoralis major muscle.

\section{Endoscopic sympathectomy}

The only disadvantage of this procedure mentioned is that it cannot be performed in the presence of pleural adhesions (81).

\section{II.6 Objective methods for evaluation of the postoperative results}

The high percentage of recurrence after sympathectomy led to the development of several techniques for evaluating the results.

Felder in 1949 (39) and Simeone in 1963 (127) have noticed that relapse of complaints was mostly associated with return of sympathetic nervous activity. Barcroft and Hamilton (14) also found return of sympathetic activity in the upper extremity, but $70 \%$ of the patients were symptom-free.

An explanation for the discrepancy must be the difference in follow-up period. Barcroft saw his patients within $11 / 2$ years postoperatively whereas Felder had a postoperative follow-up period from 6 months to 20 years. It is known that recurrence of symptoms after 
sympathectomy is mostly seen after $11 / 2$ or 2 years postoperatively, so in Barcroft's study more recurrences could be expected with a longer follow-up period. A possible relation between the return of symptoms and return of sympathetic activity was not mentioned by Barcroft. Many authors agree that there is a correlation between return of sympathetic activity and recurrence of complaints $(3,57,130)$.

There are several objective methods for evaluation of the presence or absence of sympathetic activity.

\section{Sweat tests}

In 1927 Minor (103) published the starch-iodine test as an indicator for sweating. Hyndman and Wolkin 1941 (60) studied the distribution of sweat fibres from the sympathetic ganglia by the same method. Patients were placed in a heating cabinet and the starch-iodine test was used as an indicator of sweating. After ganglionectomy a zone of absolute anhydrosis was found.

Richter (117) described in 1946 a method for measuring skin resistance in order to detect sympathectomized regions. He developed a dermometer to measure cutaneous resistance, because resistance decrease varied inversely with the sympathetically produced anhydrosis.

\section{Temperature measurement}

The elevation of skin temperature of the hand and fingers has been used by many authors to assess the effect of a sympathectomy $(9,128,130)$. Other authors $(119,158)$ have recommended the study of temperature patterns from pictorial records. Koikkalainen (76) used this technique to evaluate his results after sympathectomy.

\section{Sudomotor and vasomotor test}

In 1948 Barcroft and Hamilton (14) described sudomotor and vasomotor tests and their use for evaluation after sympathectomy.

The resistance to the passage of an electric current through the body is located almost entirely in the skin and is determined chiefly by the activity of the sweat glands. This activity depends on nervous excitation mediated through sympathetic fibres. The feet were heated to encourage free sweating. The currents which followed through the pads of the thumb and middle and little fingers were measured in $\mu \mathrm{A}$, and the average of them was called the current difference. Normal hands have current differences of $20 \mu \mathrm{A}$ or more, since the skin is moist. In fully sympathectomized hands current differences are negligible.

The vasomotor test consists of warming the feet and causing a reflex increase in blood flow in the hands. The efferent timb of the reflex is running from the central vasomotor centre through sympathetic fibres. In the absence of sympatheric connections to the limb heating of the feet does not alter the bloodflow.

\section{Plethysmography}

A simple plethysmographic method for determining the change in blood flow in the hand after sympathectomy was studied by Barcroft and Walker (15). It was based on the principle that a cuff around an extremity can be inflated to such a pressure that the draining veins are completely occluded while the inflow of blood through the arterial system is not impeded. The increase in volume of the extremity during venous occlusion is determined with a plethysmograph. The blood volume flow can be calculated from this 
increase as a function of time. The velocity of the blood flow will increase afrer sympathectomy.

\section{Blood flow wave form analysis}

In 1970 Lee (85) tried to give a measure of the arterial pulsatile blood flow wave form in peripheral vascular disease. The wave forms described were measured with a square wave electromagnetic flowmeter with non cannulating probes. Several parameters of the recorded wave form were measured in patients who had undergone a lumbar

sympathectomy. He concluded that sympathectomy produced an increase in the effective blood flow. The recorded blood flow wave forms showed a baseline shift and an increase in peak amplitude after operation.

\section{Continuous wave Doppler}

Introduction of transcutaneous flow detection in the arterial system gave a new opportunity for the evaluation of postoperative results in vascular surgery (141). The technique used is the ultrasonic determination of flow velocity by the Doppler principle. The diagnostic value of this technique has been demonstrated by a number of authors $(118,139,140)$. Fronek (42) introduced a quantitative ultrasonographic study of lower extremity flow velocity in healthy persons and patients with obstructive arterial lesions in the lower extremity. One of the most sensitive parameters was the peak forward velocity. Rittenhouse (120) showed that changes in peripheral resistance of the vascular bed were reflected in some parameters of the Doppler maximum frequency wave proximal to the pathology. One of these was the peak forward flow.

Successful interruption of sympathetic vasoconstrictor nerves results in arteriolar dilatation and a decrease in the vascular resistance. 



\section{Chapter III}

\section{Description of patients investigated and operated on.}

The nomenclature of ischaemic hand phenomena has always been a point of discussion. In literature many different terms and definitions such as primary and secondary Raynaud's syndrome, phenomenon or disease have been used to describe the same Raynaud's phenomenon. The term Raynaud's phenomenon is used consistently throughout this thesis. The terms primary and secondary indicate the absence or presence of an underlying disease, respectively. Asphyxia manus et digitorum is considered as a different phenomenon, characterised by a local, sharply bordered discoloration of one or more fingers.

In this study the clinical classification and nomenclature of Lemmens (87) has been used. This nomenclature is as follows:

Primary Raynaud's phenomenon is characterised by a symmetrical "painless" triphasic discouloration of hands and fingers, triggered by exposure to cold or emotional stress, in which no underlying disease can be found.

If only a single peripheral occlusion in one of the digital arteries was demonstrated by angiography, and if this finger could not be distinguished on clinical symptoms from the others, the patient was diagnosed as having primary Raynaud's phenomenon.

Secondary Raynaud's phenomenon is a phenomenon in which the clinical symptoms were similar to those observed in primary Raynaud's phenomenon. In these cases the phenomenon is based on a proven underlying disease.

"Asphyxia manus et digitorum" was characterised by a sharply bordered white, and sometimes cyanotic discolouration of one or more fingers or hand, especially after cold provocation. The underlying disease is an obstructive digital artery disease. This local ischamic phenomenon will be called asphyxia in the following study.

Another group of patients analysed in this study were those with traumatic pain syndromes. Several patients with post-traumatic dystrophy and one patient with causalgia were treated by sympathectomy.

Post-traumatic dystrophy is one of the variety of names given to a dystrophic pain-state of an extremity following trauma, infection, trombophlebitis or other lesions in whith the burning pain is out of proportion to the original injury.

The patients with post-traumatic dystrophy were classified as described by Drucker (34), Three different stages could be distinguished (Table III.1).

Causalgia was defined as: a burning type of pain not confined to the distribution of a peripheral nerve, occurring after tratuma to a major nerve of an extremity.

The distribution of patients in the different groups was as follows (Fig. III. 1):

1. Primary Raynaud's phenomenon

A total of 45 patients ( 33 female, 12 male), were classified as having primary Raynaud's phenomenon ( 30 patients underwent a bilateral procedure). The mean age in this group was 38 years (range 22-65). In none of the patients could any underlying disease be detected, either by physical examination or laboratory data. All laboratory data, 
Rose, Latex, lupus erythematosus factor were normal and investigation for cryoglobulins and agglutinins were negative.

2. Secondary Raynaud's phenomenon

16 Parients (15 female, 1 male) were classified as having secondary Raynaud's phenomenon ( 9 patients underwent a bilateral procedure). The mean age in this group was 50 years (range 46-61). The proven underlying disease was progressive systemic sclerosis (P.S.S.). The diagnosis P.S.S. was verified by histological skin biopsy examination or $\mathrm{X}$-ray examination of the oesophagus.

3. Asphyxia

27 Patients ( 10 female, 17 male) were classified as having "asphyxia manus et digitorum" ( 2 patients underwent a billateral procedure). The mean age in this group was 49 years (range 27-65). Angiography demonstrated obstructive lesions in the digital arteries of the affected fingers. The diagnosis was a hypothenar hammer syndrome in 5 patients, arteriosclerosis in 9 patients and tromboangiitis in 7 patients. In 6 patients microemboli were found ( 5 without known origin and one with the a thoracic outlet syndrome including damage to the wall of the subclavian artery).

4. Post-traumatic dystrophy

14 Patients ( 8 female, 6 male) were classified as having post-traumatic dystrophy. The mean age in this group was 41 years (range 23-54).

Four patients had sustained fractures of the upper extremity, 6 patients had trauma without iractures, 2 patients developed post-traumatic dystrophy after surgery for infection in the anterior closed space of the terminal phallanx of a finger, and 2 patients developed a post-traumatic dystrophy after first rib or cervical rib resection. Five patients were classified in stage II, the other 9 patients were in stage III of disease as defined by Drucker (34) (Table III.1).

Indication for operation was the continuous burning pain. Diagnosis were made by clinical history, physical and X-ray examination.

5. Causalgia

One patient (male aged 57) was treated for burning pain of his left upper extremity after amputation. His arm was amputated after a gunshot injury.

In these 103 patients 144 sympathectomies 'en bloc' ( 41 bilateral procedures) were performed.(Fig. III.2. Table III.2).

In 76 patients this operation was the "primary" operation ( 31 bilateral procedures). In 25 patients the thoracodorsal sympathectomy "en bloc" was performed as a resympathectomy. There were 8 bilateral procedures; in earlier operations the sympathetic ganglia had been removed with only transient success.

Two patients with bilateral operations had a re-sympathectomy on one side and a 'primary' on the orher side. 


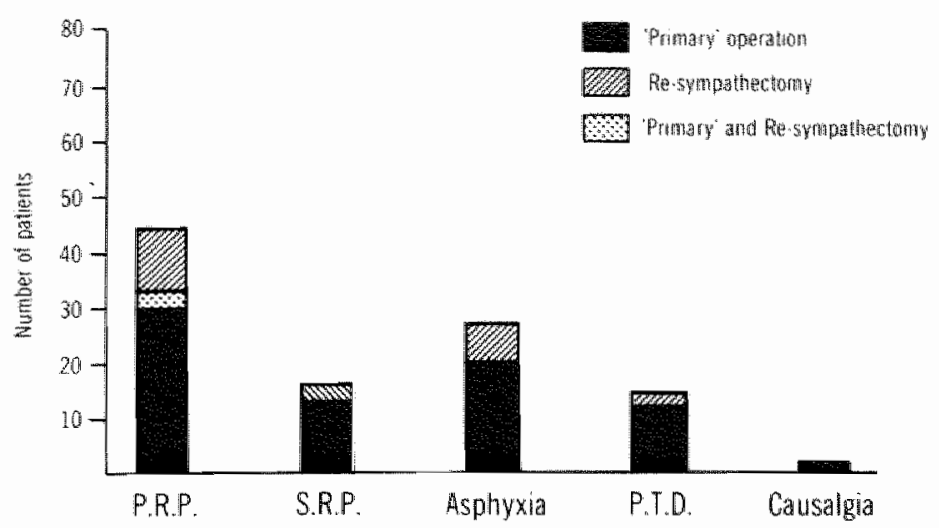

Figure III. L

Number of patients subdivided to indication for operation.

'Primary' and Re-symparhectomy are presented.

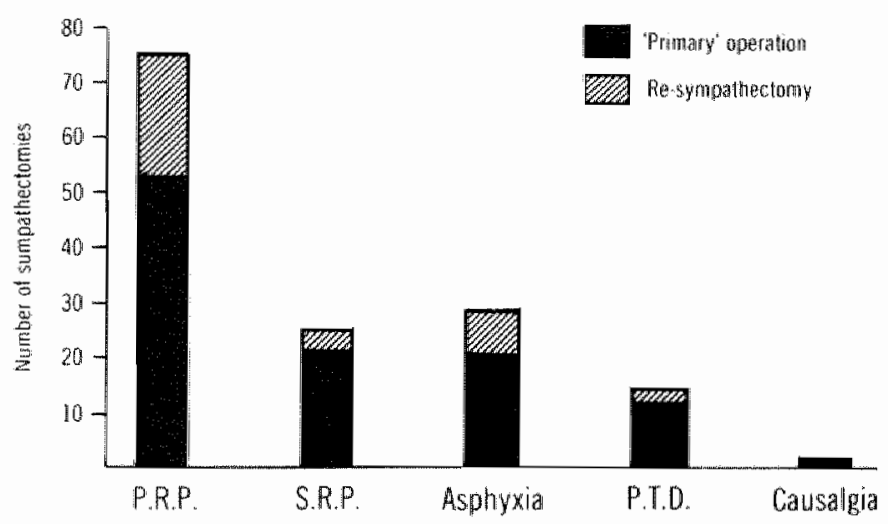

Figure TII.2

Number of thoracic sympathectomies subdivided to indication for operation.

'Primary" and Re-sympathectomy are presented. 
Table III.1:

Stages in posttraumatic dystrophy.

Stage 1: - increase in dermal bloodflow

- hyperthermia

- increased growth of hair

- increased nail growth

hyperhidrosis

- oedema

- constant burning or aching pain in the extremity

- pain out of proportion to the initial injury

- limitation of movement

Stage 2: - sikin cool, pale, grey and frequently cyanotic

- oedema with glazed overlying skin

- scanty hair growth

- brittle nails.

- increasing diffuse pain

- motility continues to decrease.

- radiographic bone changes showing spotty demineralisation

Stage 3: - decreased dermal bloodflow

- atrophic skin

- decreased fat pads in the fingers

- widespread neuralgia

- stiff hand

- decalcification of bone

Table III.2:

Number of patients and sympathectomies subdivided in 'primary' and resympathectomy.

Patients $(\mathrm{N}=103)$ Procedures $(\mathrm{N}=144)$

76 'primary" operation

(31 billateral)

25 re-sympathectomy

( 8 bilateral)

33

2 'primary' + re-sympathectomy

( 2 bilateral) 


\section{Chapter IV}

\section{Preoperative value of angiography in the patients presented in this study}

\section{IV.1 Introduction}

The use of angiography in patients with vasospastic and obstructive hand syndromes has been extensively described $(65,68,72,76,84,96,100,115,125,148)$. Opinions about the usefulness of this invasive technique differ among various authors. While some $(96,121$, 125) consider it valuable, particularly for exclusion of organic vascular changes or evaluation of the results of various forms of therapy, others $(72,155)$ consider it to present limited information for the diagnosis and management of vasospastic or obstructive hand syndromes. The angiograms have consistently revealed two signs:

organic obstructive lesions and smooth, concentric vascular alternation interpreted as spasm.

Wellington (155) believed that the presence or absence of digital artery obstruction could usually be established on clinical grounds and reserved brachial angiography for cases in which it was impossible to determine the presence of digital vessel obstruction by clinical means. Patients with obstructive lesions were, in his view, always associated with an underlying disease.

Several authors described the pathological signs found on angiograms in patients with progressive systemic sclerosis and Raynaud's phenomenon $(66,31)$.

Bergan (18) mentioned that in patients with prolonged symptoms of primary Raynaud's phenomenon changes could take place in the arterial wall which might lead to peripheral occlusion. He claimed that angiographic findings were related to the stage of disease. Retrori (115) and Servelle (125) confirmed this phenomenon in their angiographic studies.

Lyn (96) suggested that angiography of the arteries of the hands may be used to distinguish some of the various diseases which cause Raynaud's phenomenon and believed that the arteriographic appearances were useful in identifying those patients likely to benefit from sympathectomy. Patients with anatomically normal digital arteries should react. favourably to treatment with vasodilator agents and sympathectomy.

In 1977 Rösch (121) evaluated 47 patients with Raynaud's phenomenon and graded them separately for the presence of organic obstructive disease and functional vasospasm. He concluded that cryodynamic angiography of the hand with intra-arterially injected reserpine is diagnostically useful in patients with Raynaud's phenomenon, revealing the degree of organic arterial disease and functional vasospasm. He concluded also that the extent of obstructive disease corresponds with the severity of Raynaud's symptoms. A correlation between post-reserpine angiographic studies and observed clinical responses to long-term vasodilator drug therapy was claimed by Rösch. Kent (72) described the angiographic abnormalities found in 18 patients with Raynaud's phenomenon but they did not correlate with the clinically diagnosed underlying disease. His main conclusion, although the number of cases was small, was that angiographic examination was of limited 
value in patients with Raynaud"s phenomenon.

Because of this ambiguiry in literature another study was undertaken to examine the relation between angiographic appearances and the clinical diagnosis and also to study the possible relationship between complaints and severity of the angiographic findings. In chapter IX the value of angiography for selecting pacients who are suspected to react favourably after sympathectomy will be presented.

\section{IV.2 Material and methods}

In this study 121 angiographies of the upper extremity performed preoperatively in 85 patients who underwent a thoracic sympathectomy (36 bilateral), were available for investigation.

Angiography of the upper extremity and of the hand was performed exclusively by the percutaneous transfemoral catheterisation technique according to Seldinger. Radiographs were first taken of the upper arm in a neutral position i.e. parallel to the thoracic wall. In all patients, a second series of radiographs was taken with the upper arm in a provocative position to demonstrate or exclude a thoracic outlet compression syndrome. Consequently the catheter was introduced deep into the brachial artery for opacification of the arteries of the hand. Prior to arteriography of the hand a strong vasodilator was injected intra arterially. For this purpose $20 \mathrm{mg}$. Tolazoline hydrochloride ('Priscol') diluted in $20 \mathrm{ml}$ saline was used standardized (Janevski, (65)). Whenever the vasospastic symptoms were severe and clinically evident before intra-arterial injections of vasodilator and contrast medium, the hand was warmed by placing it in warm water for several minutes. It is important to emphasize that an organic occlusion on angiograms should be diagnosed if it persists until the end of the arterial phase of the series. The presence of direct and indirect collaterals is also considered a confirmary sign of occlusion.

The angiograms were routinely studied by the subtraction technique and were evaluated and graded separately for the presence of organic obstructive disease and functional vasospasm.

For this purpose the gradation described by Rösch was used (121) (Table IV.1).

Table IV.]:

Gradation of angiography disturbances (Rösch).

Obstructive disease in radial or ulnar artery:

grade 0 :normal

1 :moderate stenosis

2 :severe stenosis

3 :occlusion

Obstmetive disease in digital and palmar arteries:

grade 0 :no areas of stenosis or occlusion

1 :areas of stenosis and/or single total occlusion

2 :two or three occlusions

3 : four or more occlusions 
Vasospasm was graded as follows:

grade 0 :no vasospasm

1 :diffuse concentric narrowing of proper digital arteries

2 :no filling of proper digital arteries plus attenuation of common digital arteries

3 :no filling of common digital arteries plus attenuation of palmar arches

4 :no filling distal to the radial and ulnar arteries

In patients with ischaemic hand phenomena it is difficult to classify their complaints. In order to standardize the preoperative state, the patients were classified according to their handicap in normal daily life. The following gradation was introduced by the author.

Table IV.2:

Classification of the preoperative clinical state

0 : no symptoms

1: no symptoms if precautions taken

2: symptoms but not handicapped

3: handicapped in normal daily life

4: severe complaints, only simple routine tasks are possible

5: invalid

\section{IV.3 Results}

After evaluation the angiograms could be divided into two groups, one with and one without obstructive lesions. The second group with non-obstructive lesions could be subdivided in normal angiograms and angiograms showing vasospasm (Table IV.3, Fig. IV 1-3).

Table IV.3:

Angiographic signs

\begin{tabular}{lr} 
& N \\
Normal & 34 \\
Vasospasm & 31 \\
Obstructive lesions & 56 \\
\hline & 121 \\
\hline
\end{tabular}

In addition to these lesions a compression of the subclavian artery was found in the provocative position in seven of the 121 cases. Damage to the arterial wall was seen in one of them. In three of these cases obstructive lesions of digital arteries were found.

Table IV. 4 shows the angiographic signs in relation to the clinical diagnosis. The angiographic findings were classified as 'normal', vasospasm, mild and severe obstructions. 


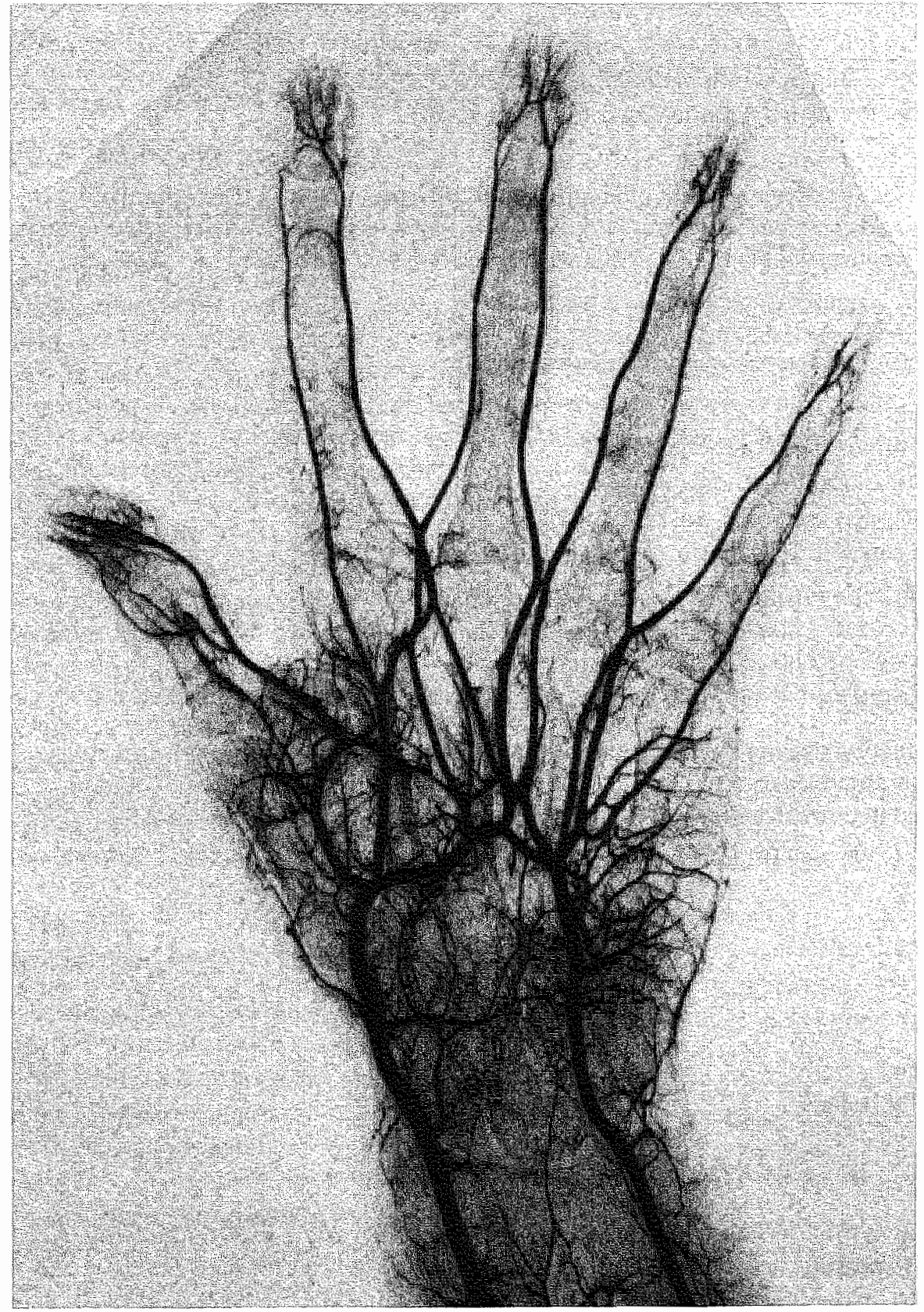

Figure IV.1

Normal anteriogran of the hand. 


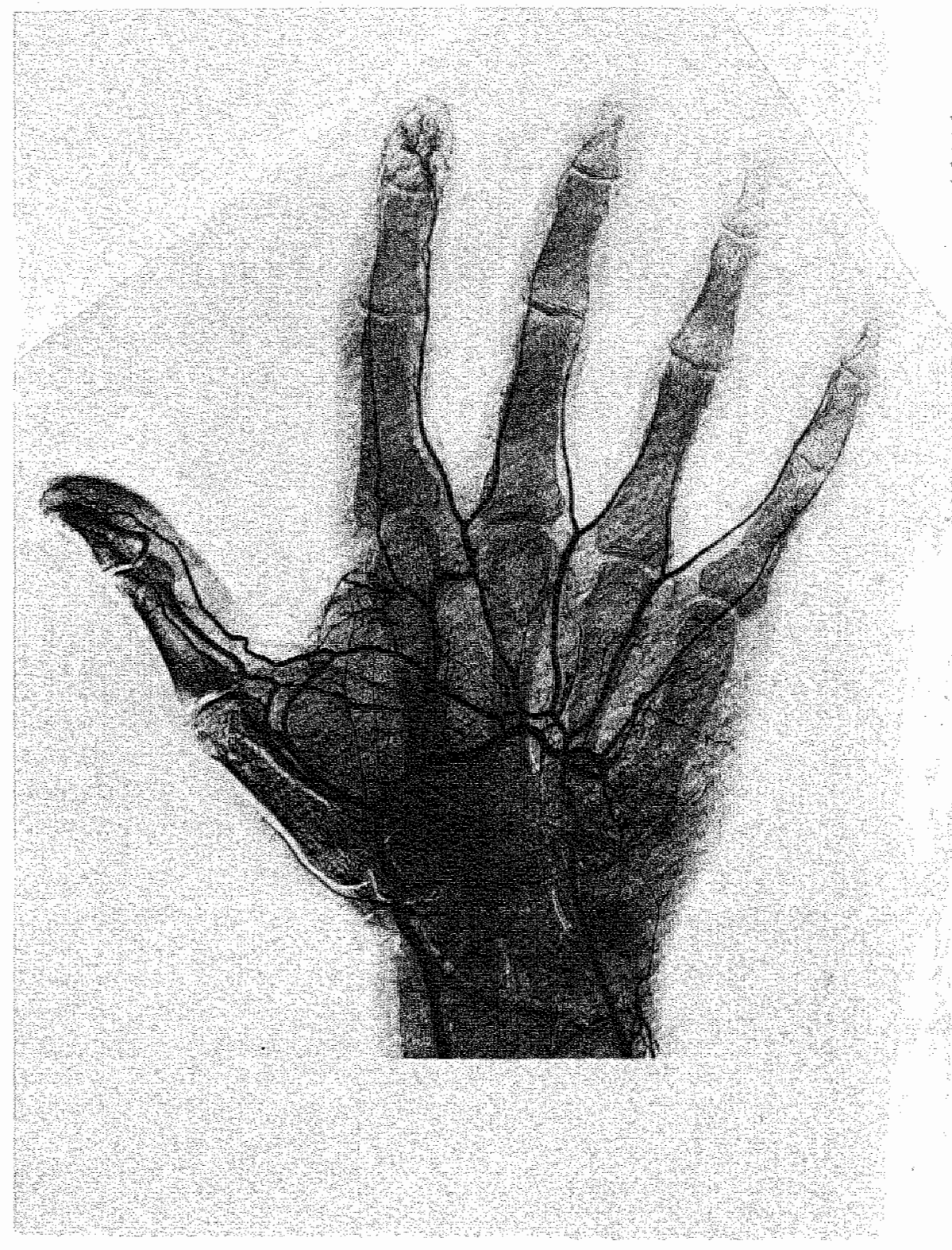

Figure IV.2

Arteriogram of the hand with vasospasm.

Diffuse concentric narrowing and tapering of proper digitall arteries in the third, fourth and fifth finger. 


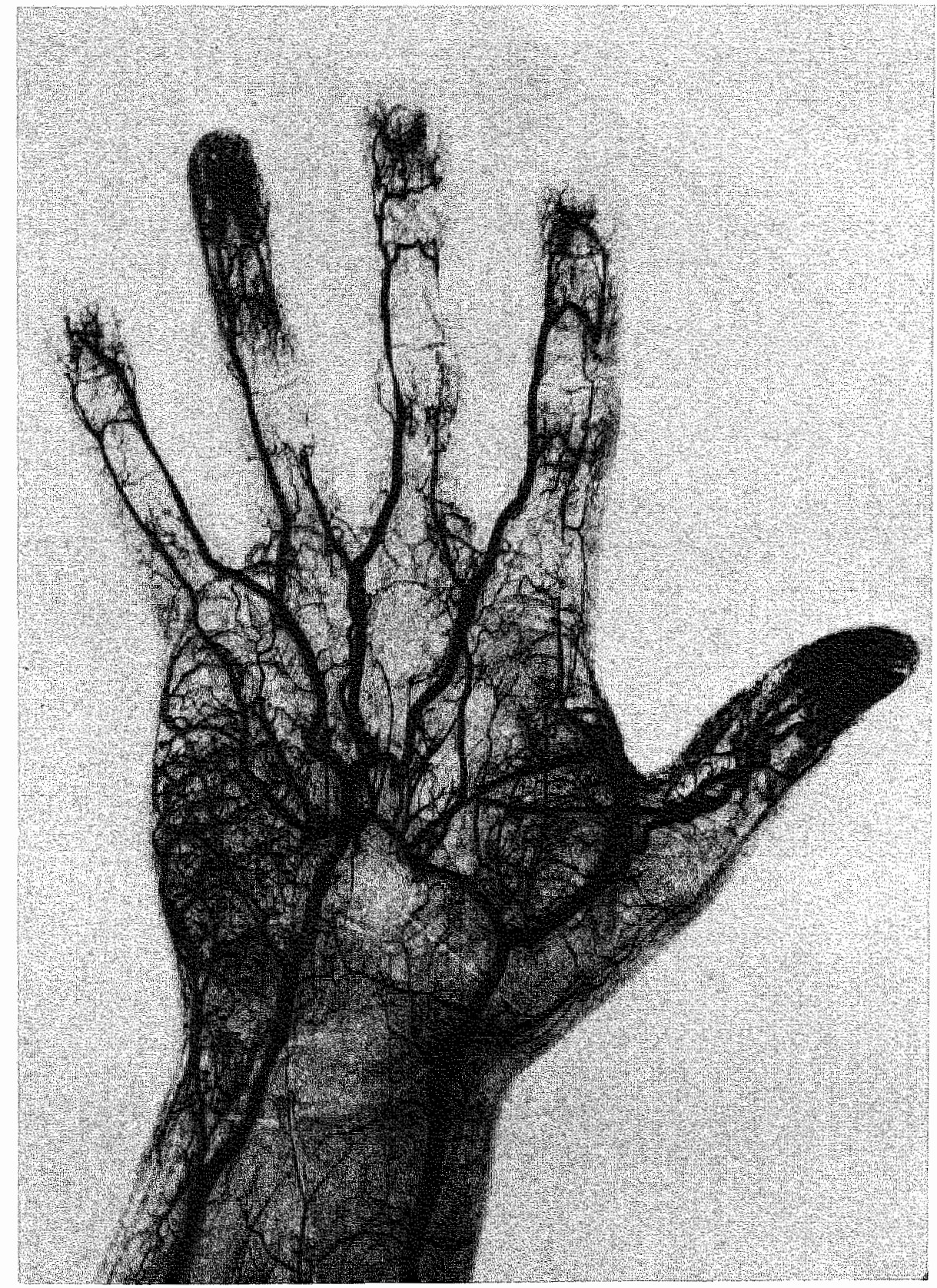

Figure IV.3

The angiogram demonstrates mul tiple occlusions in the second, third and fourth finger. 
Angiograms were classified as showing severe obstruction when three or more occlusions were found.

In patients with the clinical diagnosis of primary Raynaud's phenomenon a variety of angiographic disturbances were found.

In total $40 \%(28 / 70)$ were without pathological signs. In 30\%(25/70) various gradations of vasospasm were seen. Obstructive lesions, all classified as mild were found in $24 \%(17 / 70)$. The patients with the clinical diagnosis of secondary Raynaud's phenomenon nearly all, $80 \%(16 / 19)$ had obstructive lesions of the digital arteries which were of the severe type in $81 \%(13 / 16)$. In addition to obstructive lesions in finger arteries, an occluded ulnar artery was seen in 7 cases.

All patients with clinical symptoms of asphyxia had obstructive lesions in the arteries of the affected fingers. The majority were classified in the severe group $71 \%(15 / 21)$.

The angiographic signs found in patients with post-traumatic dystrophy were distributed over all groups although most were in the 'normal' or vasospastic group $82 \%(9 / 11)$.

\section{Table IV.4:}

Angiographic signs in relation to the clinical diagnosis. (Primary Raynaud's phenomenon (P.R.P.), secondary Raynaud's phenomenon (S.R.P.) and post-traumatic dystrophy (P.T.D.)).

Clinical diagnosis
P.R.P.
S.R.P.
Asphyxia
P.T.D.

Angiography

\begin{tabular}{llllll}
\hline 'normal' & 28 & 1 & - & 5 & 34 \\
vasospasm & 25 & 2 & - & 4 & 31 \\
obstruction, mild & 17 & 3 & 6 & 2 & 28 \\
obstruction, severe & - & 13 & 15 & - & 28 \\
\hline & 70 & 19 & 21 & 11 & 121
\end{tabular}

The preoperative clinical state of the affected extremities in relation to the angiographic disturbances are listed in table IV.5.

Many of the patients investigated $40 \%(48 / 121)$ were handicapped in normal daily life (preoperative state grade 3 (Table IV.2)). They are distributed over all different groups of angiographic disturbances, i.e. 50\% (17/34) in the 'normal' group, 35\% (11/31) of those with vasospasm, $32 \%(9 / 28)$ of those with mild and $39 \%(11 / 28)$ of those with severe obstruction.

In patients with fewer symptoms (grades 1 and 2 ) the percentages found were $9 \%(3 / 34)$ with 'normal' angiograms $32 \%$ (10/31) of those with vasospasm, and $21 \%$ $(6 / 28)$ of those with mild and $21 \%(6 / 28)$ of those with severe obstructive lesions. In patients with severe complaints (grades 4 and 5 ) the respective percentages found were $32 \%(14 / 34)$ of the 'normal' angiograms, $32 \%(10 / 31)$ of the vasospasm, $46 \%$ (13/28) of the mild and $39 \%(11 / 28)$ of the severe obstructive lesions. 
Table UV.

Preoperative clinical state of the affected extremity in relation to the angiographic singns.

\begin{tabular}{lcrrrrr}
\hline & \multicolumn{6}{c}{ Preoperative clinical state } \\
Angiography & 1 & 2 & 3 & 4 & 5 & \\
\hline 'normal" & 3 & - & 17 & 8 & 6 & 34 \\
vasaspasm & 5 & 5 & 11 & 8 & 2 & 31 \\
obstruction, mild & - & 6 & 9 & 10 & 3 & 28 \\
obstruction, severe & 2 & 4 & 11 & 4 & 7 & 28 \\
\hline & 10 & 15 & 48 & 30 & 18 & 121 \\
\hline
\end{tabular}

Table IV.6 shows gradation of vasospasm in relation to the preoperative clinical state. $77 \%$ (24/31) of the vasospastic disorders were grade 1. (diffuse concentric narrowing of proper digital arteries) and were divided over all severity scores. Only in $23 \%$

(7/31) was severe vasospasm found. No relation was seen between grade of vasospasm and grade of preoperative clinical state.

Table IV.6:

Grade of angiographic vasospasm in relation to the preoperative clinical state.

\begin{tabular}{rrrrrrr} 
& \multicolumn{7}{c}{ Preoperative clinical state } \\
& 1 & 2 & 3 & 4 & 5 & \\
\hline grade of vasospasm 1 & 2 & 4 & 9 & 7 & 2 & 24 \\
2 & 3 & 1 & - & - & - & 4 \\
3 & - & - & 2 & - & - & 2 \\
4 & - & - & - & 1 & - & 1 \\
\hline & 5 & 5 & 11 & 8 & 2 & 31
\end{tabular}

Table IV 7 presents the grade of obstruction in relation to the preoperative state. In $36 \%(20 / 56)$ of the patients a preoperative state grade 3 was found distributed over all groups of obstructions grades. Thirty two per cent (7/22) had grade 1 obstruction, $24 \%$ (4/1.7) grade 2 and $53 \%(9 / 17)$ had grade 3 obstruction.

The patients with fewer complaints (preoperative state grades 1 and 2 ) were found in $18 \%$ (4/22) of those with obstruction grade 1, 24\% (4/17) of those with grade 2 and $24 \%$ (4/17) of those with grade 3 obstruction.

The patients with severe complaints (grades 4 and 5 ) were found in all groups: $50 \%$ (11/22) in obstruction grade $1,53 \%(9 / 17)$ in grade 2 and $23 \%(4 / 17)$ of those with grade 3 obstruction. 


\section{Table IV.7:}

Grade of angiographic obstruction in relation to preoperative clinical state.

\begin{tabular}{rrrrrrr}
\hline & \multicolumn{7}{c}{ Preoperative clinical state } \\
\hline grade of obstruction 1 & 1 & 2 & 3 & 4 & 5 & \\
2 & - & 4 & 7 & 10 & 1 & 22 \\
3 & 1 & 3 & 4 & 4 & 5 & 17 \\
\hline & 2 & 10 & 20 & 14 & 10 & 56
\end{tabular}

The angiographic signs in patients with primary Raynaud's phenomenon in relation to the severity of the subjective complaints are presented in table IV.8.

Many of the patients $43 \%$ (30/70) with primary Raynaud's phenomenon were

handicapped in daily life. The percentages of patients with few complaints (grades 1 and 2) were found respectively in $11 \%(3 / 28)$ of the 'normal', $40 \%(10 / 25)$ of the vasospastic and in $29 \%(5 / 17)$ of the group with obstructive lesions in the angiograms.

The percentage of patients with severe complaints (grades 4 and 5) are found respectively in $32 \%(9 / 28)$ of the 'normal', $24 \%$ (6/25) of those with vasospasm, and $41 \%(7 / 17)$ of the group with obstructive lesions in the angiograms.

Table IV.8:

Angiographic sign in relation to preoperative clinical state in patients with primary Raynaud's phenomenon.

\begin{tabular}{lcccccc}
\hline & \multicolumn{7}{c}{ Preoperative clinical state } \\
Angiography & 1 & 2 & 3 & 4 & 5 & \\
\hline 'normal' & 3 & - & 16 & 7 & 2 & 28 \\
vasospasm & 5 & 5 & 9 & 5 & 1 & 25 \\
obstruction, mild & - & 5 & 5 & 6 & 1 & 17 \\
\hline & 8 & 10 & 30 & 18 & 4 & 70
\end{tabular}

\section{IV.4 Discussion}

In this study no correlation was found between angiographic abnormalities and clinical diagnosis. This is in accordance with the study presented by Kent (72).

A limitation of angiography is that the demonstration of an occluded artery can be related to a large number of conditions. Occluded arteries are described in patients with secondary Raynaud's phenomenon, asphyxia and post-traumatic dystrophy (table IV.4). Although the arteries in primary Raynaud's phenomenon are normal by definition, digital artery occlusion has been demonstrated in several cases. Many authors have confirmed the presence of peripheral occlusions in patients with a primary Raynaud's phenomenon $(18,21,72,115,125)$. The explanation is, that due to prolonged symptoms changes in the arterial wall may lead to occlusion. An other possibility is the devellopment of progressive 
systemic sclerosis (P.S.S.) in these patients on the long-term. In approximately $30 \%$ to $70 \%$ of patients with P.S.S. Raynaud's phenomenon is the first clinical symptom (17, 37). It ever may be the only manifestation of P.S.S. for many years (144).

Janevsk (65) described the specific signs of obstructive lesions found in a variety of occlusive diseases. It is beyond the scope of this thesis to discuss these findings in detail. In patients with primary Raynaud's phenomenon Bergan (18), Rösch (121) and Burnstingl (21) all concluded that arteriographic signs were related to the severity of the disease.

Most patients in this study with a clinical diagnosis of primary Raynaud's phenomenon had at subjective preoperative state grade 3 , but were divided among all sorts of angiographic disturbances (table IV.8).

In patients with fewer complaints (grades 1 and 2) the highest percentage of the vasospastic angiographic disturbances was found to be $40 \%(10 / 25)$, as against $11 \%(3 / 28)$ in 'normal" and 29\% (5/17) in the obstructive group. In the patients with severe complaints (grades 4 and 5 ) small differences were found in the percentages of angiographic signs, with $32 \%(9 / 28)$ among the "normal", $24 \%(6 / 25)$ of those with vasospasm and $41 \%(7 / 17)$ of those with obstructive lesions. Although the presented data are limited there seems to be no clear relation, between the severity of complaints and the degree of angiographic pathology in patients with primary Raynaud"s phenomenon.

A part from the clinical diagnosis no relation was found between severity of vasospasm and preoperatve symptoms (Table IV.6). In 77\% of cases a modlerate vasospasm was found, distributed over all severity scores. The explanation for the low percentage $(23 \%)$ of severe vasospasm might be the technique used for angiography of the upper extremity. In particular warming the hand by placing it in warm water for several minutes before intraarterial injections of contrast medium in patients with clinically evident vasospasm, might be responsible for the low grade of vasospasm found.

The grade of obstruction was atso not related to the severity of subjective symptoms. (Table IV.7).

Compression of the subclavian artery in the provocative position was found in seven cases but only in three of them were obstructive lesions of the finger arteries found. The clinical diagnosis in two patients was asphyxia and one had progressive systemic sclerosis (P.S.S.). In the patient with P.S.S. the underlying disease was believed to be the source of the obstructive lesions in the digital arteries. It seems that the use of functional angiography in assessing patients with ischaemic hand phenomena is of minor importance. Only in patients with the clinical of diagnosis asphyxia it is indicated to exclude a thoracic outlet compression syndrome or aneurysm as source of peripheral nicro emboli.

\section{IV .5 Conclusions}

Routine angiography has only limited value in patients with ischaemic hand phenomena. Besides that the angiographic changes are non-specific and do not correlate with the clinical diagnosis, the procedure has no value in classifying the complaints objectively. The only indication left is in patients with the clinical diagnosis of asphyxia when operable vascular lesions are suspected in the aortic arch or in its branches to the upper extremity from which micro emboli might arise. 


\section{Chapter V}

\section{Operative techniques}

\section{V.1. Technique for thoracodorsal sympathectomy 'en bloc'}

In most patients analysed in this study a paravertebral skin incision with muscle division has been used. Because of the postoperative scar pain, especially on the long term the skin incision has been changed from paravertebral to midline.

The recently applied technique will be described.

The patient is placed in a prone position. The arm and shoulder of the affected side are kept in forward rotation to displace the scapula as far from the midline as possible (Fig. V.1).

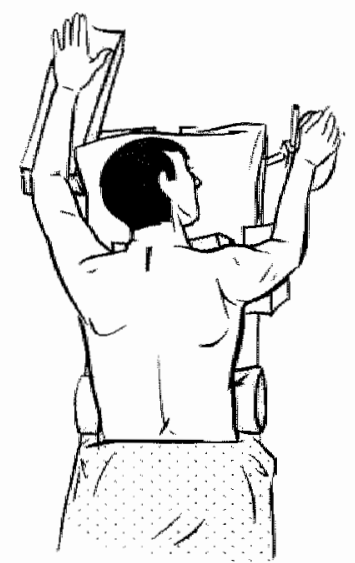

Figure V.1:

Patient in prone position. Right arm on forward rotation

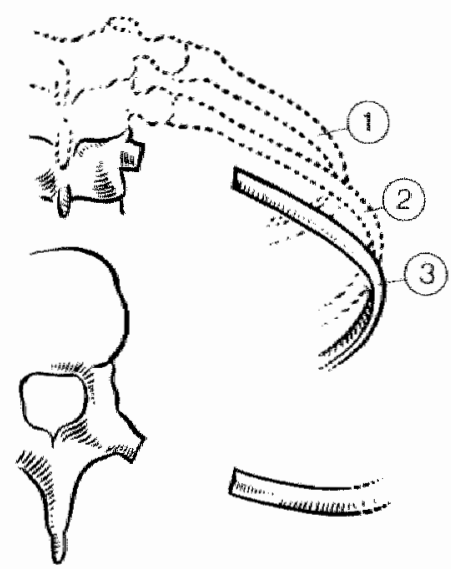

Figure V 2:

Third rib with its articulation with and pirt of transwerse process removed.

(abowe): posterior vicw, (bellow): cross sectioned view

A midline skin incision is made from the spinous process of the first thoracic vertebra down to the fourth thoracic vertebra. The insertions of the deep fascia and the trapezius muscle are divided from the spinous process. The rhomboid muscle is severed from its insertion, the posterior superior serratus muscle appearing in the upper corner of the wound. This exposes the erector spinae muscle. The next step is counting the ribs to identify the third rib. If there is any doubt, the ribs can be identified by $x$-ray examination. The attachments to the third rib are then divided.

Consequently the tips of the transverse process can be felt. The articulation of the third rib with the transverse process of the vertebra is identified. The pleura is now depressed with a finger and the third transverse process is removed from the arch of its vertebra. The procedure is continued by removing $4-5 \mathrm{~cm}$ of the third rib as well as its articulation with the vertebral body and transverse process (Fig. V.2). This procedure exposes the parietal 
pleura, to which the intercostal nerves, sympathetic chain and blood vessels are adherent. (Fig. V.3).

If this exposure does not give enough view, the same procedure can be applied at the level of the second rib and transwerse process.

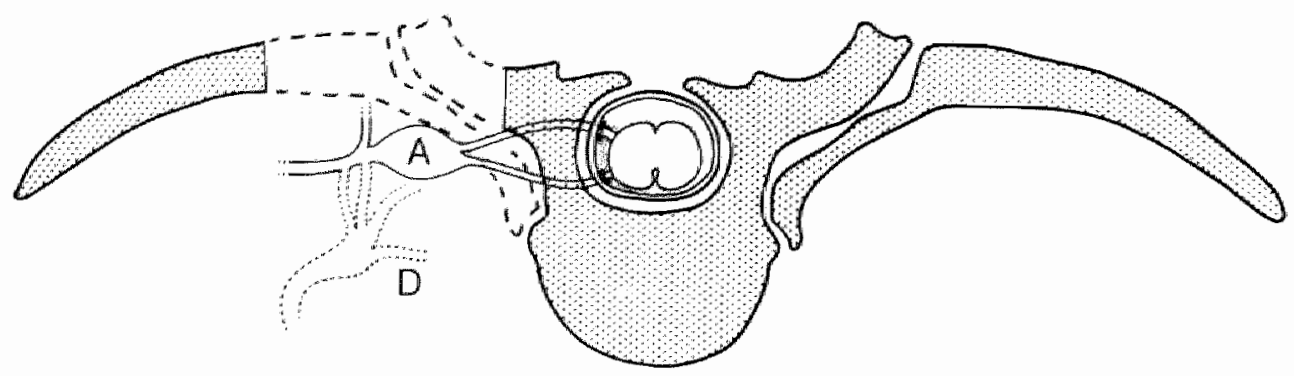

Figure V.3:

Crass section at the level of the third thoracic vertebrae. After resection of part of the third rib and its articulation with the third thoracic wertebrate and its transverse process a clear view on the intercostal nerve (A) and symparhectic ganglion (D) is achieved.

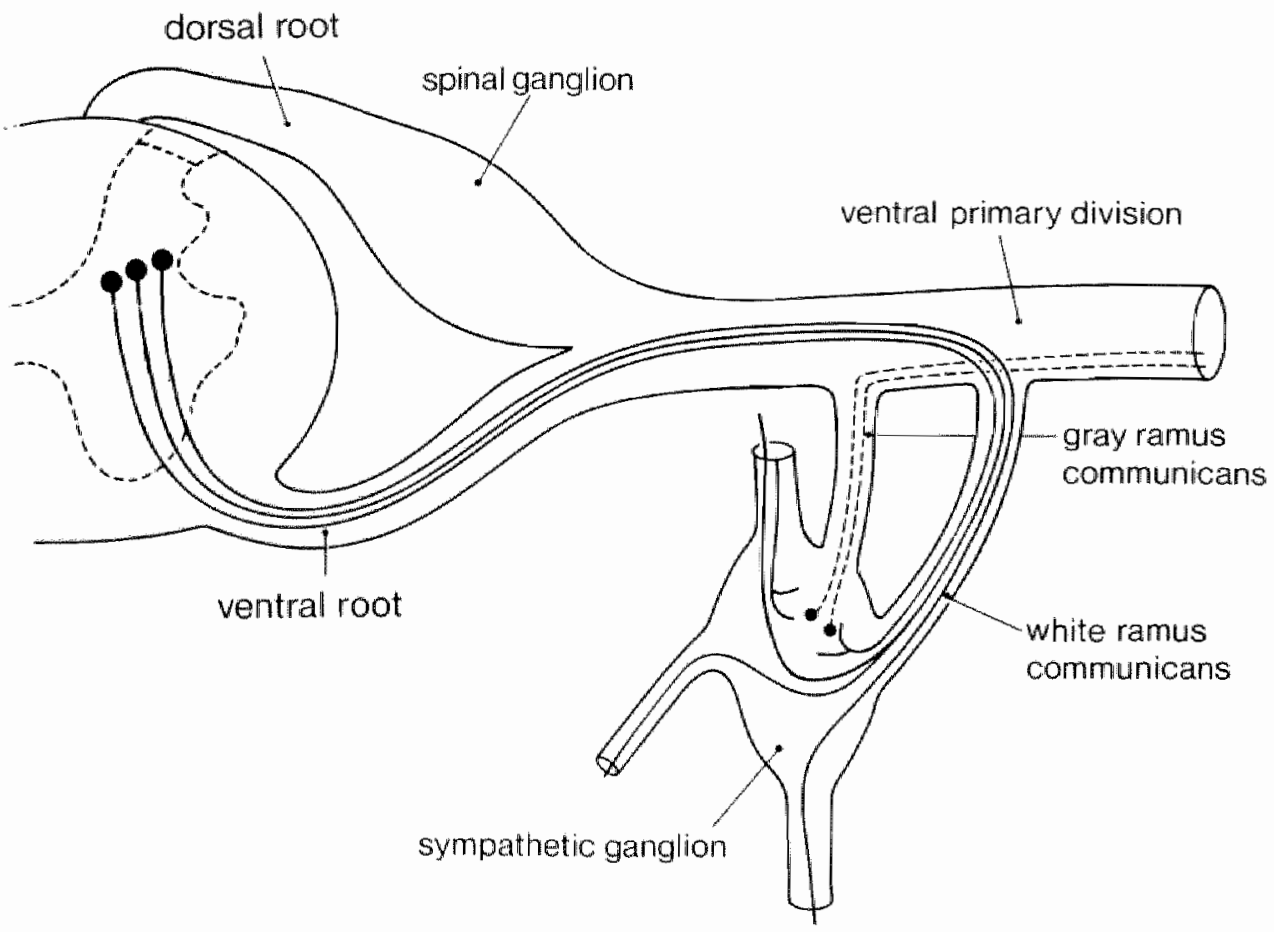

Figure V.4:

Schematic representation of the course of sympathetic fibers in relation to the intercostal nerve. 
Consequently the second intercostal nerve is identified and followed in the direction of the spine. By blunt dissection the posterior ramus of the intercostal nerve is identified and divided. The spinal ganglion will become visible by traction on the intercostal nerve. The dura mater must be gently pushed medially by blunt preparation. A nerve hook is placed between the wentral and dorsal roots, by which the spinal ganglion is pulled out of the dura mater and divided medially (Fig. V.4). This manoeuvre is sometimes followed by a small cerebrospinal fluid leakage which stops spontaneously.

The ventral root is also divided. The sympathetic chain is identified and cut below the third sympathetic ganglion. Cranially the sympathetic chain is divided above the first thoracic sympathetic ganglion. When the first thoracic sympathetic ganglion is found to be fused with the stellate ganglion (inferior cervical ganglion), the lowest one-third of this ganglion is resected.

The lateral borders of the 'en bloc' resection are the second and third intercostal nerves which are resected $4 \mathrm{~cm}$ lateral to the vertebrae. Finally the intercostal nerves, sympathetic ganglia and surrouding connective tissue can be taken out separately from the pleura. In this way the intrathoracic nerve described by Kuntz is inevitably interrupted (Fig. V.5. and Fig. V.6). Most 'en bloc' resections are possible without

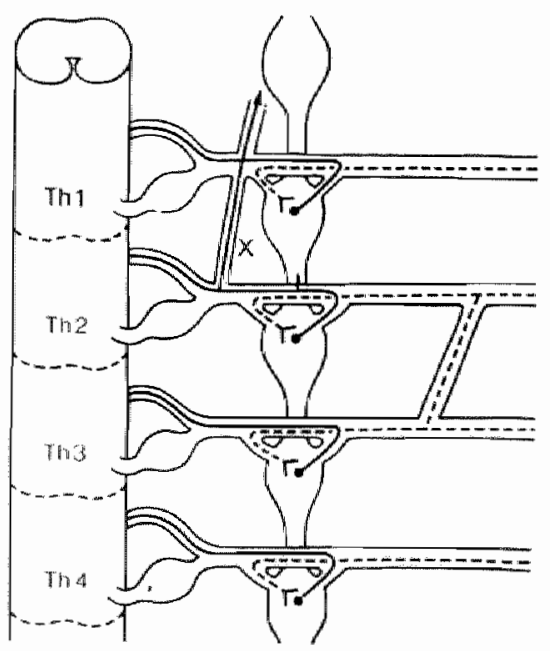

Figure V.5:

Schematic representation of the upper thoracic sympathetic chain in relation to the spinal hervous system. (posterior view) $(x)$ Intrathoracic nerve described by Kuntz.

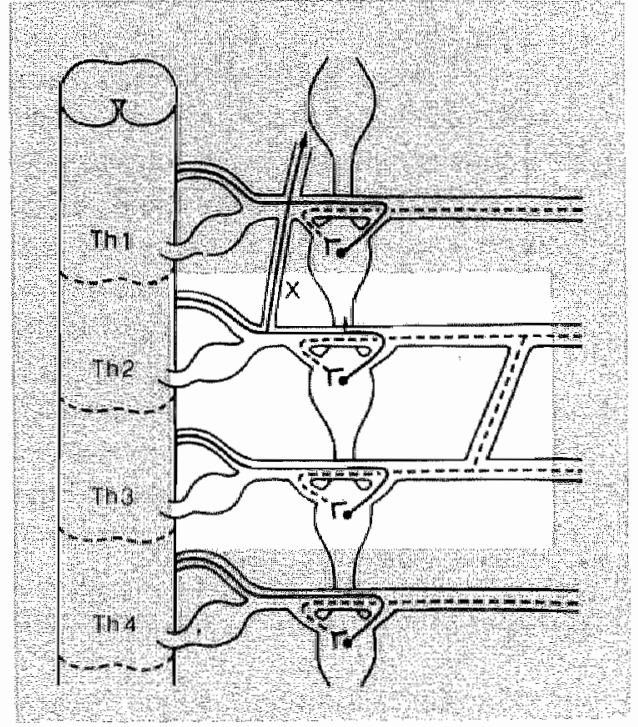

Figure V.6:

Schematic outline of the operative procedure (posterior view).

damaging the pleura. Sometimes the pleura is opened especially in cases of a resympathectomy. With or without damaging the pleura, a redon suction drain is left in place and the wound is closed in layers with resolvable sutures. 


\section{V.2. Technique for re-sympathectomy}

The patient is placed in the same position and the same dorsal approach as described in V.1. is used (Fig. V.1.). After resection of a part of the transverse process and the third rib with its articulation with the third vertebra a clear view of the intercostal nerves is achieved (Fig. V.3). The same procedure is followed to disconnect the second and third intercostal nerves. The high thoracic sympathetic ganglia would already have been resected in the previous operation (Fig. V.7). Finally the intercostal nerves and surrounding connective tissue can be taken out. The intrathoracic nerve described by Kuntz will also be resected in this way (Fig. V.8).

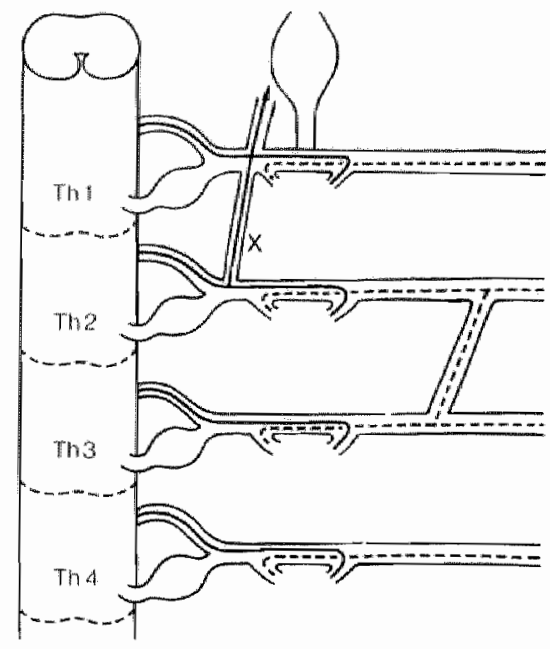

Figure V.7:

Schenatic representation of the anatonical. situation after resection of sympathetic ganglia only (posterior view).

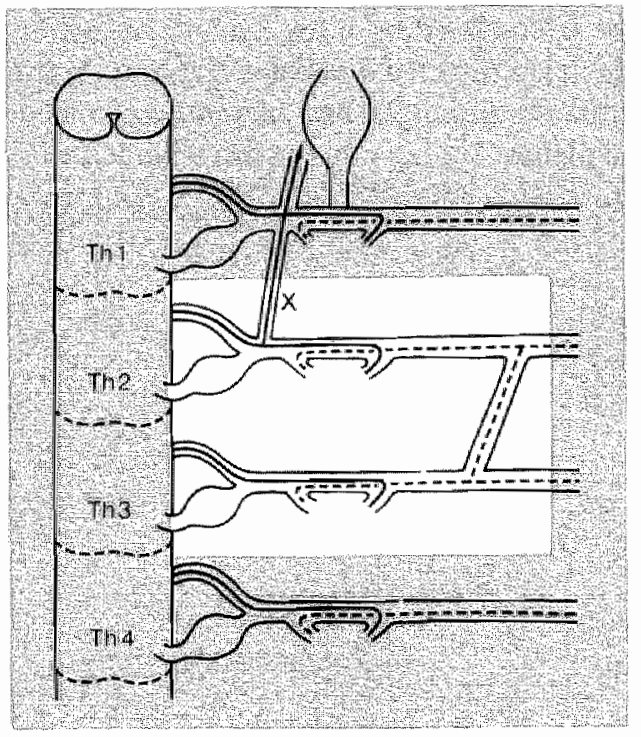

Figure V.8:

Schematic oulline of the operative procedure for a re-sympathectomy (posterior view). 


\section{Chapter VI}

\section{Anatomical study}

\section{Abstract}

Upon studying microscopically and macroscopically 18 resection preparations of upper thoracic sympathectomies it is clear that the variability in the anatomy of the sympathetic nervous system in connection with the spinal nervous system is higher than has always been described. A fine network of smaller and larger nerve bundles was found which connect the sympathetic and spinal nerve systems. Light microscopical perikarya were identified in many nerve bundles. These findings have an important impact on the concept of the effectiveness of thoracic sympathectomy.

\section{VI.1 Introduction}

The high percentage of recurrences of vasomotor activity in the hand after thoracic sympathectomy has been an unsolved problem for many years. To solve this problem operative procedures have been modified several times. At the beginning of this century Leriche (92) introduced the periaterial sympathectomy. This operation was based on the idea that sympathetic fibres reached the peripheral vessels by way of the arterial adventitia. The clinical results of this operation were not satisfying and the underlying concept proved to be anatomically wrong. The method was abandoned.

Brüning and Stahl (24) described in 1924 the extirpation of the cervicothoracic ganglion. The anatomical principle behind this operation was that postganglionic fibres reached the brachial plexus by way of several rami of the cervicothoracic ganglion.

A serious drawback to this procedure, however, was the frequent postoperative occurrence of a Horner's syndrome. Telford (145) and Smithwick (131) devised a so-called preganglionic sympathectomy. They presumed that the second thoracic medullary segment was the highest level from which preganglionic fibres originated. The operation consistsed of the interruption of the preganglionic fibres of the second and third thoracic segment in addition to severing the sympathetic trunk below the third thoracic ganglion. Short successes were mentioned but the operation did not accomplish total elimination of the vasomotor activity.

In $1927 \mathrm{Kuntz}$ (78) described an intrathoracic nerve connecting the second intercostal nerve and the first thoracic spinal nerve along which sympathetic fibres could reach the brachial plexus, thus bypassing the sympathetic trunk. Lemmens ( 88 ) conceived a mode of sympathectomy in which not only the sympathetic ganglia but also parts of the second and third intercostal nerves and their surrounding structures were removed. The second and third intercostal nerves were removed, together with their ventral and dorsal roots and their spinal ganglion in order to interrupt the preganglionic fibres as close as possible to their origins in the central nerve system. This operation method provided a total elimination of the sympathetic nerve system to the arm. 


\section{VI.2 Methods and material}

The sympathetic trunk is exposed through a thoracodorsal incision. Relevant structures are marked with microclips followed by total resection.

Eighteen resection preparations were investigated in the laboratory. The fresh preparation was stained in toto for acetylcholinesterase according to Baljet and Drukker (12). After incubation the peripheral nerves appeared brown, thus facilitating the dissection. During the preparation the nerves were reincubated, so that the deeper peripheral nerves could stain further. After clearing the preparation in glycerine it was ready for study. Using a stereodissecting microscope nervous tissue was further dissected. Consequently microscopic sections were made of branches of the second intercostal nerve and of most structures of unknown origin. They were stained with toluidine blue.

\section{VI.3 Results}

As noted while preparing and studying the preparations the great variability in the anatomy was striking (Figs. VI.1 and VI.2), particularly the way in which the second intercostal nerve gave off its branches. A classification according to number and size of the branches has been made: large meaning a branch with a diameter of approximately onefourth of that of the intercostal nerve; middle meaning a branch with a diamerer of approximately one-eighth of that of the intercostal nerve; and small meaning a diameter of approximately one-sixteenth of that of the intercostal nerve (Table VI.1). In microscopic sections of these branches perikarya were identifiable.

There was considerably less variability in the anatomy of the third intercostal nerve. An intermediate branch travelling to the second intercostal nerve was found once. In about half of the cases a few microscopical branches were seen, but no such branches were found in the remainder. 

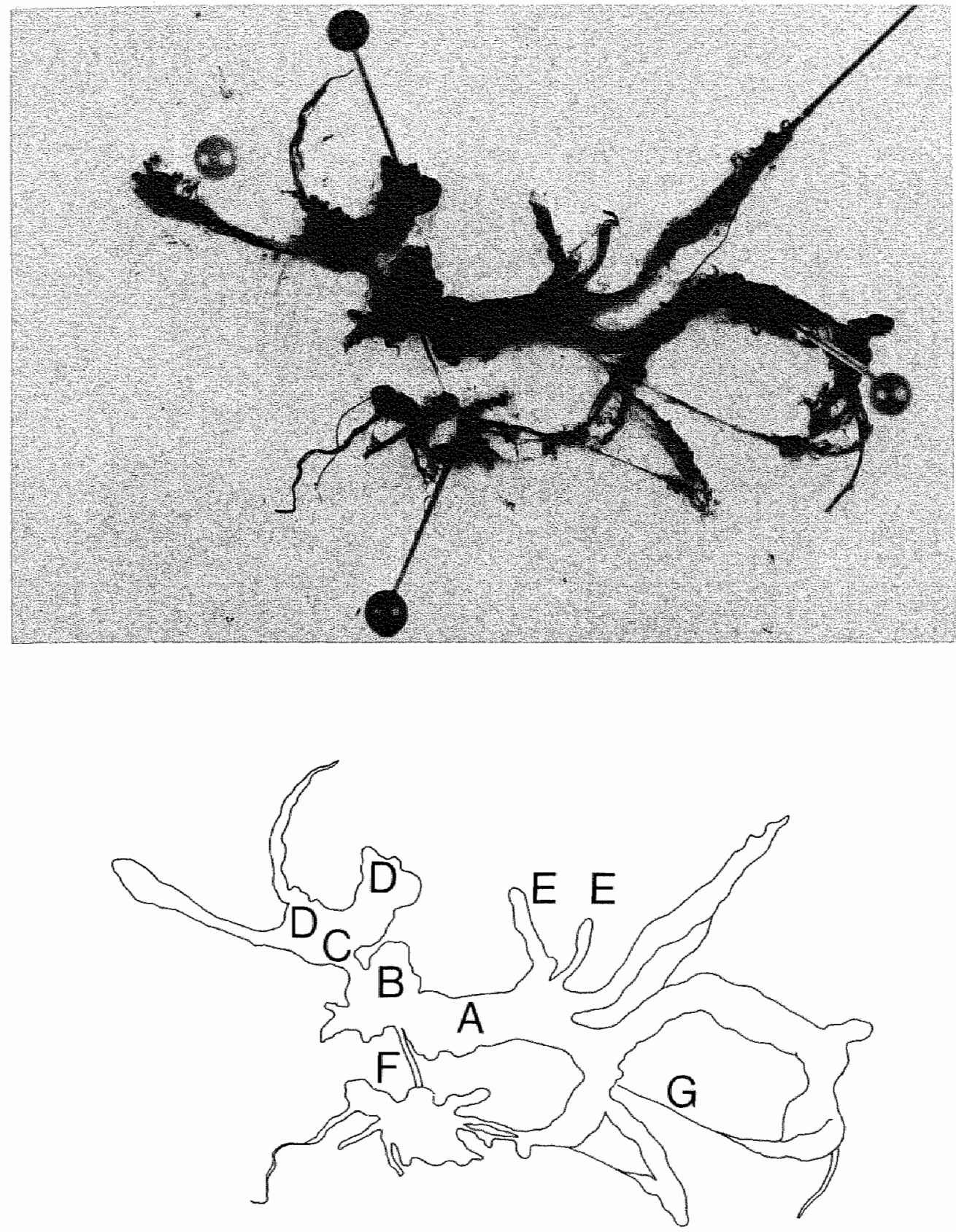

Figure VI.I

Network of perve bundles in relation to the second intercostal nerve and the sympathetic ganglia; $(A)$ second intercostal nerve; (B) spinal ganglion; (C) rami communicantes; (D) sympathetic ganglia; (E) large branch; (F) middle branch; (G) small branch. 

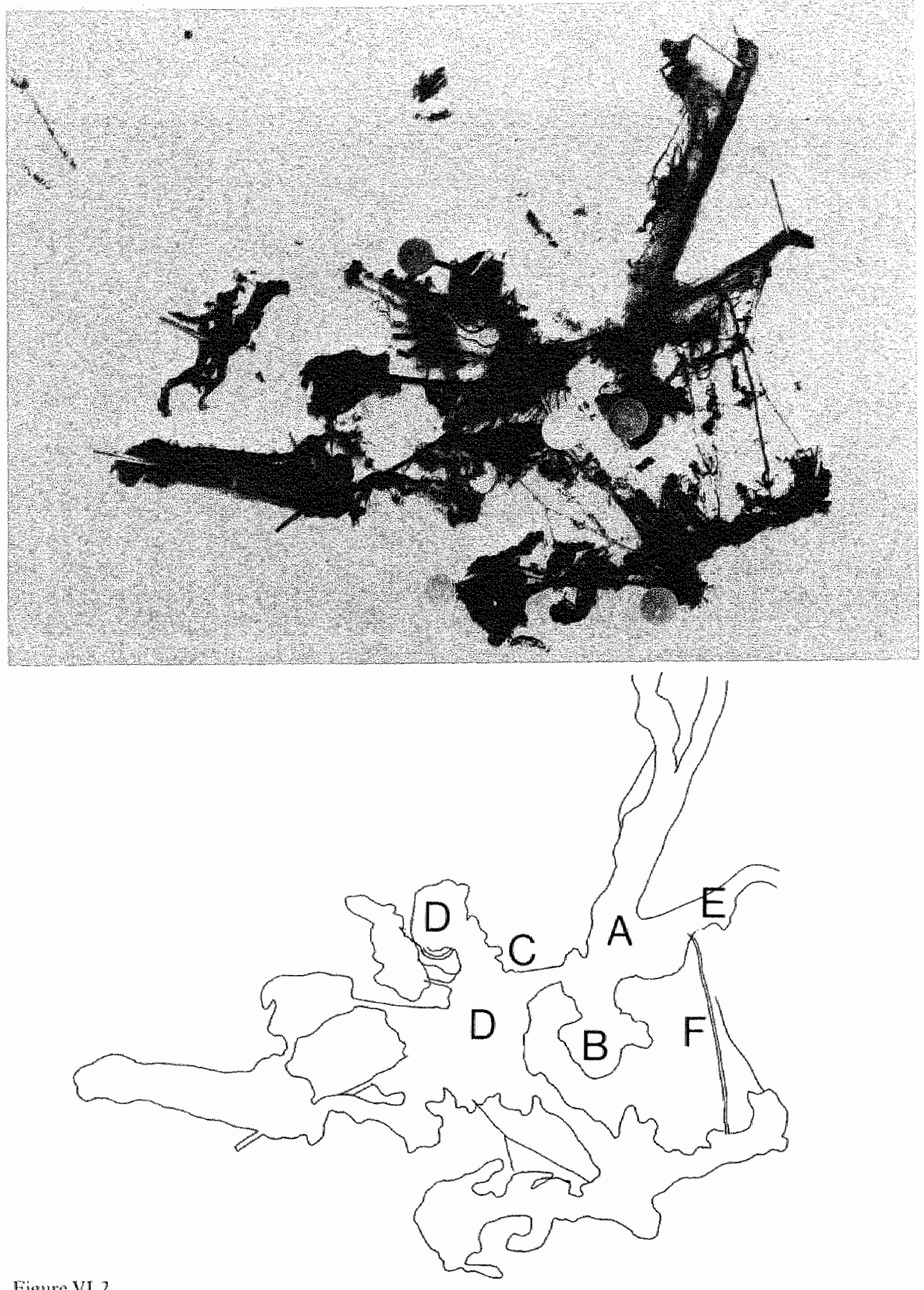

Figure VI.2

Nework of nerve bundles in relation to the second intercostal nerve and the sympathtic ganglia; (A) second intercostal nerve; (B) spinal ganglion; (C) rami communicantes; (D) sympathetic ganglia; (E) large branch; (F) naddle branch. 
Table VI.1

Number of branches of IIe intercostal nerve

\begin{tabular}{lllll}
\hline Patient & Large & Middle & Small & Microsc. \\
\hline 1 & - & 7 & - & Multiple \\
2 & - & 2 & - & Multiple \\
3 & - & 1 & - & Some \\
4 & - & 2 & - & Multiple \\
5 & 2 & - & - & Some \\
6 & - & - & - & Some \\
7 & - & - & 6 & Some \\
8 & - & 1 & - & Some \\
9 & - & 2 & - & Some \\
10 & 1 & - & - & Some \\
11 & - & 1 & 1 & Some \\
12 & 3 & - & - & Multiple \\
13 & - & - & - & Multiple \\
14 & 2 & - & - & Multiple \\
15 & 1 & - & - & Multiple \\
16 & - & 1 & - & Multiple \\
17 & - & 4 & - & Multiple \\
18 & 2 & - & - & Multiple \\
\hline
\end{tabular}

The mutual connections between the sympathetic ganglia consisted of one to three bundles of fibres. Branches of these connections extending into the surrounding tissue were found in two preparations. In all preparations a sympathetic ganglion could clearly be distinguished and it had connections with the second intercostal nerve by way of communicating rami. Apart from these communicating rami, a few branches from the ganglion into the surrounding tissue were seen in two preparations (Fig. VI.3). 

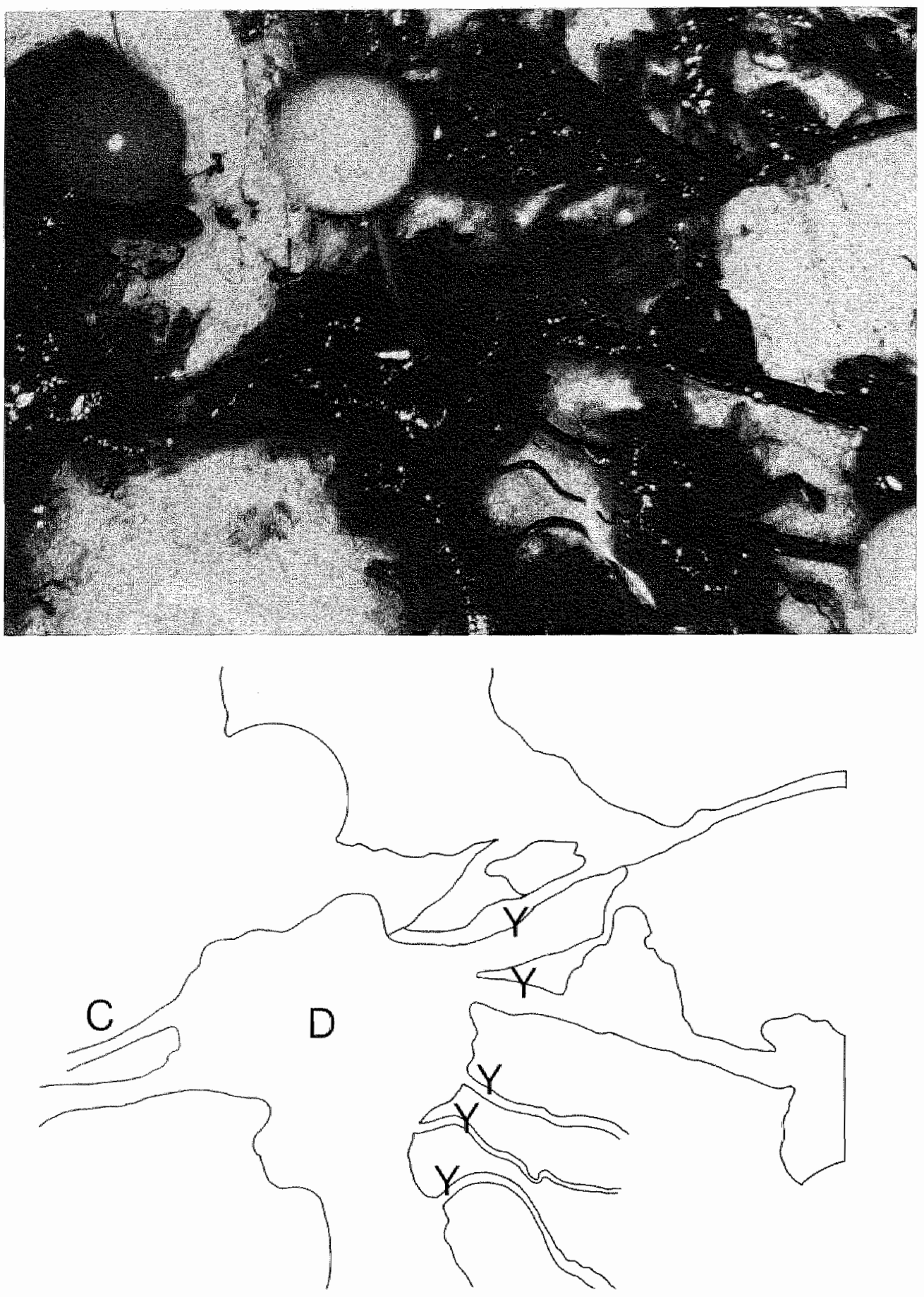

Figure VI.3

Sympathetic ganghia (D) with rami communicantes (C) and several branches to surrounding tissue ( $Y$ ). 

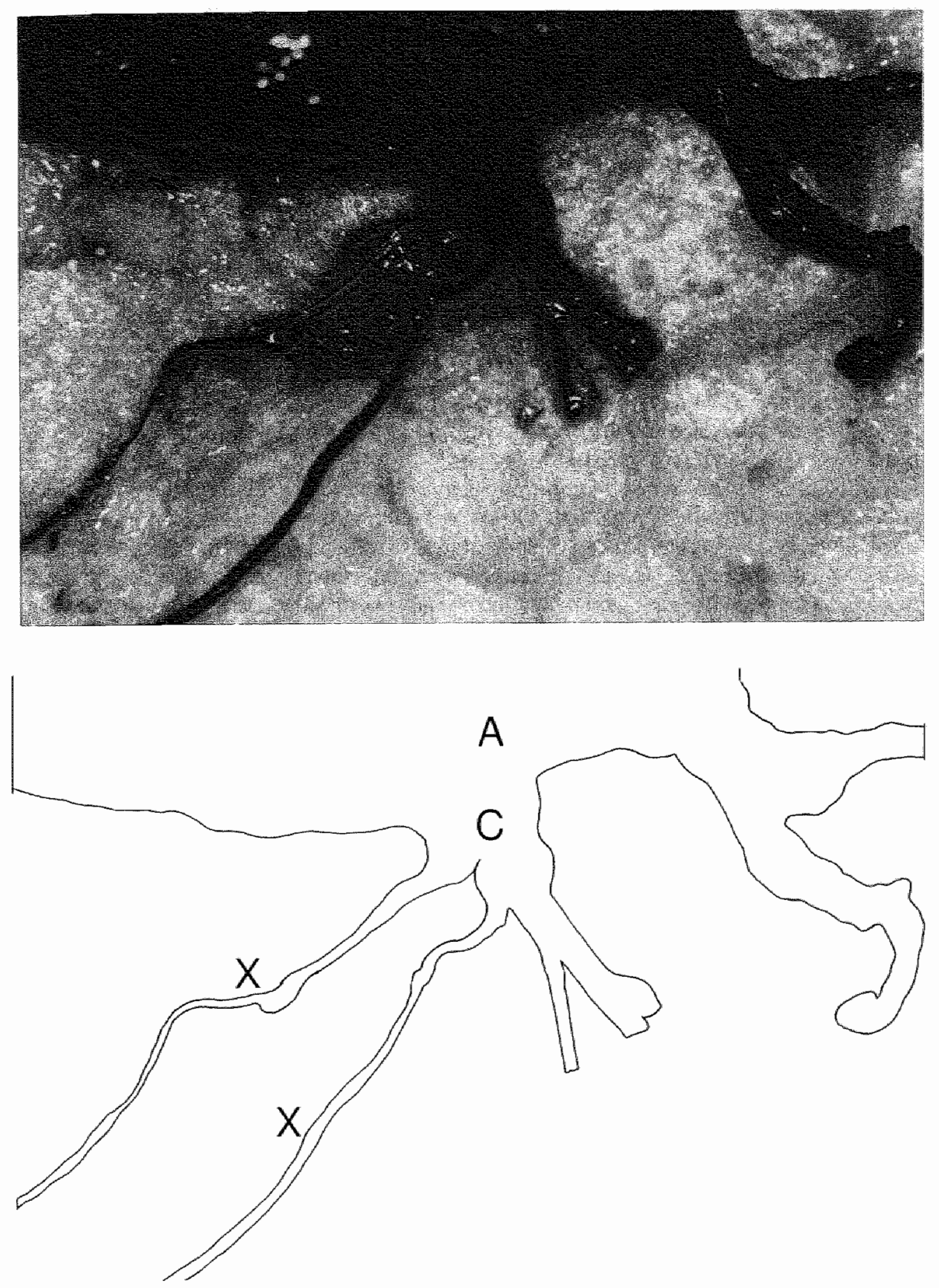

Figure VI.4

Rami comminicantes (C) with several branches to surrounding tissue (X). (A) 2nd intercostal nerve. 
The number of communicating rami connecting the second intercostal nerve and the second sympathetic thoracic ganglion was also subject to variation. They consisted either of one thick bundle or of a number of small bundles. In two preparations branches from the communicating rami could be traced centimeters into the surrounding tissue. They did not communicate with the second or third intercostal nerves nor with the first, second, or third sympathetic ganglia (Fig. VI.4).

\section{VI.4 Discussion}

The variability and the fine structure of the sympathetic nervous system have not yet been fully described. Mitchell (104) and Pick (112) described the autonomic nervous system using the state of the art at that time and their own observations. According to their studies and others it is known that the second thoracic segment is of importance for the sympathetic innervation of the $\operatorname{arm}(9,47,115,156)$. The variability of the high thoracic sympathetic nerve system is much greater than originally thought as proven in the present study. The number, size and direction of the branches originating from the second intercostal nerve are highly variable.

In 1927 Kuntz (78) described an intrathoracic nerve connecting Th. II and Th. I trough which it was possible for sympathetic fibres to reach the brachial plexus without passing through the sympathetic trunk. In the preparations studied this intrathoracic nerve of Kuntz was identified, and besides this nerve, many additional branches from the second thoracic nerve travelling to the brachial plexus and surrounding tissue were seen. On the basis of these observations the existence of several bypassing nerve routes is highly probable. Microscopical studies of those branches revealed mostly perikarya which appeared to be sympathetic ganglion cells. The presence of intermediary ganglia in the communicating rami and spinal nerves has already been described by Monro (105). Apparently these perikarya and intermediate ganglia were present in several locations of the upper thoracic level. New nerve fibres can sprout from perikarya, and thus form a potential source of reinnervation should sympathectomy be carried out without removing them.

With regard to the 3 rd intercostal nerve there appeared to be considerably fewer variations in anatomical structure. Except for a few microscopical branches the basic pattern was uniform.

The mutual connection between the sympathetic ganglia was consituted by one single or several bundles of fibres; this has already been described by Pick and Sheehan in 1946 (111). Aside from these bundles in a few preparations small and sometimes microscopical branches arising from the sympathetic trunk were noted, which travelled neither to nearby sympathetic ganglia nor to the second or third intercostal nerves. The above findings indicate other possible routes by way of which sympathetic fibres might reach the brachial plexus or extend directly into other structures. The anatomical variations of the rami communicantes in relation to the spinal nerves were pointed out by Pick in 1946 (111). Dass (33) described the connections between the communicating rami and the ventral and dorsal roots of the spinal nerves. These variations were confirmed in the present study, branches from rami communicantes which joined neither the sympathetic ganglia nor the second or third thoracic nerve were observed in a few cases. These unconnected sympathetic fibres constituted alternative routes to the brachial plexus or internal organs. 


\section{VI.5 Conclusion}

The variation in the anatomy of the upper thoracic sympathetic nervous system in relation to the spinal nervous system is much greater than has been described thus far, and there is a network of a few or several nerve bundles with various diameters. In a large number of these nerve bundles perikarya are found. Consequently there is the possibility that in a sympathectomy aimed at the interruption of all vasomotor and sudomotor impulses to the arm some tiny fibres are left intact and these are able to take over the function of the resected nerve bundles. Furthermore, perikarya can form nerve sprouts which take up contact with the decentralized axis and grow out along them.

With this new knowledge of the upper thoracic sympathetic nervous system in mind, one can question whether a permanent, complete interruption of all sympathetic fibres to the arm can be accomplished by thoracic sympathectomy.

\section{Acknowledgements}

This paper has been published in the Journal of Surgical Research.

Rhede van der Kloot E.J.H., Drukker J., Lemnens H.A.J., Greep J.M.

The high thoracic sympathetic nerve system. Its anatomic wariability.

Journal of Surgical Research 1986; 40:112 



\section{Chapter VII}

\section{Results of the thoracodorsal sympathectomy 'en bloc'}

In this chapter the results are presented of the T.D.S." en bloc' as a 'primary' operation.

\section{1 Patients and methods}

A total of 109 operations in 78 patients ( 31 bilateral procedures) were analysed (Table III.2). The operation was performed for a variety of indications of which five groups could be distinguished (Fig. III.1).

\section{Primary Raynaud's phenomenon}

A total of 53 procedures were performed on 32 patients ( 20 female, 12 male, 21 patients with bilateral procedures). The mean age in this group was 38 years (range 22-65). All patients were classified as having a primary Raynaud's phenomenon. The diagnosis was based on the criteria described in Chapter III. All patients had not responded successfully to conservative treatment.

\section{Secondary Raynaud's phenomenon}

A total of 22 procedures were performed on 13 patients ( 12 female, 1 male, 9 patients with bilateral procedures). The mean age in this group was 50 years (range 46-61). All patients were classified as having secondary Raynaud's phenomenon.

The proven underlying disease was progressive systemic sclerosis.

\section{Asphyxia}

A total of 21 procedures was performed on 20 patients ( 8 female, 12 male, one patient with a bilateral procedure). The mean age in this group was 48 years (range 27-65). All patients were classified as having asphyxia. In all patients obstructive lesions of one or more digital arteries were confirmed by angiography. The origin of the asphyxia was a hypothenar hammer syndrome in 4 patients. In seven patients arteriosclerosis and in six patients (one bilaterally operated) tromboangiitis was the underlying disease. Micro emboli were proven angiographically in 3 patients although their origin could not be detected. Twelve patients complainted of severe ischaemic pain in one or more fingers. In eight patients trophic skin lesions were present as well as ischaemic pain.

\section{Post-traumatic dystrophy}

Twelve sympathectomies were performed in 12 patients ( 6 female, 6 male) with posttraumatic dystrophy. The mean age in this group was 41 years (range 23-54).

Four patients had sustained factures of the upper extremity, four had trauma without fractures, two developed post- traumatic dystrophy after surgery for infection in the arterior closed space of the terminal phalanx of a finger, and two developed dystrophy after first rib or cervical rib resection.

Four were classified in stage II and eight in stage III of dystrophy (Chapter III). In all cases the diagnosis was made by clinical history, physical and $\mathrm{X}$-ray examination. 


\section{Causalgia}

One male patient (age 57 years) was treated for burning pain in his left arm although this has been amputated after a gun-shot injury.

In patients with bilateral sympathectomies the operations were performed in two consecutive stages. The removed specimens were examined histologically. The presence of sympathetic ganglia was confirmed in all cases. Special staining for peripheral nerves, an acetylcholinesterase method, performed on some resection specimens has already been presented (Chapter VI).

The criteria for the classification of the effect of sympathectomy corresponded with the criteria used by other authors $(25,27,46,52,106)$. The criteria used are described in table VII.1.

Table VII.1:

\section{Classification of results of sympathectomy}

Good results. Total or almost total disappearance of vasospastic or asphyctic attacks and pain, return of oedema, normal hand temperature, dry skin, healing of eventual trophic lesions.

Fair results. Decrease in vasospastic or asphyctic attacks and pain, improvement in degree of oedema and skin appearance, stabilisation of clinical symptoms at a less serious stage.

Poor results. Persistence or reappearance of vasospastic or asphyctic attacks, pain and other clinical symptoms, at the same stage of severity.

The long-term results are presented in relation to the recurrence time postoperatively. Four follow-up moments are introduced:

- at 3 months postoperatively. Several authors mentioned early relapses in the first postoperative months $(10,128)$. The direct postoperative failures are included in this period.

- at 2 years. Most relapses are seen in the first two years after operation $(10,39,46,70$, .

- at 5 years. In the period from 2 to 5 years postoperatively recurrences of sympathetic impulses and related complaints can still take place $(10,39,149)$.

- at more than 5 years. This period was introduced to judge the number of relapses many years after operation separately.

A point of discussion is the significance of the method of classification used for evaluation of the results. Objective methods to classify the results are not available. The most difficult group of patients are those who scored a fair result (return of complaints fewer in comparision to the preoperative state. In particular the often gradual increase of complaints spread over years make interpretation difficult. Therefore it is questionable whether these patients should be included in the overall successful results. An other point of discussion is that the efficiency of a sympathectomy is not only determined by the immediate success but also depends upon the long-term results. In order to evaluate the efficiency of a treatment method, a system is necessary which records success and failure data for prolonged periods after therapy. Data which provide only the 
total failure rate at a final evaluation time within a patient population consisting of individuals treated for long period, cannor be used to evaluate a method or compare different methods of treatment. The number of failures and the number of individuals treated for specific discrete time periods need to be specified. The adoption of the life table-method in reporting and comparing treatment effects in patients with ischaemic hand phenomena using an uniform patient classification, would provide information of great value. The life-table method identifies those extremities at risk for each postoperative time interval after operation. The term 'at risk' defines those extremities followed at least for the designated of years, but does not include extremities which postoperative course (follow-up) is shorter than the interval (137, 138).

The number of extremities at risk at any time interval represents the total population minus the cummulative relapses and those extremities which postoperative course is less than the time indicated.

In addition to the generally applied method for reporting results as discussed in the literature, the life-table method is introduced in this study. The successful operations (good results) are presented separately.

The direct operative failures are scored in this study as the results within one week postoperatively.

Most patients were seen at the outpatient clinics several times afterwards. All surviving patients, except those who could not be traced, were seen for re-examination by the author. Mean follow-up was 8.5 years (range 2-14.5).

In 9 patients it was not possible to perform a re-examination. Seven patients died in the follow-up period. They died more than two years postoperatively in all cases ( 4 with progressive systemic sclerosis, 1 with a primary Raynaud's phenomenon and 2 patients with asphyxia).

Two patients were lost in the follow-up period. One after an unilateral procedure for primary Raynaud's phenomenon and one after a bilateral operation for asphyxia.

\section{VII.2 Results}

\section{Primary Raynaud's phenomenon}

The results of sympathectomies in patients with primary Raynaud's phenomenon have been presented in figure VII.1 and table VII. 2 . The results have been calculated by the life table-method for those classified as 'good'. The immediate results were good in $96 \%$. Three years postoperatively most patients $(77 \%)$ had a relapse of symptoms. In the following years the results decreased further and only $15 \%$ of the cases could be considered to have good results. However the good results did not decrease any further in the period more than 5 years postoperatively.

In figure VII. 2 The results are presented according to the method usually used in the literature. Two patient were lost for follow-up. Most relapses occurred within 2 years postoperatively. The relapses seen after more than 2 years postoperatively had a mild character in comparison to the pre-operative state. If fair results are included, $62 \%$ of the cases has been improved by operations at the time of re-examination. 


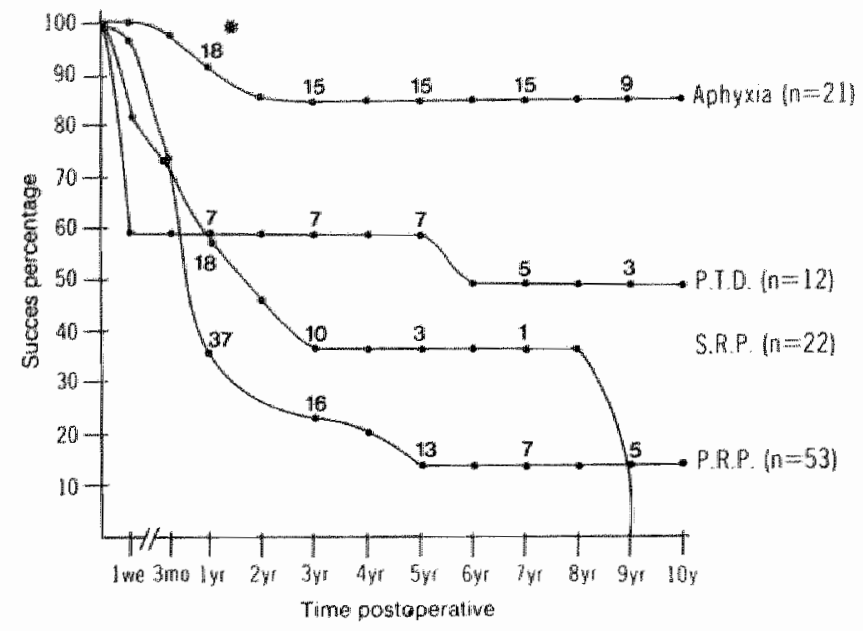

Figure VII.]

Succes percentage in cases, with primary Raynaud's phenomenon (P.R.P. h, secondary Raynand"s phenomenon (S.R.P.), post-traumatic dystrophy (IP,T.D.) and asphyxia calculated by the life-table method (* number of conses at riski).

\section{Primary Raynaud $(\mathrm{n}=51)$}

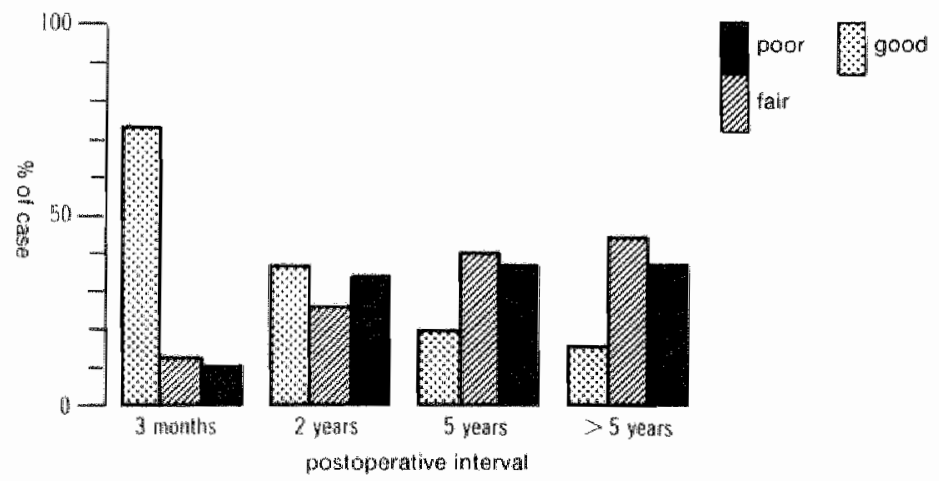

Figure VII.2

Resuits in cases with primary Raynand's phenomenon in relation to the recurrence-time 2 cases were lost for follow-up). 
Table VII.2:

Good results determined by the life-table method for cases with primary Raynaud's phenomenon

\begin{tabular}{llllccc}
\hline & $\begin{array}{l}\text { No. } \\
\text { extremities } \\
\text { at risk }\end{array}$ & $\begin{array}{l}\text { Recurrence } \\
\text { during } \\
\text { interval }\end{array}$ & $\begin{array}{l}\text { Lost } \\
\text { for } \\
\text { follow-up }\end{array}$ & $\begin{array}{l}\text { Interwal } \\
\text { failure } \\
\text { rate } \%\end{array}$ & $\begin{array}{l}\text { Interval } \\
\text { succes } \\
\text { rate } \%\end{array}$ & $\begin{array}{l}\text { Accumulative } \\
\text { succes } \\
\text { rate }\end{array}$ \\
\hline $1 \mathrm{wk}$ & 53 & 2 & - & 3.8 & 96.2 & 96.2 \\
$3 \mathrm{mo}$ & 51 & 12 & 2 & 24.0 & 76.0 & 73.1 \\
$1 \mathrm{yr}$ & 37 & 15 & - & 40.5 & 49.5 & 36.2 \\
$2 \mathrm{yr}$ & 22 & 6 & - & 27.3 & 72.7 & 26.3 \\
$3 \mathrm{yr}$ & 16 & 2 & - & 12.5 & 87.5 & 23.0 \\
$4 \mathrm{yr}$ & 14 & 1 & - & 7.1 & 92.9 & 21.4 \\
$5 \mathrm{yr}$ & 13 & 4 & - & 30.8 & 69.2 & 14.8 \\
$6 \mathrm{yr}$ & 9 & - & 2 & 0 & 100 & 14.8 \\
$7 \mathrm{yr}$ & 7 & - & 1 & 0 & 100 & 14.8 \\
$8 \mathrm{yr}$ & 6 & - & 1 & 0 & 100 & 14.8 \\
$9 \mathrm{yr}$ & 5 & - & - & 0 & 100 & 14.8 \\
$10 \mathrm{yr}$ & 5 & - & - & 0 & 100 & 14.8 \\
\hline
\end{tabular}

\section{Secondary Raynaud's phenomenon}

The results of sympathectomies in patients with secondary Ranaud's phenomenon are presented in figure VII. 1 .

The immediate results were good in $81 \%$ of the cases. Although most relapses $(64 \%)$ were found in the first three years. In the following years 7 cases were lost to follow-up because of death. In the years more than 5 years postoperatively, only 3 cases were at risk and because of shortness of follow-up and relapse in one case, the good results decreased to zero after 9 years follow-up.

In figure VII. 3 the results are presented according to the method used in the literature. Four patients ( 7 procedures) were lost to follow-up. Most relapses occurred within two years postoperatively. If fair results are included, $67 \%$ of the cases were improved by operation. No cured patients were seen at the re-examination time.

\section{Asphyxia}

The results of sympathectomies in patients with asphyxia are presented in figure VII.I determined by the life-table method.

The immediate results were good in $100 \%$. Within the first 3 years relapses were seen in three cases $(17 \%)$. In the following years the patients with good results remained in a stable condition ( $83 \%)$.

In figure VII. 4 the results are presented according to the method used in the literature. Three cases were lost to follow-up. After 2 years of follow-up, no increase in recurrences of symptoms was seen. If fair results are included, $90 \%$ of the cases were improved by operation. 


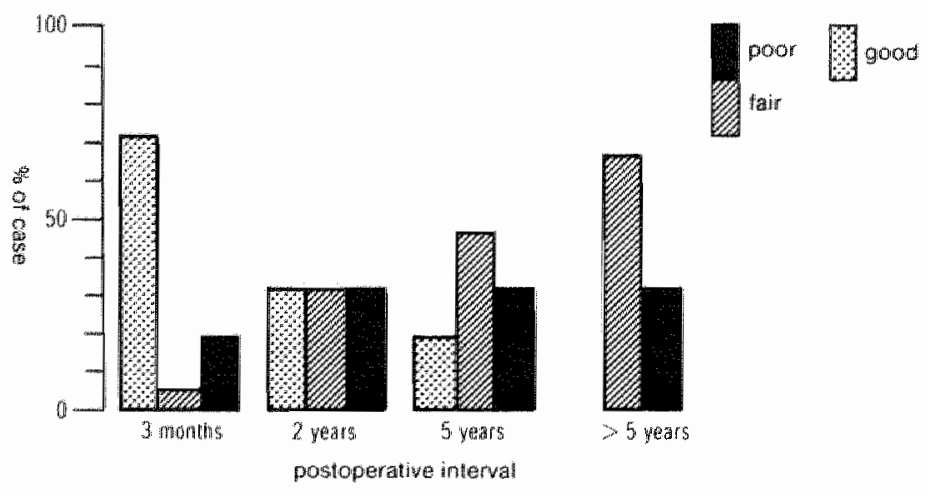

Figure VII.3

Resalls in cases with secondary Raynaud's phenomenon in relation to the recurrence-time ( 7 cases were lost for follow-upi),

Asphyxia $(n=18)$
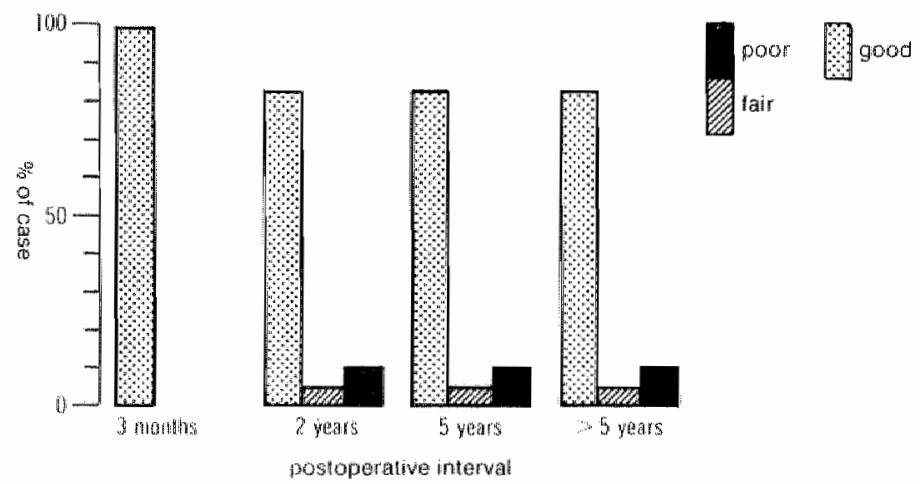

Figure VII. 4

Results in cases with asphyxia in relation to the recurrence-time ( 3 cases were lost for follow-up).

\section{Post-traumatic dystrophy}

The results of sympathectomies in patients with post-traumatic dystrophy are presented in figure VII. I calculated by the life table method. The immediate results were good in $58 \%$. These patients were relieved of their burning pain and most of them $(83 \%)$ were classified in stage III of disease (Chapter III).

After follow-up for more than 6 years postoperatively, the good results remained stable in $49 \%$. It has to be noted that only 5 cases were at risk 7 years postoperatively.

In figure VII.5, the results are presented according to the method used in the literature. Most relapses were seen within 3 months postoperatively most relapses were seen because of 4 patients who had no benefit at all from the operation. In only one case was recurrence 
Post-traumatic dystrophy $(n=12)$

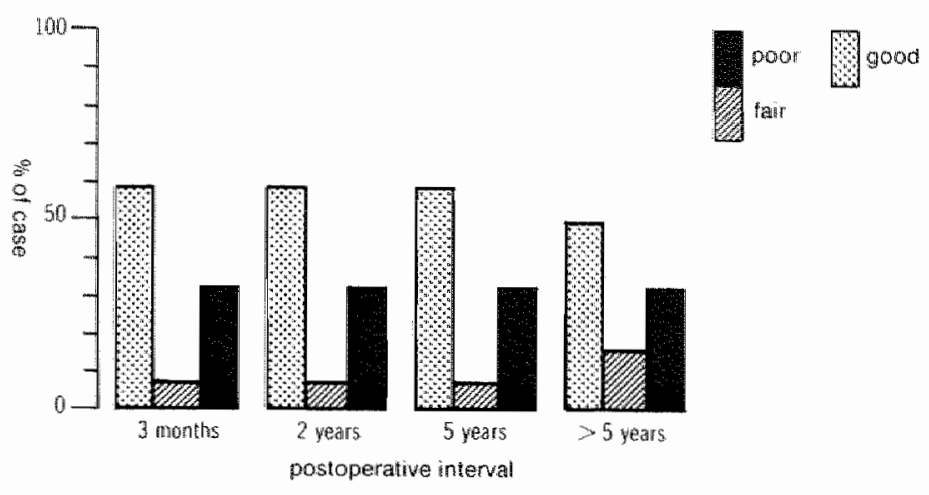

Figure VII.5

Results in cases with Post-traumatic Dystrophy in relation to the recurrence-time.

of symptoms seen in the follow-up period. If fair results were included, $67 \%$ of the cases are improved by operation at the re-examination time.

Causalgia

The single patient treated for burning pain was not relieved of his pain after operation.

\section{3 Complications}

There was no operative mortality.

A variety of complications were seen after thoracic sympathectomy. They are presented in table VII.3.

Table VII.3:

Complications after T.D.S. 'en bloc'

Horner's syndrome : $9(8 \%)$

Pneumothorax

: $4(4 \%)$

Haemothorax

: $2(2 \%)$

Wound infection

: $5(4 \%)$

Wound and back pain

$: 44(40 \%)$

Neuralgia

$: 28(25 \%)$

Gustatory response

: $4(4 \%)$

\section{Horner's syndrome}

The first sympathetic ganglion is in many instances, in part or totally fused with the stellate (inferior cervical) ganglion. Thus, for an adequate resection of sympathetic fibres to the upper extremity the lowest part of the stellate ganglion must be resected in these cases. At this point an extremely careful dissection is necessary to avoid injuring or destroying the ciliary pathway to the pupil, thereby averting Horner's syndrome. Horner's syndrome has been known as a complication of sympathetic surgery for the 
upper extremities even since the first operations. Through abandoning the resection of the stellate ganglion and resection of the second and third sympathetic ganglia only, this complication was seldom seen.

In the present study of 109 sympathectomies a permanent Horner's syndrome was seen in 9 cases ( $8 \%$ ). Van de Wal (150) quoted $3 \%$, Linder (93) 3\% and Jochismen (69) $5 \%$ as the occurrence rate of Horner's syndrome after sympathectomy.

Welch (153) described several methods for operative management of the stellate ganglion, resulting in prevalence rates for Horne's syndrome varying from $30 \%$ to $70 \%$. In contrast to Palumbo (107), he resected the lower half instead of the lower third which might explain the high prevalence in his series. Palumbo saw Horner's syndrome in $3 \%$ after his type of resection.

\section{Pneumothorax and haemothorax}

In 4 cases ( $4 \%$ ) a pneumothorax was seen postoperatively. A chest $\mathrm{X}$-ray was taken routinenly postoperatively. Only in one patient was drainage of the pleural cavity necessary.

In 2 cases $(2 \%)$ a small haemothorax was seen, but drainage was not neccesary in either patient.

Linder (93) saw pleural effusion in $18 \%$ of his patients after his transaxillary approach. In a quarter of these cases a drainage puncture of the pleural cavity was performed. A 4\% haemothorax rate was described by Van de Wal (150). Two of his patients required rethoracotomy. Different transpleural approaches were used. In his study Jochismen (69) found $8 \%$ pulmonary complications after his transaxillary approach, but the nature and extent of these complications were not mentioned in detail. Welch (153) reported a pneumothorax in $8 \%$ after the supraclvicular approach.

\section{Wound infection}

In this study wound infections were seen in $4 \%$ of the cases. Except in these patients no other wound healing disturbances were seen. A much higher percentage of wound healing disorders was reported by Linder with his transaxillary approach $(17 \%)$. Van de Wal found infections and wound healing disturbances in $14 \%$. The type of approach in relation to the wound infection was not mentioned.

\section{Postoperative pain}

Another complication which was seen rather frequently was the postoperative pain, particularly after a thoracodorsal approach. In the present study pain, was seen in forty percent of all cases (44/109) and was often long lasting.

In $25 \%$ of the cases (28/109) patients complained of neuralgic pains radiating to the front of the chest as result of the partially resected intercostal nerves. In $25 \%(7 / 28)$ of these patients resection of the intercostal nerve was necessary to relieve the patients of this persisting pain.

In one patient with a bilateral procedure in whom the first rib on both sides had previously been resected it was necessary to stabelize the upper thoracic spine because of the development of a thoracic scoliosis and related severe complaints.

\section{Gustatory response}

Another recognised complication is the so-called gustatory response. In some patients, excessive sweating occurs in several places, especially the contralateral half of the head and the opposite arm after smelling or eating certain kinds of food. In this study four 
patients (4\%) were not able to eat particular types of food because of this complication. These symptoms occurred after several years, mostly accompanied by a relapse of complaints in the hands. An explanation for this phenomenon might be the regeneration of sympathetic fibres developing connections with sympathetic fibres with other functions.

\section{VII.4 Discussion}

Since the beginning of this century sympathectomy of the upper extremities has been a challenge for many surgeons, not only because of the primary techniques used but especially the requirement to treat the complications and failures of these operations.

Techniques and indications have changed many times in order to select patients who could benefit from thoracic sympathectomy.

One of the main indications is Raynaud's phenomenon. A differentiation needs to be made between primary (without) and secondary Raynaud's phenomenon (with underlying disease). In patients with a primary Raynaud's phenomenon it is a clearly accepted procedure, whereas in patients with a secondary Raynaud's phenomenon there is a difference of opinion.

Operations on the autonomic nervous system are clearly accepted in the treatment for palmar and axillary hyperhydrosis because of the favourable results recorded.

There is an indication for a sympathectomy in patients with obliterative arterial disease when localisation and the extent of the lesion make vascular surgery impossible.

The place for treatment of post-traumatic dystrophy is mentioned by many authors with varying degrees of succes. The aim of this thesis was to evaluate the introduced modified operation technique and investigate whether it influenced the overall results positively, compared with results in the literature.

\section{Primary Raymaud's phenomenon}

In this study, patients with a primary Raynaud's phenomenon, if partial successes are included, showed an improvement of $62 \%$ at re-examination. Relapses in patients more than 2 years postoperatively were of a a mild nature. An explanation may be that regenerated sympathetic fibres had a diminished vasomotor activity. Comparing these results with the literature almost the same percentages of improvement was seen: Van de Wal (150) 51\%, Baddely (10) 54\%, Johnston (70) $58 \%$, Gifford (46) 63\% and Felder (39) $64 \%$. In all these results, patients were included who had relapse of their symptoms but claimed improvement in comparison to the preoperative state. However, for recommendation of a sympathectomy it is questionable if these results should be included. Because the increase of complaints after surgery is often gradual, interpretation and classification is difficult several years after symphatectomy. The good results are therefore presented separately in this study. The results presented by the life-table method show a low percentage of procedures yielding a permanent good result on the long term (15\%). These procedures were re-evaluated. In spite of careful analysis of the preoperative data such as history, laboratory data or angiography, no observations could be found to distinguish these patients from the other patients. A suitable explanation for this phenomenon might be the great variation in anatomy already discussed in detail in chapter. VII. 


\section{Secondary Raynaud's phenomenon}

In the patients with secondary Raynaud's phenomenon an improvement was seen in $67 \%$, although none of them had a good result at the re-examination time. The life-table method showed a success rate of $36 \%$ after 5 years follow-up but only 3 cases were left for evaluation. After 9 years, no patients without complaints were left because of the shortness of follow-up and because of one patient who had recurrence of her symptoms. Mattasi (98) described the same questionable final results in patients with scleroderma or other collagen diseases. Gifford (46) and Manart (97) also mentioned poor results. On the contrary $(11,153)$ some authors have published satisfactory results. The differences in the results reported are due to the variability in interpretation of the findings. Most patients show the same pattern after operation. They have benefit direct postoperatively, but relapse of complaints is seen in a high percentage in the follow-up period. Except for return of symparhetic activity the progress of the underlying disease in patients with progressive systemic sclerosis is responsable for the disappointing results on the longterm.

\section{Post-traumatic dystrophy}

Sympathetic blocks, immobilisation, active physiotherapy and hydroxyl radical scavengers have been advocated as treatment $(48,53,133,142)$. Welch (153) concluded that his group of patients had a high degree of emotional instability and should be managed by nonsurgical methods if possible, although some patients in his report had satisfactory results after sympathectomy. Many authors $(19,76,97,109,133,147)$ claim good results but in almost all such studies the exact describtions of patients are not presented nor is the state of disease of the treated patients mentioned.

The group of patients with post-traumatic dystrophy showed improvement in $67 \%$ after 5 years (Fig. VII.5). The results calculated by the life-table method gave $49 \%$ good results on the long-term (Fig. VII.1). These patients were relieved of their burning pain, 5 were classified using the classification of Drucker (34), in stage III and one in stage II of disease. Six patients had no benefit from sympathectomy: four were in stage II and two in stage III of the disease. Steinbrocker(135) in 1948 recommended sympathetic surgery in stage II of disease. In stage III he saw relief of pain but in most patients rehabilitation of muscular and digital function was often not possible. The number of patients in stage II of posttraumatic dystrophy in the present study was too small to confirm this statement. In five patients in stage III of the disease the same pattern was seen: an excellent result with relief of pain but only a limited improvement in mobility of the affected hand and fingers.

\section{Asphyxia}

The analysis in the group of patients with asphyxia showed an improvement at the reexamination time in $90 \%$ of the patients. One patient with ischaemic skin lesions initially responded favourably but within half a year the amputation of two fingers was necessary. General arteriosclerosis was the underlying disease.

The life-table method results showed that after 2 years the percentage of good results remained constant at the level of $83 \%$. (Fig. VII. 1).

A review of literature shows that satisfactory results of thoracic sympathectomy were usually obtained in patients with obliterative lesions. Welling (154) and Mc Namara (99) emphasised the potential beneficial effect of a sympathectomy in patients with severe ischaemic pain of the digits or early tissue necrosis, after exclusion of the possibility of direct vascular reconstruction. No exact details of the patients were given. An 
improvement of $70 \%$ was claimed by Van de Wal (150), $90 \%$ by Linder $(93)$ and $94 \%$ by Mattasi (98). An improved collateral circulation is probably the explanation for the promising results in these patients. The clinical diagnosis seemed to be important in patients with obstructive lesions demonstrated by angiography of the hand. In patients with collagen diseases the results are usually poor although obstructive lesions are present.

\section{VII.5 Conclusions}

1. In spite of the use of a new extended technique for sympathectic denervation of the upper extremity, no decrease in the high percentage of recurrences was achieved, compared with the results in the literature.

2. In patients with primary Raynaud's phenomenon the results, specifically the successrates were disappointing. Since relapses of symptoms are frequently seen and in most patients the natural history is mild $(45,63)$ it is questionable whether patients with primary Raynaud's phenomenon should be treated with a sympathectomy at all. In patients with a secondary Raynaud's phenomenon a thoracic sympathectomy should be reserved for special cases with severe ischaemic pain or when fingers are at risk.

3. A thoracic sympathectomy can relieve patients with post-traumatic dystrophy of their burning pain.

4. In patients with asphyxia after exclusion of the possibility of direct vascular reconstruction, successful results can be expected from sympathectomy.

5. The high percentage of patients with longlasting postoperative pain is a serious drawback to the posterior approach. 



\section{Chapter VIII}

\section{Re-sympathectomy}

\section{VIII.1 Introduction}

The high percentage of recurrences after thoracic sympathectomy is an unsolved problem (Chapter II). Operative procedures have been modified several times. Most procedures have good results direct postoperatively, but recurrences are frequendy seen. Many explanations for these failures have been given. The anatomical variation in the sympathetic chain is one of the most important explanations $(3,39,55)$. The intrathoracic nerve of Kuntz (78) wia which sympathetic nerve fibres reach the brachial plexus without passing through the sympathetic trunk, may be an explanation for such failures. Kirgis (73) in 1942 described a similar nerve bundle connecting the second and third intercostal nerve.

Regeneration of preganglionic fibres is another explanation for the return of vasospasm after sympathectomy for Raynaud's disease $(10,39,56,128,131,145)$. The fact that autonomic nerve fibres regenerate in animals lends credence to this point of view $(86,127)$. In patients where the sympathetic tone in the bloodvessels of the hand returns, or a residual sympathetic tone appears to persist, a re-sympathectomy seems to be a logical consideration. This is especially true in patients in whom previous operation has removed only sympathetic ganglia without resecting the second and third intercostal nerves and surrounding tissue.

Lemmens (89) in 1982 described the possibility of a re-sympathectomy in this kind of patients.

By resecting the second and third intercostal nerve and surrounding tissue 'en bloc' he was able to achieve a re-sympathectomy effect.

\section{VIII.2 Patients and methods}

27 Patients were presented from other hospitals after an upper thoracic sympathectomy. In all patients only the sympathetic ganglia had been removed by an axillary approach; $67 \%$ of the patients had transient success for 6 months up to 2 years. The other $33 \%$ had no respons at all after the previous operation.

All patients underwent a re-sympathectomy by the posterior extra pleural approach. The technique is described in detail in chapter V.2. The second and third intercostal nerves with their spinal ganglion and surrounding tissue were removed. The high thoracic sympathetic ganglia had been resected in all patients in the prior operation and were not found at re-operation.

In the 27 patients 35 sides were operated on. Related to the clinical diagnosis, they could be divided into four groups (Fig. III.1).

\section{Primary Raynaud's phenomenon}

Fifteen patients ( 14 female, 1 male) were classified as having primary Raynaud's phenomenon and 22 sides were operated on.

The mean age in this group was 38 years (range $22-51$ ). 


\section{Secondary Raynaud's phenomenon}

Three re-operations were performed in 3 patients (all female) who respectively ages were 49,50 and 61 years. Progressive systemic sclerosis was the underlying disease, verified by histological skin biopsies or oesophagus $\mathrm{X}$-ray examinations.

\section{Asphyxia}

Seven patients ( 2 female, 5 male) were classified as having asphyxia. The mean age in this group was 50 years (range 32-60) and 8 sides were operated on. One male patient had tromboangiitis as the underlying disease, and was bilaterally operated. Two patients had atherosclerosis and one patient had a hypothenar hammer syndrome. Microemboli were found in 3 patients but their origin could not be found in two instances, although in one case a thoracic outlet syndrome was considered as the source. In this patient the first rib was also resected.

\section{Post-traumatic dystrophy}

Two re-operations were performed in two female patients, aged 35 and 40 years respectively. One was classified as stage II, the other as having stage III of disease (32).

The classification criteria for the effect of sympathectomy have been decribed earlier (Table VII.1). One patient was lost to follow-up. The mean follow-up period was 6.9 year (range 3.0-12.0).

\section{3 Results}

Direct subjective improvement after re-sympathectomy was seen in 21 patients ( 27 operations). In 6 patients ( 8 operations) no relief of complaints was achieved after reoperation. Five of these patients ( 7 operations) were diagnosed as having primary Raynaud's phenomenon and one as suffering from secondary Raynaud's phenomenon with progressive systemic sclerosis as the underlying disease.

The analysis of the results is presented for each different groups separately. Objective data of successful operations will be discussed in Chapter X (Table X.2).

\section{Primary Raynaud's phenomenon}

The results of the patients with primary Raynaud's phenomenon are presented in figure VIII. 1. The results have been determined by the life-table method for those classified as good. The immediate results were good in $68 \%$ of the procedures. Three years after operation in $75 \%$ of the procedures patients had a relapse of symptoms. After follow-up more than 5 years postoperatively the good results remained stable (21\%).

In Figure VIII. 2 the results are presented according to the method used in the literature. Within 3 months a high percentage poor results $(40 \%)$ was found because of the 5 patients ( 7 procedures) who had no improvement at all after re-sympathectomy. If fair results are included, $32 \%$ of the cases were improved by operation.

The overall good results of the re-operation compared with the primary' operation are presented by the life-table method in figure VIII.1. The only differences found were the immediate results respectively $96 \%$ for the 'primary' and in $68 \%$ good results for the reoperated group. In the following period of 3 years the relapses in both groups showed the same tendency. The good results decreased to approximately the same level ('primary' operation $23 \%$, re-operation $25 \%$ ). After 5 years no further recurrences were seen in either group.

It should be mentioned that in the re-operated group only 3 cases were left at risk after 7 years follow-up. 


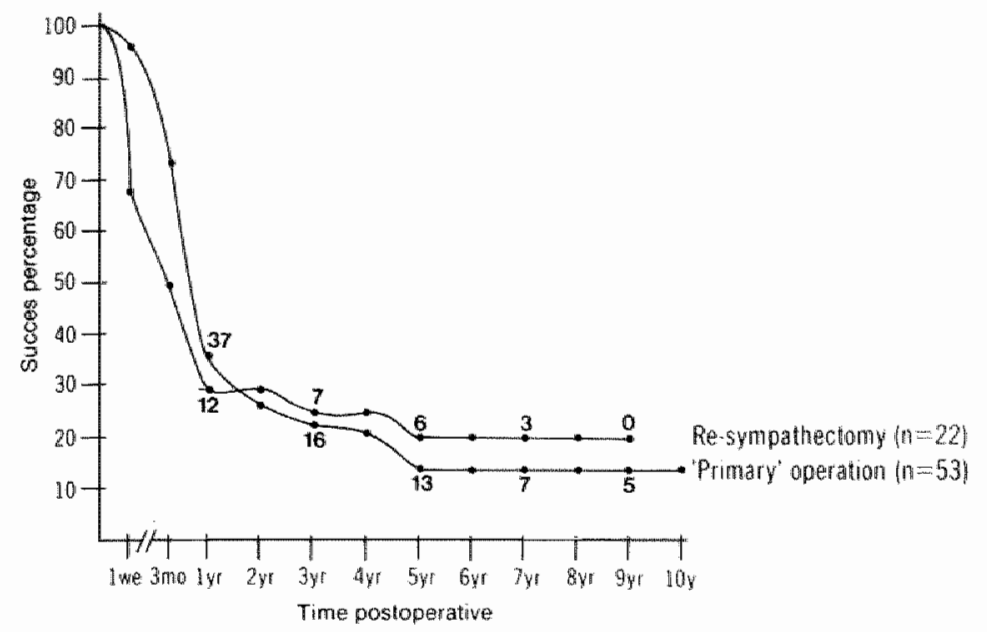

Figure virl. 1 .

Suces percentage in cases with the clinical diagnosis Primary Raynaud s phenomenon after a "primary" on Re-sympanthecumy calculated by the lifi-table method.

Primary Raynaud after re-sympathectomy $(n=22)$

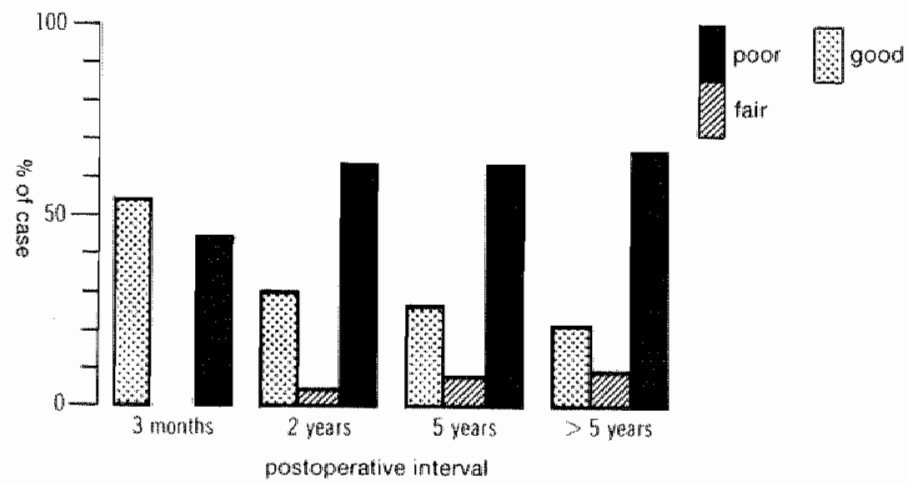

Figure VIII.2

Results in wess with Primary Raynaud"s phenomenon after Re-sympathodomy in relation to the recurrence time.

\section{Secondary Raynaud's phenomenon}

In the 3 patients with secondary Raynaud's phenomenon no improvement was seen in one patient, and one other patient only had relief of complaints for several months. The third patient died of cardiac arrest before a final re-evaluation could be performed. She had already been treated several times with plasmapheresis because of return of complaints.

\section{Asphyxia}

Good results were achieved in all eight procedures in the immediate postoperative period. In three cases however, relapses of symptoms occurred to the same stage of severity as preoperatively. The other five cases were free of symptoms at time of re-examination. The follow-up period was more than 6 years in these cases. 


\section{Post-traumatic dystrophy}

Two patients were treated for post-raumatic dystrophy. The patient who was classified in stage III was relieved of all her pain. The other patient classified in stage II still had symptomes although she claimed to be improved compared with the pre-operative state.

\section{VIII.4 Complications}

Postoperatively, except for 2 patients $(6 \%)$ who developed Horner's syndrome and 2 patients with pneumothorax, no serious complications were seen. Complaints of longlasting pain around the scar and in the back were noted in sixty percent of the patients.

\section{VIII.5 Discussion}

As already briefly discussed there are many possible explanations for the frequent relapses after thoracic sympathectomy. The anatomical study described in chapter VI forms the basis for the following explanations.

Alternative pathways in the upper paravertebral region can explain the early relapses. It is possible that these pathways remain intact despide the operation and subsequently replace the function of the resected sympathetic fibres.

The relapses on the longterm can be explained by the regeneration of divided fibres.

The analysis of patients who underwent thoracic re-sympathectomy lends support to both these explanations. In $77 \%$ of the cases a succesful re-sympathectomy with the 'en-bloc' operation technique was seen as a direct result and these patients clearly showed subjective improvements of their symptoms, most probably due to resection of sympathetic fibres. Patients with early relapses or no relief at all after the previous sympathectomy, as well as patients with relapses on the long-term are included. Confirmation of these subjective results were seen through objectivation by continuous wave Doppler registrations in 14 patients (Chapter X Table X.2).

In the literature only a few authors have reported their experience after re-operation. In 1951 Jepson (67) described a patient who was re-explored by the posterior route two years

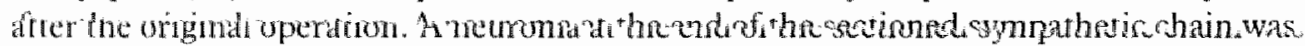
found but there were no anatomical connections in between. No evidence of regeneration as a cause of relapse was found. He was not able to cure the patient. Cohen (28) in 1951 confirmed the absence of regeneration in his re-exploration.

The experience of Peacock (110) in re-operations was that removal of the scar tissue on the side of the previous operation, together with excision of the stellate ganglion, was followed by vasodilatation of the vessels of the upper extremity. However after this re-operation his patients had no long-term benefit. Haxton $(56,57)$ also believed that re-sympathectomy of the upper extremity was possible. He re-operared on one patient by clearing away the fibrous tissue over the heads of the second and third ribs on each side. No Horner's syndrome resulted, but the hands became hot and dry and the sympathetic activity was absent, contrary to the situation pre-operatively. The preoperative presence of sympathetic fibres was confirmed by ulnar nerve blockade. His only likely explanation for the relapse was regrowth of divided fibres to restore functional continuity.

Mattassi (98) made a special plea to reserve the axillary approach for re-operations. In one case he found a normal sympathetic chain without interruption, although in the first operation, histological confirmation of removal of the second and third ganglia was obtained. His explanation was complete regeneration of sympatheric chain. 
The results presented in this chapter show that a sympathectomy effect is possible after re-operation. The long-term results showed the same pattern in all groups of patients as compared with the results of the 'primary" operation presented in chapter VII. In parients with a primary or secondary Raynaud's phenomenon the results are disappointing. It was obvious was that in 3 patients ( 5 cases) with primary Raynaud's phenomenon no relief of complaints could be achieved. The same disappointing results were the outcome of the 'previous' operation in these 3 patients. A possible explanation might be the anatomical variations. The extensive technique used for re-operation, may still not be extensive enough to interrupt all the sympathetic fibres to the affected extremity.

The best results were obtained in the patients with asphyxia, although in one patient with tromboangiitis who did not stop smoking the progress of the disease was severe. After six months of relief, necrotic skin lesions occurred and amputation of three fingers was necessary.

An anatomical explanation for the almost identical longterm results after "primary" sympathectomy and re-sympathectomy is probably the same anatomical variations and the limitations of the extent of operation used. The extent of the sympathetic tissue and intercostal nerves which are resected are the same after botl procedures.

\section{VIII.6 Conclusions}

It is possible to obtain a re-sympathectomy effect with the technique described but it should be reserved for special cases where survival of digits is mandatory. A note of caution must be given concerning the postoperative longlasting back pain after the posterior approach. However in re-operation it is nevertheless the best approach for a clear anatomical view of the intercostal nerves and the surrounding tissue which have to be resected. 



\section{Chapter IX}

\section{Evaluation of the value of angiography in selecting patients for sympathectomy}

\section{IX.1 Introduction}

The possibility of using angiography for selecting patients with ischaemic hand phenomena for sympathectony is stated by sone authors. In particular the presence of obstructive lesions of the diginal arteries ought to predict poor results $(96,125)$. In this sudy the predictive value of angiography tor successful results was investigated.

\section{IX.2 Patients and methods}

Angiographic results of the upper extremty wete avaleble for investigation in 85 patients, who underwent a horacodorsal sympathectomy "en bloc" ( 36 bilateral). Primary and reoperations were included. A tolat of 121 anghographies were evaluated.

Angiography of the upper extremity and of hand and Ingers was performed by percutaneous transfemoral catheterisation (Seldinger technique). Radiographs were taken by a standardized method described in Chapter IV.

For evaluation of the angiographic signs the gradation described by Rösch(121) was used (Table IV:1).

The criteria used for the classifucation of the effecr of sympathectomy are described in Table VII:L.

For separate determination of the resuls classified as good, llfe- table method was used (Chapter VW).

All interpretations of angiographic disturbances and postoperative results were evaluated sevarately from chincal dagnosis. Mean follow-up was 8.1 years (range 2-14.5). In adfition to the sort of angiographic signs, the influence of the gradation of angiographic abnormalities on the success rate was investigated.

Finally, the results in patients with the clinical diagnosis of primary Raynaud's phenomenon were evaluated in relation to the pathological angiographic signs.

To test if there was a statistically significant difference between the successrate curves determined by the life-table method, the generalised Wilcoxon test was used.

\section{IX.3 Results}

The angiographies could be divided into two groups, i.e, one with and one without obstructive lesions. The group without obsuructive lesions could be divided into 'normal' angiograms and angiograms representing vasospasm (Table IV. 3 ).

Figure IX.1 shows the results determined by the life-table method for the classified good results. Within 3 years the good results decreased more than $50 \%$ in each separate group. Small but not significant differences were found: $46 \%$ good results in the obstructive group, $36 \%$ in the 'normal' group and $28 \%$ in the vasospastic group. In the long-term the results in the obstructive group were significantly better $(\mathrm{p}<0.05)$ than those in the 'normal' group. The patients in $9 \%$ of the cases with "normal' angiographic findings were without complaints, compared to $35 \%$ in the obstructive and $29 \%$ in the group with 


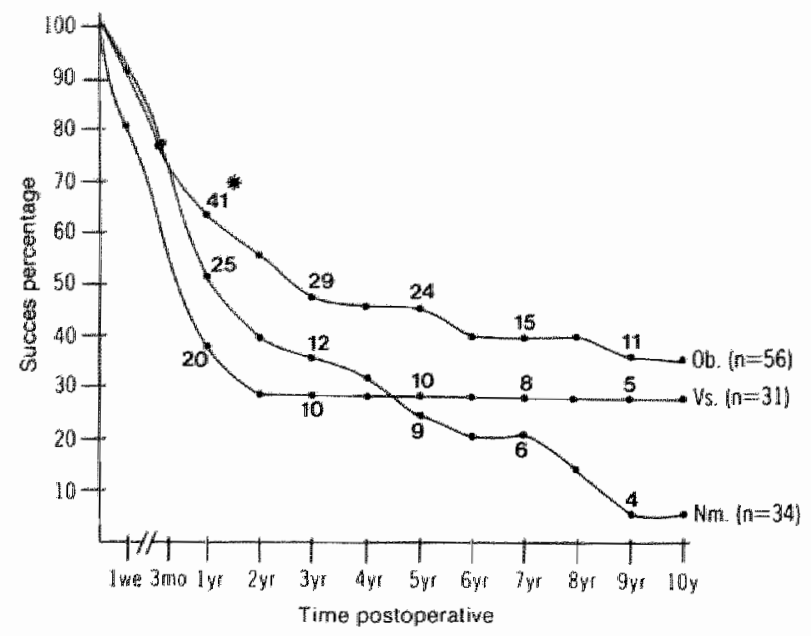

Figure IX.1

Succes percentage in cases with a 'normal' angiography (Nm), vasospastic (Vs) or obstructive angiographic signs (Obj calculated by the life-table method. (" number of cases at risk.)

\section{Angiography}

Normal $(n=33)$

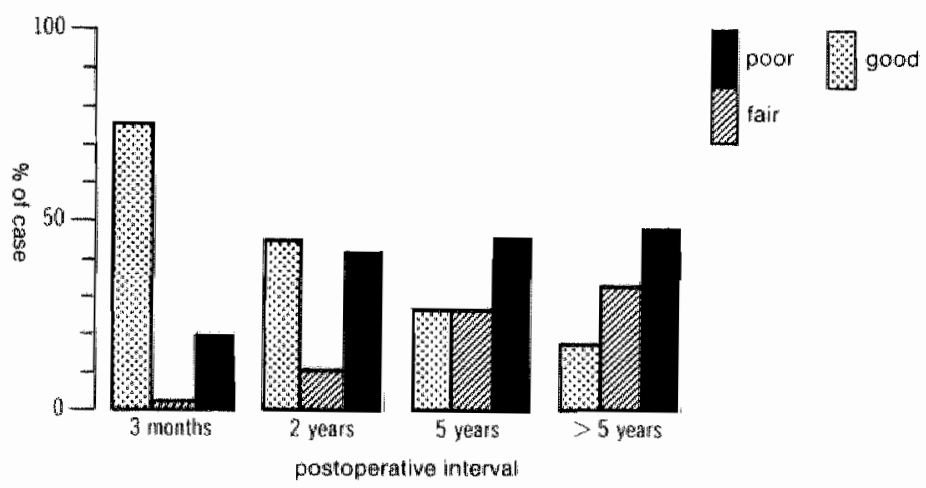

Figure IX.2

Result's in cases with no angiographic disturbances in relation to recurrence-time ( 1 case was lost for follow-up).

angiographic vasospasm. It has to be mentioned that the number of cases at risk on the long-term were small.

In figure IX,2, the results are presented according to the method used in the literature for the patients with 'normal' angiographies. One case was lost to follow-up. During the follow-up the good results decreased. After more than five years follow-up $51 \%$ of the procedures yielded an improvement when the fair results were included.

In figure IX. 3 the results of the parients with angiographic signs of vasospasm are presented. All recurrences of symptoms were seen within two years postoperatively. When fair results are included, $58 \%$ of the procedures in patients with angiographic 


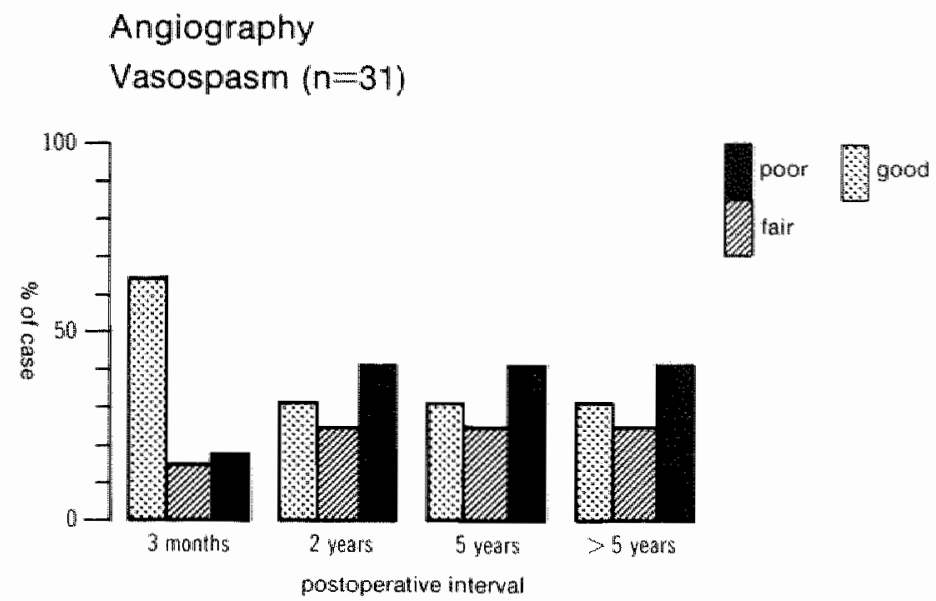

Figure IX.3

Results in cases with vasospasm in relation to recurrence-time ( 2 cases were lost for follow-up).

Angiography

Obstructive lesions $(n=54)$

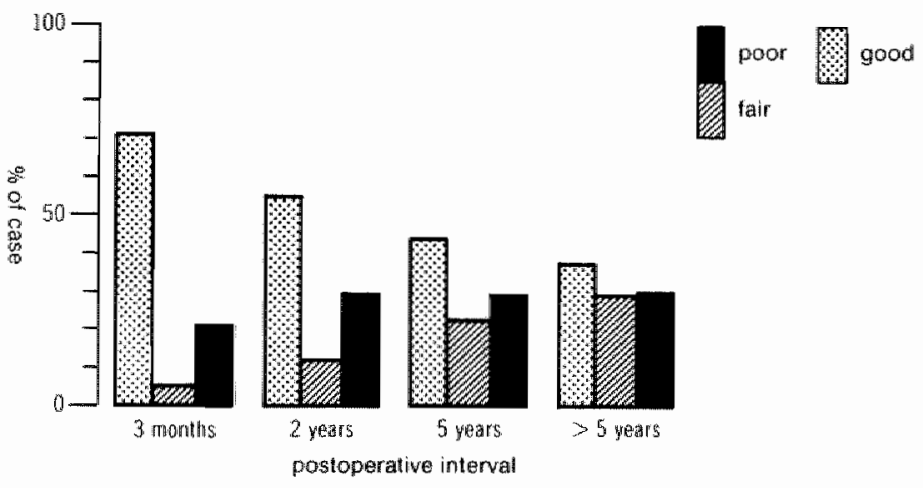

Figure IX.4

Results in cases witly angiographic obstructive lesions in relation to the recurrence-time 2 cases were lost for follow-up).

vasospasm gave improvement after a follow-up of more than 5 years.

In figure IX.4 the results of patients with angiographic obstructive lesions are presented. Two cases were lost to follow-up. During the follow-up period the good results decrease. After more than 5 years, when fair results are included improvement was seen in $69 \%$ of the procedures in patients with obstructive lesions.

The influence of the degree of angiographic obstruction on the results especially on the good results of sympathectomy was investigated. The resuits are presented by the lifetable method. Figure IX. 5 shows nearly equal results after 2 years follow-up in all 


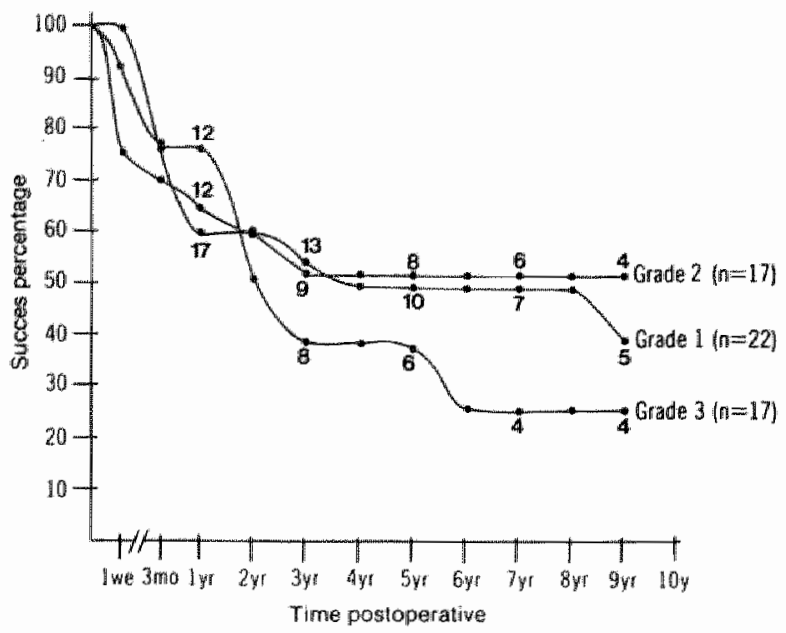

Figure IX.5

Succespercentage in cases with angiographic obstructive lesions in relation to the degree of obstruction calculated by the life-table method.

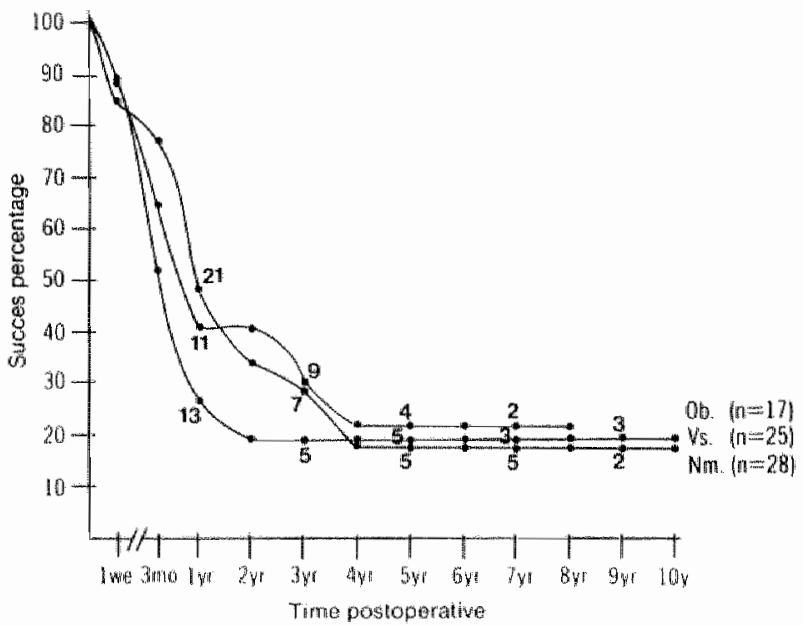

Figure IX.6

Suces percentage in cases with the clinical diagnosis primary Raynaud's phenomenon in relation to angiographic signs ('normal' angiography (Nm), vasospasn (Vs) and obstructive lesions (Ob)) calculated by the life-table method.

gradation groups. A decrease in good results of approximately $50 \%$ was found. After more than 3 years postoperative an almost stable success rate percentage was found in all gradations. In the long term the greatest reduction in good results, although not significant, was seen in Grade 3, to $26 \%$ after 7 years. Only 4 extremities at risk were left. 
The success rate of sympat thectomy in various angiographic gradation of vasospasm could not be calculated because most cases seen scored a Grade 1 of vasospasm $77 \%(24 / 31)$. The orher $23 \%(7 / 31)$ were divided over Grades 2, 3 and 4 . The data are too few to allow speculation on the influence of the grade of vasospasm on the postoperative results.

The results in patients with primary Raynaud's phenomenon in relation to angiographic signs are presented in figure IX.6.

The life-table method shows a marked decrease in good results in the first two years in each group. Almost identical results were seen three years postoperatively: $29 \%$ successrate in the obstructive group, $30 \%$ in 'normals", and $20 \%$ in the cases with angiographic vasospasm. In the period more than $*$ years postoperatively the suceess rates stabilised for all groups at about $20^{0 \%}$.

\section{IX.4 Discussion}

The value of angiography in selecting patients for sympathectomy was investigated. The results presented in figures: IX. 1-4 show the limited value of this invasive investigation for predicting favourable results. Only small differences were found more than 5 years postoperatively. No angiographic signs could be singled out for detecting patients who might show good results after sympathectomy.

The severity of angiographic obstructive lesions seemed not to correlate with the postoperative results (Fig. IX.5). Two years postoperatively the results in the various gradations were equal. In the long-term there was a small difference in favour of the patients with Grades 1 or 2 of obstruction, although they did not differ significantly from Grade 3 of obstruction.

Angiographic vasospasm Grade I was found in $77 \%$ of the cases but the overall results in cases with angiographic vasospasm were disappointing (Fig. IX.1). Because of the small number of cases in the groups with severe vasospasm, the effect of the gradation of vasospasm on the results could not be expressed. An explanation for the high percentage of patients with mild vasospasm must be that in this study no cold exposure angiograms were made, in contrast to the study of Rösch (116) who introduced the gradation used in this investigation. After cold provocation he saw severe grades of vasospasm.

Servelle (125) claimed surgical intervention in patients with Raynaud's phenomenon, before angiographic obstructions are visible because the results should be better in the vasospastic state. In his angiographic study he found in patients with primary Raynaud's phenomenon with prolonged symptoms of vasospasm, peripheral occlusions. His statement to operate on patients in the vasospastic state was not supported by a clinical study on patients with primary Raynaud's phenomenon.

Lynn (96) postulated that in patients with Raynaud's phenomenon a distinction could be made between the patients in whom obliterative arterial changes were present and those in whom no anatomical abnormality could be demonstrated by angiography. This distinction should be important in deciding upon treatment, because the patients without any anatomical angiographic abnormality should do well on treatment with vasodilator agents and sympathectomy, whereas little could be done to improve the circulation in patients with obliterative arterial changes. The improvement following sympathectomy would be slight, and early relapses would be the rule.

These statements could not be confirmed in the present study. The results shown in figure IX.6 emphasize this conclusion. After three years no difference was found in the results between the vasospastics (success rate 20\%), the 'normals' (success rate $30 \%$ ) and the 
obstructive group (success rate $29 \%$ ). In the following period the results stabilized for each group at about $20 \%$. An explanation for this disagreement could be the nomenclature used for clinical diagnosis. Lynn did not mention the exclusion of patients with progressive systemic sclerosis (P.S.S.) in contrary to this thesis. As described in this study, patients with secondary Raynaud's phenomenon with P.S.S. as underlying disease have poor results after sympathectomy. In these patients mostly obstructive lesions are found (Table IV.4).

Kent (68) concluded that the results of upper thoracic sympathectomy were unrelated to the degree of severity of the angiographic changes. Although only 18 patients were described, his final conclusion was that angiographic examination was only of limited value in patients with Raynaud's phenomenon.

The results of the present study are in accordance with those of Kent. The clinical diagnosis seems to be important in predicting successful results. Obstructive lesions are found in all clinical diagnoses (Table IV .4). In patients with asphyxia the results are good in contrast to those in patients with primary or secondary Raynaud's phenomenon (Chapter VII).

\section{IX.5 Conclusions}

The conclusion of this study is that selection of patients for sympathectomy is not possible on angiographic signs only.

There is no relation between results of sympathectomy and severity of the pathological angiographic signs. Also in patients with the clinical diagnosis of primary Raynaud's phenomenon the angiography makes no contribution to selecting patients who should benefit from sympathectomy. 


\section{Chapter X}

\section{Continuous wave Doppler: A quantitative Doppler study to evaluate postoperative results}

\section{X.1 Introduction}

The postoperative results of a thoracic sympathectomy are frequently evaluated by subjective criteria $(10,19,32,46,69,97,101,106,124,150)$. A review of several objective methods for evaluation of the results has been given in Chapter II.6. Evaluation of the long-term results of sympathectomy in patients with ischaemic hand phenomena is difficult. In particular the classification of patients who have recurrence of their symptoms but claim to be improved compared to the preoperative presented problems. Several authors $(39,57,127)$ described the return of sympathetic impulses to the upper extremity within two years after surgery. Most patients had recurrences of their complaints but no discrimination was made between fair and poor results.

The introduction of transcutaneous flow detection in the arterial system gave a new opportunity for evaluation of postoperative results in vascular surgery (141). The ultrasonic determination of flow velocity by the Doppler principle has been mentioned by several authors $(118,139,140)$. Several parameters of the Doppler signal are investigated for their value in the evaluation of vascular disease in the lower extremity. Fronek (42) reported that the peak forward velocity was a sensitive parameter for differentiating between healthy persons and patients with occlusive arterial disease. His quantitative ultrasonographic study demonstrated a decrease in peak forward velocity in patients with occlusive lesions compared to that in healthy persons. Rittenhous (120) found changes of peak forward velocity after changing the peripheral resistance. A decrease in peak forward velocity after increasing the peripheral vascular resistance was found and vice versa.

Successful interruption of sympathetic nerves results in arteriolar dilatation and a decrease in the vascular resistance. Changes in peak forward velocity of the arterial blood flow can therefore be expected after sympathectomy.

In this study the changes in peak forward frequency after sympathectomy are presented.

\section{2 Materials and methods}

Doppler signals were registrated before and one week after operation in 42 patients who underwent a thoracodorsal sympathectomy 'en bloc'.

From 34 of the 42 patients continuous wave Doppler signals were available at time of reexamination for this thesis.

Eight patients were lost for evaluation, 6 because of death and 2 who were not tracable.

Two groups of patients could be distinguished: 28 with 'primary' operations and 14 with a re-sympathectomy. Velocity wave-forms were recorded in the distal radial and ulnar arteries using a $8 \mathrm{MH} z$ bi-directional Doppler device with a zero crossing circuiting. Anatomical obstructions of the proximally situated arterial system were excluded by angiography. To obtain the most reproducible results, the recorded signal was scanned for maximum amplitude by moving the probe horizontally in the area of the expected 
signal. The angle of the probe position was varied again for maximum signal recovery. The peak forward velocity is expressed in Hertz (peak forward frequency: P.F.F.) (Fig. X.1).

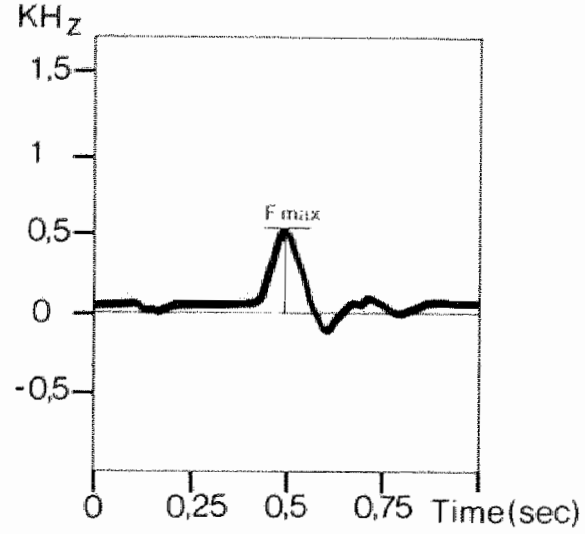

Preoperative

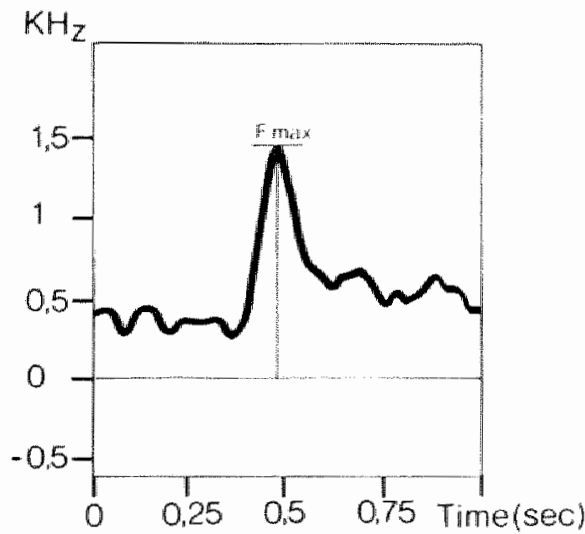

Postoperative

Figure X.1

Continuous Wave Doppler registrations. Fmax. is the peak forward ferquency (P.F.F.).

The peak forward frequency was measured before and after operation and at reexamination time. Mean follow-up was 7.0 years (range $4.0-11.5$ ).

Investigations were performed after acclimatisation at ambient room temperature for 15 minutes.

Signals of the non-operated side were used as a frame of reference.

To evaluate for statistical significance between two measurements the student-T-test was used. 


\section{X.3 Results}

In the group of patients with 'primary' operations, all patients claimed immediate improvement of their complaints after sympathectomy. An increase in peak forward frequency in ulnar and radial arteries was found after operation.

Table X. 1 shows the significant increase in P.F.F. on the operated side. On the nonoperated side there was no change in P.F.F.

Table X.1:

Increase in P.F.F, in radial and ulnar artery after primary operation (mean and standard error of the mean (S.E.M.) are given)

$\mathrm{N}=28 \quad$ operated side non-operated side

$\begin{array}{lll}\text { P.F.F.(Hz) before after } & \text { before }\end{array}$

(radial)

$\underbrace{1307 \pm 112} p<0.001-2160 \pm 186 \quad 1414 \pm 111 \quad L$ N.S.

P.F.F. (Hz)

(ulnar)

$$
1160 \pm 128 \quad \begin{aligned}
& 2000 \pm 163 \quad 1292 \pm 133 \\
& L
\end{aligned}<0.001 \stackrel{1346 \pm 140}{-} \text { N.S. }
$$

The possibility of a re-sympathectomy has been discussed in Chapter VIII. In 14 of these patients Doppler signals were available. Table X.2 presents the results in patients after a re-operation. The peak forward frequency in ulnar and radial arteries were significantly higher after re-sympathectomy. On the non-operated side used as a reference no change in ulnar or radial P.F.F. was found.

Table X.2:

Increase in P.F.F in radial and ulnar arteries after a re-sympathectomy (mean and

\begin{tabular}{|c|c|c|c|c|}
\hline \multirow[t]{2}{*}{$N=14$} & \multicolumn{2}{|c|}{ operated side } & \multicolumn{2}{|c|}{ non-operated } \\
\hline & before & after & before & after \\
\hline P.F.F. $(\mathbb{H z})$ & $1178 \pm 152$ & $1664 \pm 133$ & $1178 \pm 119$ & $1221 \pm 127$ \\
\hline (radial) & \multicolumn{2}{|c|}{$L_{-}<<0.001-$} & \multicolumn{2}{|c|}{ L N.S. $\longrightarrow$} \\
\hline P.F.F. $(\mathrm{Hz})$ & $858 \pm 140$ & $1433 \pm 161$ & $1041 \pm 210$ & $1075 \pm 169$ \\
\hline (ulnar) & \multicolumn{2}{|c|}{$\llcorner\mathrm{L}<0.001 \square$} & \multicolumn{2}{|c|}{$L$ N.S. $\longrightarrow$} \\
\hline
\end{tabular}
S.E.M. are given) 
Doppler studies were available for investigation in 34 of the 42 patients at re-examination time. In 6 patients an occluded ulnar artery was found at re-examination time, probably due to progression of disease. Table X. 3 shows the changes in peak forward frequency in the radial artery before and one week after sympathectomy and at re-examination time. Except for the expected increase in P.F.F. after sympathectomy a decrease in P.F.F. was found at re-examination time. On the non operated side no change in P.F.F. was found within one week postoperatively. At re-examination time a decrease in P.F.F. was found compared to the measurements before and immediately after operation.

At re-examination time $27 \%(9 / 34)$ of the patients were without clinical complaints. Of the 25 patients with clinical recurrences 9 claimed to be improved in relation to the preoperative state. In all patients the same trend of changes in P.F.F. was found. It was not possible to distinguish between the good, fair and poor results by continuous wave Doppler.

Table X3:

P.F.F. (Hz) of radial artery pre-and post operatively and at follow-up time (mean and S.E.M. are given)

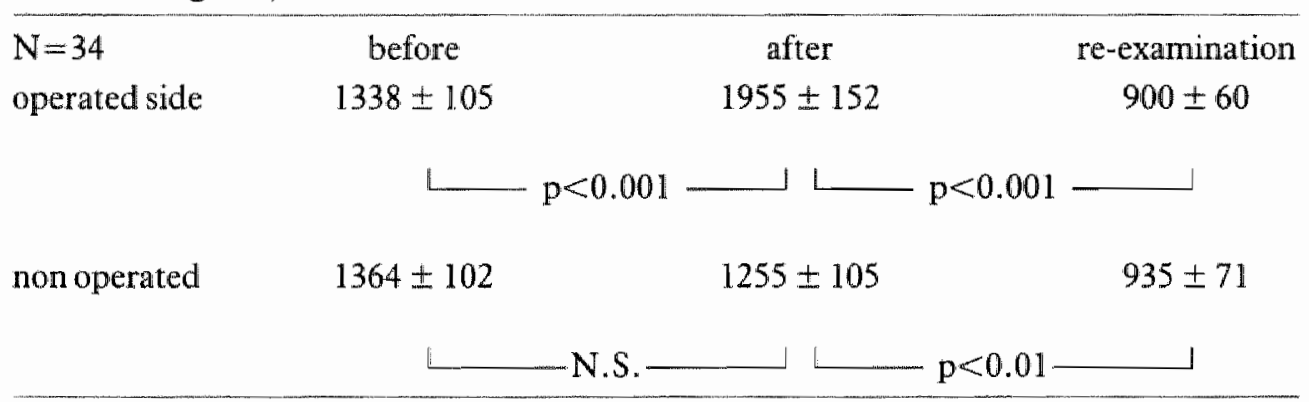

\section{X.4 Discussion}

The use of continuous wave Doppler as an objective method for evaluation of postoperative results and follow-up is an accepted investigation for the lower extremity. Quantitative Doppler studies of lower extremity flow velocity in healthy individuals and in patients with arterial obstruction have been presented by Fronek (42). Gosling (49) published his quantitative analysis of occlusive peripheral arterial diseases by a method which characterizes the shape of the Doppler wave-form in a single parameter; the pulsatility index. Bandyk (13) used quantitative Doppler signals to predict the graft patency after surgery. One of his parameters was the peak forward flow. Van de Wal (151) presented the results of quantitative Doppler studies in patients with Raynaud's phenomenon and in normal volunteers. He found that female patients with primary Raynaud's phenomenon could be discriminated from healthy persons by a decreased peak forward frequency in the radial and ulnar arteries. His explanation was an increase of peripheral resistance in patients with Raynaud's phenomenon. Arntz (5) found differences in several parameters in his quantitative Doppler study in patients with primary Raynaud's phenomenon compared to normal. All the parameters found were accepted as being characteristic of changes in peripheral resistance. One of these was the peak forward frequency. 
The results presented in this chapter show the possibility of quantitative Doppler studies especially the peak forward frequency in radial and ulnar arteries as an objective method for evaluation of the results immediately after sympathectomy. A significantly increased peak forward frequency was found in both arteries.

The effects of a re-sympathectomy have been presented in Chapter VIII. The immediate improvement claimed after re-operation could be verified by an increase in peak forward frequency. Table X.2 shows a significant increase in P.F.F. in ulnar and radial arteries after re-operation. Since Doppler studies are non-invasive and easy to perform, this technique seems to be a good alternative to the objective techniques for judging the postoperative results which were described in chapter II.6.

At re-examination time (mean follow-up 7.0 years) the peak forward frequency was decreased in all patients. The increased peak forward frequency in the immediate postoperative period had completely disappeared at re-examination time (Table X.3). Although $27 \%$ of the patients had no complaints and $73 \%$ had recurrence of their symptoms at re-examination time these groups could not be discriminated with the changes in peak forward frequency seen.

A possible explanation for these results on the-long term is the recovery of the intrinsic tone in the muscle of the vessel wall. Cannon (26) considered this question in 1937 and came to the conclusion that denervated smooth muscle can recover its tone as an intrinsic property.

Barcroft in 1952(16) described the change in peak flow several days after sympathectomy and showed increases of the order of five to twelve times the resting flow. This was followed by a gradual reduction in blood flow until, after a few weeks, the resting flow approached the preoperative level. Simeone (127) postulated in 1963 various explanations for the return of vascular tone, or increased resistence to blood flow after sympathectomy. The effects of changes in tension in the walls of the blood vessels seemed to be related to return of the vascular tone. On the long-term return of vasomotor activity may have been due to progression of the underlying disease or to regeneration of sympathetic fibres. In addition to these explanations the methodological limitations in monitoring may also affect the results presented. It is possible that newly available techniques, such as the spectral analyser with a bi directional continuous wave Doppler probe make differentiation of the results on the long term possible.

\section{X.5 Conclusions}

Based upon the data presented in this study, it might be concluded that the decrease in peripheral resistance following sympathectomy can be verified by an increase in peak forward frequency in the radial and ulnar arteries. 



\section{Chapter XI}

\section{General discussion and conclusion}

Sympathectomy for relief of ischaemic phenomena in the upper extremity has been complicated by a high percentage of recurrences.

The aim of this study was to evaluate the results of a new type of sympathectomy, the thoracodorsal sympathectomy 'en bloc'.

An extended technique was used, in the believe that an alternative pathway described by Kuntz (78) was mainly responsible for the disappointing results. By this technique an attempt was also made to prevent regeneration, another possible explanation for recurrences.

In addition to criticising the results, an analysis was made of the place of sympathectomy in patients with ischaemic hand phenomena.

After comparing the retrospective study with results of previous similar investigations, it must be concluded that the modified technique for sympathectony of the upper extremity, including resection of the second and third intercostal nerves and surrounding tissue did not yield the solution to the problem of the number of recurrences.

A point of discussion is the classification used for evaluating the results. No objective data are presently available for classifying the results on the long-term. Although it may be possible to differentiate subjectively between good and poor results, the interpretation of the patients who scored a fair result (return of complaints, but fewer compared to the preoperative state) is difficult. Should these patients be included in the overall successful results? In this study therefore the success rates (good results) are presented separately. Since the overall results are also influenced by the wide range of follow-up, and relapse of symptoms can be seen up to 5 years postoperatively, the life-table method of reporting results was introduced.

The results in patients with primary Raynaud's phenomenon in this study and the review of the literature make the role of a sympathectomy in these patients questionable. The overall success rate is disappointing and since the natural history is mild $(45,63)$ patients should be treated conservatively. The patients should have the natural history of their disease explained to them and special care must be taken in prevention, especially of cold provocation. Patients with secondary Raynaud's phenomenon on basis of progressive systemic sclerosis should also be treated conservatively. Plasma filtration (116) seems to be an alternative treatment in these patients. The thoracic sympathectomy should be reserved for cases in whom ischaemic fingers are at stake, in patients with primary as well as secondary Raynaud's phenomenon.

Most studies in patients with post-traumatic dystrophy claim good results after sympathectomy without clear classification of the patient's degree of disease. In this study the best results were obtained in patients with untreatable burning pain in the third stage of the disease. The place of sympathectomy in earlier stages is not clear nowadays because new hypotheses and rellated therapy give promising results $(48,53)$.

In patients with asphyxia the results after sympathectomy were good. Most patients could be relieved of their ischaemic pain, even on the long-term. In patients with threats of 
losing tissue from finger-tips or total fingers most could be spared. The satisfactory results can be explained through the mechanism of an improved collateral circulation.

The extensiveness of resection seems hardly to influence the results. A study of Baddeley has been described before (Chapter II). He found no differences in the long-term results after the various extents of the operations (10).

In spite of an extended resection the results in the presented study were almost equal to those in studies where only the sympathetic ganglia had been are resected. According to most authors $(93,97,106,108,150,153)$ the first, second and third thoracic ganglia need to be resected. In many patients the first thoracic ganglion is fused with the stellate ganglion (inferior cervical ganglion). To avoid Horner's syndrom only the lowest onethird must be removed in these patients (107).

In most patients an angiography of the upper extremity operated on was available for investigation. According to this study the value of angiography in patients with ischaemic hand phenomena was limited. The angiographical pathology found had no predictive value on which patients should benefit from sympathectomy, either immediately postoperatively or in the long term. No correlations between angiographic disturbances and clinical diagnosis or severity of complaints were found. Only in patients with asphyxia did angiography seem to be indicated in order to exclude pathology in the aortic arch or in its branches to the upper extremity which are surgically correctible.

Capillary microscopy with red bloodcell velocity measurements as routine investigation, is available in our hospital since 1985 . In combination with haemorrheological studies differentiation between the various ischaemic hand phenomena is possible $(63,64,91)$. This method makes a contribution to selecting patients who should respond favourably to thoracic sympathectomy.

The anatomical study with the great variability found in the connections between spinal and sympathetic nerve system shows, that prediction of results is difficult. The anatomical findings can differ from patient to patient independent of the clinical diagnosis. The presence of several sympathetic pathways as well as the previously described nerves of Kuntz and Kirgis which can bypass the sympathetic trunk, makes early relapse or no relief at all quite feasible. The perikarya found in these branches demonstrate the possibility of regeneration already mentioned by many authors. One can question whether a permanent and complete interruption of all sympathetic fibres to the upper extremity in fact can be accomplished by a thoracic sympathectomy.

The possibility of a re-sympathectomy has given further confirmation of the anatomical findings. The technique presented makes it possible to relieve most of the patients of recurrences of their complaints or in patients who did not react at all to the first operation to achieve an interruption of the sympathetic impulses to the upper extremity. However the results are also diappointing on the long-term.

The quantitative C.W. Doppler study was introduced in the hope of solving the problem of classifying the long-term results objectively. The Peak Forward Frequency (P.F.F.) in the distal ulnar or radial artery seemed to be a useful parameter for evaluating direct postoperative results objectively. A significant increase in P.F.F. was found after operation. In all patients the same trend of an increase in P.F.F. immediately after operations followed by a a decrease in P.F.F. on the long term was seen. In this study it was not possible to distinguish the good, fair or poor results by continuous wave Doppler. 
The thoracodorsal approach used, gives an excellent anatomical view of the sympathetic nervous system in relation to the intracostal nerves. It is an extrapleural route and the first to fourth sympathetic ganglia can easily be resected. Compared to other approaches the pulmonary complications are few because of the extrapleural approach. Few wound healing disturbances or wound infections are seen. A serious drawback of the posterior approach is the high morbidity, especially the longlasting pain around the scar and the back. The disturbance of anatomical coherence, by resecting a part of the third rib and its articulation with the transverse process and the vertebral body must be responsible for this phenomenon. In this study in $40 \%$ of the cases, patients still complained of this long lasting pain and had to be treated medically and by physiotherapy. The scar pain may be influenced positively by using a midline skin incision in stead of a paravertebral one. Since the long-term results were the same in studies where other approaches were used it is now questionable whether the thoracodorsal approach should be used.

The results of the present study lead to the following conclusions.

- The anatomical study shows that one can question whether a permanent, complete interruption of all sympathetic fibres can be accomplished by thoracic sympathectomy.

- The extended technique presented seems not to be the solution for the high precentage of relapses.

- If a thoracic sympathectomy is indicated the first, second and third thoracic ganglia should be resected. In cases of fusion of the stellate and first thoracic ganglia the lower third of the stellate ganglion should be resected.

- The indication for a sympathectomy of the upper extremity in patients with ischaemic hand phenomena is limited. In patients with primary or secondary Raynaud's phenomenon it should be reserved for special cases where fingers are at stake. In patients with post-traumatic dystrophy sympathectomy is indicated when conservative treatment has not been successful and relief of burning pain is desired in the later stage of the disease.

In patients with asphyxia, sympathectomy should be considered for those with severe ischaemic pain in the digits or those with early tissue necrosis. In these patients good results after sympathectomy can also be expected on the long-term.

- Angiography in patients with ischaemic hand phenomena is of limited value. Only in patients with the clinical symptoms of asphyxia, is angiography also in the provocative position indicated in order to exclude a surgically correctable lesion in the aortic arch or in its branches to the upper extremity.

- Because of the high frequency of scar and back pain the thoracodorsal approach should be saved for special cases where transpleural approaches are contra-indicated.

- A special place for the Thoracodorsal Sympathectomy 'en bloc' is in patients in whom a re-sympathectomy is indicated. The excellent anatomical view, especially of the intercostal nerves, who need to be resected make a re-operation easy. 



\section{Chapter XII}

\section{Summary}

Thoracic sympathectomy is complicated by a high percentage of relapses. The source of this problem is still unsolved although many explanations has been given. One of the explanations is the anatomical variation of the high thoracic sympathetic nervous system in relation to the spinal nervous system. The intrathoracic nerve described by Kuntz is a possible explanation, since sympathetic fibres can run along this nerve and bypass the sympathetic trunk. The aim of this study was to evaluate the results of a modified thoracic sympathectomy, the thoracodorsal sympathectomy 'en bloc', in patients with ischaemic hand phenomena. This extended operation technique should also interrupt the sympathetic fibres extant in the intrathoracic nerve described by Kuntz.

By an evaluation of results in combination with an anatomical study, angiography and continuous wave Doppler the place of the sympathectomy in these patients is analysed.

In Chapter II the literature of the thoracic sympathectomy is reviewed and many techniques for interrupting the sympathetic impulses to the upper extremity are presented. The various approaches to the sympathetic chain and their advantages and disadvantages are discussed. In spite of a frequent change in operative techniques relapses have been seen. The explanations given in the literature for these failures are presented. Finally the methods used for evaluation of the presence or absence of sympathetic activity are described.

In Chapter III the patients and their clinical classification are presented.

The preoperative value of angiography is described in Chapter IV. There seens to be only a limited place for routine angiographic investigations in patients with ischaemic hand phenomena. The angiographic abnormalities do not correlate with the clinical diagnosis. Furthermore, no correlation is found between the severity of the complaints and the angiographic signs. Only in patients with clinical symptoms of asphyxia is angiographic investigation of the extremity necessary to exclude surgically correctable proximal lesions.

In Chapter V the surgical technique of the thoracodorsal sympathectomy 'en bloc' is presented. The technique used for a re-sympathectomy, when only the sympathetic ganglia are removed in a previous operation, is described.

An anatomical study of resection preparations is presented in Chapter VI. The variation in the anatomy of the upper thoracic sympathetic nervous system in relation to the spinal nervous system is more extensive than has been described up to now. There is a network of a few or several nerve bundles with various diameters. In a large number of these nerve bundles perikarya are found. Consequently, there is a possibility that in a sympathectomy, for the purpose of interrupting all vasomotor and sudomotor impulses to the upper extremity some tiny fibres are left untouched and that they are able to take over the function of the resected nerve bundles. Furthermore central axon stump may form nerve sprouts which make contact with the peripheral stumps growing out along them and thus forming new sympathetic pathways. 
In Chapter VII the results of this retrospective study are presented in relation to the clinical diagnosis. Comparing the results with those of studies in the literature, one must conclude that the extended sympathectomy does not give the desired results. In addition to the method generally used in the literature for reporting results, in this study the results have been determined by the life-table method. The success rates (good results) are presented separately by this method but the overall results are disappointing. It is questionable whether patients with primary Raynaud's phenomenon should be treated at all by sympathectomy since relapses are frequently seen and the natural history is mild in most patients.

In patients with secondary Raynaud's phenomenon, thoracic sympathectomy should be reserved for severe cases where fingers are at stake.

In patients with post-traumatic dystrophy there is, however a place for sympathectomy, especially in relief of the burning pain. In the early stages of post-traumatic dystrophy the usefulness of a sympathectomy is not clear, since treatment with regional intravenous guanethidine or hydroxyl radical scavengers show promissing results. In the later stage of disease good results in relation to pain have been obtained. No influence on functional improvement should be expected in this stage.

The patients with asphyxia respond favourably to sympathectomy. Not only can amputation of parts of fingers be prevented but also patients are relieved of their ischaemic pain, probably due to improvement in the collateral circulation.

Because of its extrapleural exposure the thoracodorsal sympathectomy seemed to be preferable to the various transthoracic approaches. Fewer pleurals complication were found compared to other studies. A serious draw-back to this posterior approach is the longlasting pain in the scar and back: many patients complained for several years after this operation. Since the results of other approaches are identical to those of the thoracodorsal approach, it should be saved for special occasions.

In Chapter VIII the possibility of a re-sympathectomy is discussed. In patients in whom only the sympathectic ganglia were previously been resected with transient success, a resympathectomy effect can be achieved. The thoracodorsal approach seems to be the proper way to perform this operation. It is an extra-pleural approach and the intercostal nerves which have to be resected are easily exposed. The results after a re-sympathectomy are almost equal to those after the 'primary' operation. The conclusions must be that resympathectomy is possible by the technique described but should be reserved for special indications, when digits are threatened.

In Chapter IX the predictive value of angiography in selecting patients for sympathectomy is discussed. No correlation has been found between angiographic disturbances and postoperative results. Also the results on the long-term are not predictable from the angiographic signs.

In Chapter X a quantitave continuous wave Doppler study to evaluate postoperative results is presented. There seems to be a place for the continuous wave Doppler to judging direct postoperative results, since the decrease in peripheral vascular resistance after sympathectomy can be verified by an increase in peak forward frequency in ulnar and radial arteries.

In the final Chapter (XI) the results from the previous chapters are discussed and some conclusions are drawn. 


\section{Chapter XIII}

\section{Samenvatting}

Een groot probleem van de thoracale sympathectomie is het hoge recidief percentage. Ondanks vele theoretische beschouwingen is hiervoor tot op heden geen eensluidende verklaring gevonden. De grote variatie in anatomische verbindingen tussen het hoog thoracale sympathische en spinale zenuwstelsel wordt in vele gevallen als oorzaak gezien. De intrathoracale zenuw beschreven door Kuntz is een mogelijke verklaring, omdat via deze zenuw sympathische vezels de sympathische grensstreng kunnen passeren.

Het doel van deze studie was een nieuwe operatie techniek, de thoracodorsale sympathectomie 'en bloc' retrospectief te evalueren bij patienten met ischaemische hand fenomenen. Door middel van deze uitgebreide resectie wordt de door Kuntz beschreven zenuw met sympathische vezels welke de grensstreng kunnen passeren, gereseceerd. Met behulp van een kritische anlyse van de resultaten, voorafgaand door een gedetailleerde anatomische studie, in combinatie met angiografisch-en continuous wave Doppler onderzoek wordt het indicatie gebied voor een sympathectomie in deze patienten geanalyseerd.

In Hoofdstuk II wordt de geschiedenis van de sympathicus chirurgie beschreven, en een overzicht gegeven van de literatuur betreffende de verschillende operatietechnieken om sympathische impulsen naar de bovenste extremiteit uit te schakelen. De verschillende operatieve benaderingswijzen naar de sympathische grensstreng met hun voor-en nadelen worden beschreven.

Ondanks al deze toegepaste operatie technieken blijven recidieven bestaan. De hiervoor in de literatuur beschreven verklaringen worden besproken. In dit hoofdstuk wordt tot slot een overzicht gegeven van gebruikte instrumenten en technieken om aan- of afwezigheid van sympathicus activiteit te objectiveren.

De verschillende categoriën patienten welke in deze studie werden geanalyseerd worden beschreven in Hoofdstuk III.

De pre-operatieve waarde van de angiografie in de geanalyseerde patientengroep wordt in Hoofdstuk IV geevalueerd. Het bliikt dat de waarde van de angiografie bij ischaemische hand fenomenen gering is. Er bestaat geen relatie tussen de ernst van de klachten en de angiografische afwijkingen. Het indicatie gebied voor angiografie beperkt zich tot patienten met het klinische beeld van asphyxia om proximaal gelegen laesies welke chirurgische interventie nodig kunnen maken uit te sluiten.

In Hoofdstuk V wordt de operatie techniek van de thoracodorsale sympathectomie 'en bloc' beschreven. De techniek van een re-sympathectomy wordt eveneens beschreven. Deze is toepasbaar bij patienten waarbij tijdens voorafgaande operatie alleen de bovenste thoracale ganglia zijn verwijderd.

Een anatomische studie van het operatiegebied, aan de hand van resectiepreparaten wordt gepresenteerd in Hoofdstuk VI. Het blijkt dat de anatomische variaties in verbindingen tussen het sympathische en spinale zenuwstelsel nog talrijker is dan tot nog toe werd verondersteld. Er blijkt een netwerk van grotere en kleinere vezels te bestaan. In vele van 
deze zenuwvezels werden zenuwcellichamen (perikarya) gevonden. Deze gevonden anatomische variaties maken het mogelijk dat na een sympathectomie met de bedoeling alle vasomotore en sudomotore impulsen naar de arm te onderbreken, vezels intact blijven welke de functie van de gerseceerde vezels kunnen overnemen. De aangetoonde zenuwcellichamen kunnen, als deze tijdens een sympathectomie ongemoeid gelaten worden, via uitgroei van zenuwvezels in contact komen met gedecentraliseerde axonen en hierin uitgroeien zodat nieuwe banen ontstaan waarlangs sympathische impuisen naar de arm weer mogelijk worden.

In Hoofdstuk VII worden de resultaten van de retrospectieve studie van de in Hoofdstuk $V$ besproken techniek beschreven. De resultaten worden beschreven in relatie tot de klinische diagnose. Na vergellijking van de resultaten met andere studies uit de literatuur blijkt dat de titgebreide resectie van sympathische ganglia en intercostaal zenuwen en het omringende weefsel 'en bloc' geen betere resultaten geeft. Behalve de in de literatuur gebruikte methode om de resultaten weer te geven, wordt in deze studie de life-table methode gebruikt. De als goed geklassificeerde resultaten worden op deze manier afzonderlijk weergegeven. Deze ziin direct postoperatief hoopvol maar op de langere termijn teleurstellend. Gezien deze matige resultaten lijkt een sympathectomie bij patienten met een primair Raynaud's fenomeen niet geindiceerd. Vooral gezien het grote recidief percentage en de in het algemeen milde verloop van de ziekte. Bij patienten met een secondair Raynaud's phenomeen is het aan te bevelen de sympathectomie te reserveren voor die ernstige gevallen waar overleving van vingers of delen hiervan op het spel staan.

Bij patienten met een post-traumatische dystrofie blijkt er een indicatie voor sympathectomie, vooral ter bestrijding van de brandende pijn. De plats van de sympathectomie in een vroeg stadium van het ziektebeeld is niet duidelijk vooral daar recent ontwikkelde medicamenteuze behandelingen veel belovende resultaten laten zien. Vooral in een laat stadium van de ziekte waar conservatieve therapie zonder resultaat is, reageert de pijn goed op een sympathectomie. De functionele verbetering in dit stadium zal gering ziin.

In de groep patienten met asphyxia zijn de resultaten van de sympathectomy goed. Niet alleen kan amputatie van gedeelten van vingers worden voorkomen, ook worden de patienten verlost van hun ischaemische pijnen. Een verklaring voor de goede resultaten in deze groep moet de verbeterde collaterale circulatie zijn.

Een technisch voordeel van de thoracodorsale sympathectomie 'en bloc' is de extrapleurale benaderingswijze. Dit komt tot uiting in het lagere percentage pulmonale complicaties in vergelijking met studies betreffende transthoracale technieken. De veel voorkomende langdurige pijnen ter hoogte van het litteken en/of de rug ten gevolge van de resectie van een gedeelte van de $3 e$ rib en de processus transversus van de derde thoracale wervel vormen een ernstig probleem.

Aangezien gebleken is dat de resultaten van de thoracodorsale sympathectomie 'en bloc' in vergelijking met de literatuur niet beter zijn dan na andere benaderingswijzen, lijkt er alleen in speciale gevallen een plaats te zijn voor de posterieure benadering en de 'en bloc' resectie.

In Hoofdstuk VIII wordt de mogelijkheid van een re-sympathectomie beschreven. Het blijkt dat bij patienten waar in een voorafgaande operatie alleen sympathische ganglia zijn verwijderd zonder of met voorbijgaand resultaat een re-sympathectomie effect kan 
worden verkregen. De thoracodorsale benadering lijkt hiervoor de aangewezen techniek. Het is een extrapleurale benadering en er wordt een uitstekend anatomisch chirurgisch overzicht verkregen over de intercostaal zenuwen, welke moeten worden gereseceerd. De resultaten op de lange duur blijken overeen te komen met de beschreven 'primaire' operatie. De uiteindelijke conclusie is dat het mogelijk is om een re-sympathectomie effect te verkriigen met de beschreven techniek. Het indicatiegebied is klein.

In Hoofdstuk IX wordt de voorspellende waarde van de angiografie voor goede resultaten na sympathectomie besproken. Er blijkt geen correlatie te bestaan tussen angiografische bevindingen en de postoperatieve resultaten. Ook de resultaten op de langere termijn blijken niet voorspelbaar aan de hand van de angiografische afwijkingen.

In Hoofdstuk X wordt de waarde van de continuous wave Doppler als meetinstrument voor postoperatieve resultaten besproken. Een quantitatieve studie van Doppler signalen en resultaten worden gepresenteerd. Het lijkt dat quantitative analyse van continuous wave Doppler signalen een goede methode is voor beoordeling van het slagen van een sympathectomie. De te verwachten verlaging van de perifere weerstand na een sympathectomie wordt ondersteund door een significante toename van de peak forward frequency in zowel de arterie radialis als ulnaris.

In het laatste Hoofdstuk (XI) worden de resultaten,zoals beschreven in de voorafgaande hoofdstukken, geevalueerd waarna enige conclusies worden getrokken. 



\section{References}

1. Adar Ar, Kurchin A, Zweig A, Moses M Palmar hyperhydrosis and its surgical treamen Ann. Surg. 1.97\%; 186: 34-41

2. Adson A.W., Brown G.E., The treatment of Raynaud's disease by resection of the upper whoracic and lumbar sympat thetic ganglia and trunks. Surg. Gynecol, Obstet. 1929; 48:577-603

3. Adson A.W., Physiologic effects produced by ablation of the autonomic central influence Various form of sympathectomy in treatment of diseases. Surgery 1963; 13:425-453

4. Alexander W., The treatment of Epilepsy. $220 \mathrm{pp}$. Edinburgh; Pentland 1889

5. Arntz I.E., van de Wal H.J.C.M., Wijn P.F.F., Skotnicki S.H., Quantitative assessment of vasospasm by Doppler spectrum analysis in patients with primary Raynaud's phenomenon. Eur. J. Vase. Surg. 1987; 1: $19-28$

6. Ascroft P.B., The basis of treatment of Vasospastic States of the extremiries; an Experimental Analysis in Monkeys. Brit. J. Surg. 1937; 24: 787-816

7. Atkins H.J.B., Peraxillary approach to the stellate and upper thoracic sympathetic ganglia. Lancer 1949: 1152

8. Atkins H.J.B., Sympathectomy by the axillary approach. Lancer 1.954; I: $538-540$

9. Atlas L.N., The role of the second thoracic spinal segment in the preganglionic sympathetic innervation of the human hand-surgical implications. Ann. Surg. 1941; 114:456-461

10. Baddeley R.M., The place of upper dorsal sympathectomy in the reatment of primary Raynaud's discase. Br. J. Surg. 1965; $52: 426-430$

11. Balas P., Tripolites A., Upper thoracic sympathectomy on systemic scleroderma. Vasc. Surg . 1974;8. 234-237

12. Baljet B., and Drukker J., An acethylcholinesterase method for staining of peripheral nerwes. Stain Technol. 1975; 50:31.36

13. Bandyk D.F., Cato R.F., Towne J.B., A low flow velocity predicts failure of femoropopliteal and femorotibial bypass grafts. Surgery 1985; 89: 799-809

14. Barcroft H., Hamilton G.T.C., Further observations on the results of sympathectomy of the upper limb. Lancer 1948; 1: $770-771$

15. Barcroft. H. Walker A.J., Return of tone in blood vessels to the upper limb after sympathectomy. Lancet 1949; 1: 1035-1039

16. Barcroft H., Problems of sympathetic innervation and denervation. Br. Med. Bull. 1952;8: 839-843

17. Bennet R., Bluestone R., Holt R.J.L., Bywaters E.G.L., Survival in scleroderma. Am. Rheum. Dis. $1971 ; 30 \div 581-588$

18. Bergan J.J., Conn Jr. J., Trippel O.M., Severe ischemia of the hand, Ann of Surg. 1971; 1.73: 301 307

19. Berguer R., Smit R., Transaxillary sympathectomy (T2 to T4) for relicf of vasospasuic/sympathetic pait of the upper extreminies. Surgery 1981; 89: 764-769

20. Bernard M.C., De l'influence du systeme nerveux grand sympathique sur ta chalcur animale. C. R. Achd. Sci. $1852 ; 43: 472-475$

21. Birnstingl M., The Raynaud's syndrome Postgrad. Med. J. 1971:47:297-310

22. Blain A., Coller F.A., Carver G.B., Raynaud's diseast, a study of criteria for progriosis. Surgery 1951; 29 ; $387-397$

23. Bloor K, Gustatory sweating and other responses after cervico-fhoracic sympanthectomy. Bran 1969; 92 : $137-146$

24. Brüning F., and Stah1 O., Die Chirurgie des Vegetativen Nerven-sysiems. Berlin؛ Springer, 1924.

25. Brunner U.V., Fischer B., Fischer F., Aspekte der oberen thorakalen Sympathektomic. Angio 1980;2,2: $119-125$

26. Cannon W. B., Factors affecting vascular tone. An Heart J. 1937; 14: 383.398

27. Chamberlain J., Macpherson A.I.S., Cervicodorsal sympathectomy for Raynaud's syndromi. J R. Coll. Surg. Edinb. 1974; 4: 228-232

28. Cohen S.M., The place of sympathectomy in peripheral wascular disease. Ann. R. Coll. Surg. Fngl. 1953; $1296-116$

29. Colon K.C., Keaveny T.V., Upper dorsal sympathectomy for palmar hyperhidrosis. Br. J. Surg. 1987; 74: 651 
30. Cyon H., Cyon E., Ueber die Innervation des Herzeris won Rüchesmarke aus. Centr. B1. Med. Wiss. (Berlin) 1866;51:801-805

31. Dabich L., Bookstein J.J., Zureifler A, Zarafonetis C.J.D., Arbor A., Digital arteries in patients with scleroderma. Arch. Intarn Med. 1972; 130:708-714

32. Dale W.A., Raynaud's phenomenon due to arterial occlusive disesse of the wrist and hand. J. Tenn. Med. Ass. 1976; Jan: 22-28

33. Dass R., Sympat thenic components of the dorsal primary division of human spinal nerves. Anat. Rec. 1952; 113: $493-501$

34. Drucker W.R., Hubay C.A., Holden W.D., Bukovnic J.A., Pathogenesis of post-1raumatic sympathetic dystrophy Am J. Surg. 1959; $97: 454-465$

35. Duff R.S., Effect of adrenaline and noradrenaline on blood vessels of the hand before and after sympathectomy. J. Physiol. 1955; 129:53-64

36. Dunningham T.H., The treatment of Sudeck's dystrophy in the upper limb by sympathetic blockade. Injury. 1980; 12:139-144.

37. Farmer R.G., Gifford R.W., Hines E.A., Prognostic significance of Raynaud's phenomenon and other characteristics of systemic scleroderma. Circulation 1960; 21: 1088-1095.

38. Fatherree T.J., Adson A.W., Allen E.V., The vasoconstrictor action of epinephrine on the digital arterioles of man before and after sympathectomy. Surgery 1940; 7:75-94

39. Felder D.A., Simeone F.A., Linton R.R., Welch C.E., Evaluation of sympathetic netrectomy in Raynaud's disease. Surgery 1949; 26: 1014-1033

40. Freeman N.E., Smithwick R.H., White J.C., Adrenal Secretion in man; the reactions of the blood wessels of the human extremity, sensitized by sympathectomy, to adrenalin and to adrenal sectetion resulting from insulin hypoglycemia.

Am. J. Physiol. 1934; 107:529-534

41. Fretheim B., Sympatheric denervation of the upper extremities in Raynaud's disease and secondary Raynaud"s phenomenon. Acta. Chir. Scand. 1961; $122: 361-370$

42. Fronek A., Coel M., Bernstein E.F., Quantitative ultrasonographic studies of lower extremity flow velocities in heath and disease. Circulation 1976;53:1957-1960

43. Gary T.P., Henry A.K., Anterior uranscostal access to upper parts of the sympathetic chain. Irisch. J. Med. Sci. $1949 ; 6: 757-761$

44. Gask G.E., The surgery of the sympathetic nervous system. Br. J. Surg. 1943; 21: 113-130

45. Gifford R.W., Hines E.A., Raynaud's disease among women and girls. Circulation 1957; 16: 1012-1021

46. Gifford R.W., Hines E.A, Graig W.K., Sympathectomy for Raynaud's phenomenon (follow-up study). Circulation 1958; 17:5-13

47. Goetz R.H. and Man J.s., The importance of the second thoracic ganglion for the sympathetic supply of the upper extremity. Clin. Proc. (Cape Town), 1944; 3: 102-107

48. Goris R.J.A., Trestment of Reflex Sympathetic Dystrophy with Hydroxyl Radical Scavengers. Unfalltchirurg 1985; 88: 330-332

49. Gosling R.C., Dunbar G., King D.H., The quantitative analysis of occlusive peripheral arterial dusease by a non-intrusive ultrasonic technique. Angiology $1971 ; 22: 52-55$

50. Grant R. T., Further observations on the vessels and nerves of the Rabbit"s ear. With special reference to the effect of denervation. Clin. Sci. 1935; 2:1-33

51. Groen G.J, Contributions to the Anatomy of the Peripheral Autonomic Nervous System. Thesis University of Ansterdam 1986.

52. Hall K.V., Hillestad L.K., Raynad's phenomenon treated with sympatheclomy. A follow-up study of 28 patients. Angiology 1960; 11: 186-189.

53. Hannington-Kiff J.G., Relief of Südeck's atrophy by regional intravenous guanethidine. Lancet 1977 ; i, 1132-1133.

54. Haxton H.A. Treament of hyperliydrosis. Br. Med. J. 1948; 1: 636-638

55. Haxton H.A., The sympathetic nerve supply of the upper limb in relation to sympathectomy. Ann. R. Coll. Surg. Engl. 1954; 14: 247-266

56. Haxton H.A., Upper limb resympathectomy. Br. J. Surg, 1970; 57: 106-108

57. Haxton H.A., The technique and results of upper limb sympathectomy. J. of Cardiovase. Surg. 1970; 11: $27-34$

58. Henry A.K., A new method of resecting the left cervioodorsal ganglion of the sympathetic in angina perctor is. Irish J. Med. Sci. 1924; 5: 157-159. 
59. Hunter J.I., The infuence of the sympathetic nerwous system in the genesis of the rigidity of striated muscle in spastic paralysis. Surg. Gynec. Obstet. 1924; $39: 721.743$

60. Hyndman O.R., Wolhin J., Sweat mechanism in man. Arch. Neurol and Psych. 1941; 45: 446-467

611. Hyndman O.R., Wolkin J. Sympathecromy of the upper extremity. Arch. Surg. 1942; 145: 145-155

62. Jaboulay M., Le Traitement de quelques troubles trophique du pied et de la jambe par la dénadation de l"artère femorale et la distension des nerfs vasculaires. Lyon Med. 1899; 91 : 467-471

63. Jacobs M.J.H.M., Capillary microscopy and haemorheology in vasospastic and occlusive vascular disease. Thesis, University of Maastricht, 1985

64. Jacobs M.J.H.M., Breslau P.J., Slaaf D.W., Reneman R.S., Lemmens H.A.J., Nomenclarure of Raynaud's phenomenon. A capillary microscopic and haemorhologic study. Surgery 1987; 101: 136-145

65. Janewski B., Angiography of the upper extremiry. Martin Nijhof Publ. The Hague Boston London 1982

66. Janevski B., Arteries of the Hand in Patients with Scheroderma. Diag. Imag. Clin. Med. 1986; 55: 262-265

67. Jepson R.P., Raynaud's phenomenon-a review of the clinical problem. Ann. R. Coll. Engl. 1951;9:35-51

68. Jeune $\mathbb{R}$., Thivolet J., Etude arteriographique de la main au cours de 52 phenomènes de Raynaud d'étiologie diverse. Nouv. Presse Méd. 1978; 7: 2619-2623

69. Jochismen P.R., Hartfall W.G., Per axillary upper extrennity sympathectomy. Technique reviewed and clinical experience. Surgery 1972; 71:686-693

70. Johnston E.N.M., Summerly R., Birnstingl M., Prognosis in Raynaud's phenomenon after sympathectomy. Brit. Med. J. 1965; 1: $962-964$

71. Jonnesco M.T., La résection totale et bilaterale du sympathique cervical. Ann Oculistique 1896; 117:161175

72. Kent S.J.S., Lea Thomas M., Browse N.L., The value of arteriography of the hand in the Raynaud's syndrome. J. Cardiovase. Surg. 1976; 17:72-80

73. Kirgis H.D., Kuntz A., Inconstant sympatheric neural parhways. Arch. Surg. 1942; 44:95-102

74. Kirgis H.D., Ohler E.A., Regeneration of pre and postganglionic fibers following synpathectomy of the upper extremity. Ann. Surg. 1944; 119:201-210

75. Kleinert H.E., Cook F.W., Kutz J.E., Neurovascular disonders of the upper extremity. Arch Surg. 1965; 90: $612-616$.

76. Koikkalainen K., Luosto R., Keskitalo E., Melartin E., Upper limb symparhectomy. Arn. Chir. Gynaecol. 1974; 63: 318-325

77. Kramer J.G., Todd T.W., The distribution of nerves to the arteries of the arm with a discussion of the clinical value of results. Anat. Rec. 1914; 8: 243-255.

78. Kuntz A., Distribution of the sympathetic rami to the brachial plexus. Arch. Surg. 1927; 15: 871-877

79. Kuntz A., Alexander W.F., Furcolo C.L., Complete sympatheric denervation of the upper extremity. Ann. Surg. 1938; 107: 25-31

80. Kux E., Thorakoskopische Eingriffe am Nerven-System. Stuttgart, Georg Thieme Verlag, 1954

81. Kux E., Thoracic endoscopic sympathectomy in palmar and axillary hyperhydrosis. Arch. Surg. 1978; 113: 264-266

82. Langley J.N., Preliminary account of the arrangement of the sympathetic nervous system based chiefly on observations upon pilomotor nerves. Proc. R. Soc. Lond. 1893; 52: 547-556

83. Laubach K., Linder F., Piotrowski L., Thorakale ransaxillare sympathektomie. Disch. Med. Wschr. 1972; $97: 745-749$

84. Laws J.W., Lillie J.G., Scott J.t., Arteriographic appearances in rheumatoid arthrints and oiher disorders. Arthritis Rheum. 1963; 36:477.493

85. Lee B.J., Castillo H.T, Madden J.L., Quanufication of the arterial pulsatile blood flow wave form in peripheral vascular disease. Angiology 1970;21:595-605

86. Lee F.C., Regeneration of nervous tissuc. Physiol. Rew. 1929; 9: 575-623.

87. Lemmens H.A.J., Nomenclature of ischaemic hand syndromes. Raynaud's phenomenon. TM Verlag Ed Heidrich H. Berlin 1979; 19-23

88. Lemmens H.A.J., Thoracodorsal sympathectomy "en bloc". Vase. Surg. 1979; 13: 331-335

89. Lemmens H.A.J., Thoracic Resympathectomy. Int. Angiology 1982; 1: 147-148

90. Lemmens H.A.J., Importance of the second thoracic segment for the sympathetic denervation of the hand. Vasc. Surg. 1982; 16:23-26

91. Lemmens H.A.J., Historical review of Raynaud's phenomenon nomenclarure and pathophysiology. Vasa 1987; Supp. 18: 10-14. 
92. Leriche he De lielongation et de la section des nerfs periwasculaires dans certain syndromes douloureux d'origine arterielle et dans quelques troubles trophiques. Lyon Chir. 1913; 10:378-382

93. Linder F : Jenal G., Assmus H., Axillary Transpleural Sympathectomy: Indication, Technique and Results. World J. Surg. 1983;7:437-439

94. Little J.M., May J., A comparision of the supraclavicular and axillary approaches to the upper thoracic sympathectony. Aust. NZ. J. Surg. 1975; 45: 143-146

95. Lowe J.G., Juergens J.L., Second thoracic sympathetic ganglionectomy for neurologic and vascular. disturbances of the upper extremities. West. J. Surg. Obst. Gynaec. 1964; 72:130-133

96. Lynn R.B., Steiner R.E., Wyck wan F.A.K., Arteriographic appearances of the digital arteries of the hands in Raynaud's disease. Lancet 1955; 1:471-474

97. Manart F.D., Sadler T.R., Schmitt E.A., Rainer W.A., Upper dorsal Sympathectomy Am. J. Surg. 1985; 150: $762-766$

98. Mattassi R., Miele F., d'Angelo F., Thoracic sympathectomy. Review of indications, results and surgical techniques. J. Cardiovase. Surg. 1981;221:336-339

99. McAnamara M.F., Takaki H.S., Yao J.S.T., Bergan J.J., A systemic approach to severe hand ischemia. Surgery $1978 ; 83: 1-11$.

100. Menanteau B., Treutenaere J.M., Marcus C., Ladam V., Bonnet F., Données de l'arteriographie dans les ischemies chroniques de la main. J. MaL. Vasc. (Paris) 1986; 11: 3l-34

101. Metz L., Waigard J., Eggebnisse der Thorakalen Sympathektomie beim Raynaud Syndrom. Z. Artzl. Fortbild. 1977; 71:780-783

102. Milewski P.J., Hodgson A.S.P., Higham, A., Transthoracic endoscopic sympathectomy. I. R. Coll. Surg. Edinb. 1985; $3: 221 \cdot 223$.

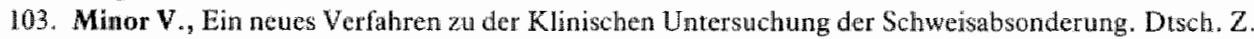
Nervenh. 1927; 103: 302-308:

104. Mitchell A.G., Anatomy of the Autonomic Nerwous System. Edinburgh: Livingstone, 1.953.

105. Monro P.A.G., Sympathectomy. London: Oxford Uniw. Press, 1959.

106. Montorsi W., Ghixinghelli C., Annoni F., Indication and results of the surgical treatment in Raynaud's phenomenon. J. Cardiovasc Surg. 1980; 21: 203-210

107. Palumbo L.T., Anterior Transthoracic Approach for upper thoracic sympathectomy. Arch. Surg. 1956; 72: 659-666

108. Palumbo L.T., Lulu D.J., Transthoracic upper dorsal sympathectony. Surgery 1963;53:563-566

109. Patman R.D., Thompson J.E., Persson A.V., Mangement of Post-traumatic Pain Syndromes. Ann Surg. 1973; 177; 780-787

110. Peacock J.H., The treatment of primary Raynaud's disease of the upper limb. Lancet 1960; i: 65-68

111. Pick J., Sheehan D., Sympathetic rami in man, J. Anat. 1946;80: 12-20

112. Pick M.D., The Autonomic Nervous System. Philadelphia/Toronto: Lippincott, 1970.

113. Porter J.M., Snider R.L., Barbana E.J., Rösch J., Eidemiller L.R., The diagnosis and treatment of Raynaud"s phenomenon. Surgery 1975;77;11-23

114. Ray B.S., Sympathectomy of the upper extremity. Evaluation of surgical methods. J. Neurosurg. 1953, 10: $624-633$

115. Rettori R., Arteriopathies de la main et syndrome de Raynaud. J. Mal. Vase. (Paris) 1979; 4:31-35

116. Van Rhede van der Kloot E.J.H., Jacobs M.J.H.M., Weber H., Lemmens H.A.J., Plasma liltration in patients with Raynand's phenomenon. Clin. Haemorheology 1985; 4: 79.84

117. Richter C.P., Instructions for using the cutaneous resistance recorder, or Dermometer on peripheral nerve injuries, sympathectomies, and paravertebral blocks. J. Neurosurg. 1946; 3: 181-19l

118. Richter-v Arnauid H.P., Funktionelle Diagnostik mit der direktionalen Doppler-Untersuchung bein Raynaud-Syndrom. Med Klin. 1979; 74: 1391-1395.

119. Ring F.F.J., Porto L.O., Bacon P.A., Quantitative Thermal Imaging to Assess Inositol Nicotinate Treatment for Raynaud's Syndrome. J. Int. Med. Res. 1981; 9: 393-400

120. Rittenhouse W.A., Maixner W., Burr J.W., Barnes R.W., Directional arterial flow velocity: A sensitive index of changes in peripheral vascular resistance. Surgery 1976; 79:350.355

121. Rösch J., Porter J. M., Gralino B.J., Cryodynamic hand angiography in the diagnosis and management of Raynaud's syndrome. Circulation 1977; 55: 807.814

122. Royle N.D., A new operative procedure in the treatment of spastic paralysis and its experimental basis. Med. J. Aust. 1924;1:77-81 
123. Schulz U.y Jenal G., Erfahrungen mit der thorakalen Sympathektomic bei peripheren arteriellen durchblutungsstorungen der oberen extremitat. Angio 1980; 2: 137-140

124. Sebesteny M., Mogan I., Papp S., Szabo J., Soltesz L., Spätergebnisse der Thorakalen Symparhekromic

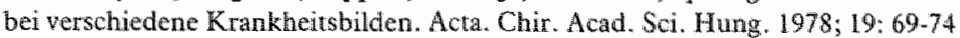

125. Servelle M., Turpijn H., Cornu C., Dalisson M., Grimberg F. Arteriolite des doigts et maladie de Raynaud. Coenr Med. Interne 1963; 2: 383-393

126. Simeone F.A., Felder D.A., The supersensitivity of denervated digital blood vessels in man. Surgery $1951 ; 10 \% 218-226$

127. Simeone F.A., Intravascular pressure, vascular tone and symparthectomy. Surgery $1963 ; 53: 1 \cdot 18$

128. Simmons H.T., Sheehan D., The causes of relapse following sympathectomy of the arm. Br. J. Surg. $1939 ; 27: 234-235$

129. Skoog T, Ganglia in the communicating rami of the cervical sympathetic trunk. Lancet 1947; I: $457-460$

130. Smithwick R.H., Modified dorsal symparhectomy for vascular spasm (Raynaud's disease) of the upper extremity. Amn. Surg. 1936; 104:339-350

131. Smithwick R.H., The problem of producing complete and lasting sympathetic denervation of the upper extremity by preganglionic section. Ann. Surg. 1940;112: 1085-1100

132. Smithwick R.H., The rational and technic of sympathectomy for the relief of vascular spasm of the extremities. New Engl. J. Med. 1940; 222:699-703

133. Spelbar M.J., Rosentahal D., Collins G.J., Jarstfer B.S., Walters M.J., Changing trends in causalgia. Am J Surg 1981; 142: 744-746.

134. Spurling R.G., Causalgia of the upper extremiry. Arch. of Neurol. and Psych. 1930;23:784-788

135. Steinbrocker O., Spitzer N., Friendman H.H., The shoulder-hand symdrome in reflex dystrophy of the upper extremity. Ann. Intern. Med. 1948; 29: $22-52$.

136. Sternberg A., Brickman S., Kott I., Reis R., Transaxillary thoracic sympathectomy for primary hyperhydrosis of the upper limbs. World. J. Surg. 1982;6:458-463

137. Stokes J.M., Butcher H.R., A comparison of thromboendarteriectomy and arter ial substitution as therapy for arterial occlusive disease using the life table method of reporting results. Surgery $1960 ; 48: 554-563$.

138. Stokes J.M., Sugg W.L., Butcher H.R., Standard method of assessing relatiwe effectiveness of therapies for arterial occlusive diseases. Ann Surg 1963; 1.57: 343-350.

139. Strandness D.E, Mc Cutcheon E.P., Rushmer R.F., Application of a transcutaneous Doppler flowmeter in evaluation of occlusive arterial disease. Surg. Gynecol. Obstet. 1966;122:1039-1045

140. Strandness D.E., Schultz R.D., Sumner D.S., Rusher R.F., Ultrasonic flow detection: a useful techmique in the evaluation of peripheral vascular disease. Am. J. Surg. 1967; 114:3111-320

141. Strandness D.E, Kennedy J.W., Judge T.P, Mc Leod F.D., Transcutaneous directional flow detection: a preliminary report. Am Heart J. 1969; 78: 65.74

142. Takats G. Miller D.S., Postraumatic dystrophy of the extremities. Arch. Surg. 1943;46:469-479

143. Takats, G., Analysis of results following sympathectomy for peripheral vascular diseasc. Am J Surg. $1940 ; 47 ; 78-86$.

144. Takats G., Fowler E.F., Raynaud's phenomenon. JAMA 1962; 179(1): 99.106

145. Telford E.D., The technique of sympathectomy. Br. J. Surg. 1935; 23:448-450

146. Telford E. D., Symparhetic denerwation of the upper extremity. Lancet 1938; 1: 70-72

147. Thompson J.E., The diagnosis and management of post-traumatic pain syndromes (causalgia). Aust. NZ. J. Surg. 1979; 49: 299-304

1.48. Touati Y., Matheu J.P., Houell F., Imbert P., Indications actuclles de tal sympathechomic dorsale supèrieur. J. Mal. Vasc. 1982; 7: 187-192

149. Vayssairat $M$., Et al. Résultats de sympathectomie thoracique dans le traitmeat de la phénomène de Raynaud. Coeur Med Int. 1979; 18: 401 1404.

150. v.d. Wal H.J.C.M., Skotnicki S.H., Wijn P.F.F., Lanquet L.K., Toracic sympathectony as a therapy for upper extremity ischemia. Tharac. Cardiovasc Surg. 1985; 33:181-187

151. v.d. Wal H.J.C.M., Quantitative diagnosis and treatment of vasospasm in upper extremities. Thesis University of Nijmegen 1986

152. Weale F.E., Upper thoracic sympathectomy by transthoracic electro-coagulation. Br. J. Surg. 1980;67: $71-72$

153. Welch E., Geary J., Current status of thoracic dorsal sympathectomy. I. Vasc. Surg. 1984; 1: 202-214

154. Welling R.E., Cranley J.J, Krause R.J, Hafner C.D., Obliterative arterial disease of the upper extremity. Arch Surg 1981; 116:1593-1596. 
155. Wellington J, L., Lyn R.B., Raynaud's Syndrome Angiology 1969; 20:129-135

156. White J.C., Smith wick R.H., Simeone F.A., The Autonomic Nerve System. 3rd. New York: Macmillan, 1952, P. 569.

157. Wiedkopf 0., Experimentelle Untersuchungen über die Wirkung der periarteriellen Sympathektomie und der Nerwenwereisung auf die Gefässe der Extremitäten. Berlin. Klin. Chir. 1923; 130:399 406

158. Winsor T. Bendezu J., Thermograplay and the peripheral circulation. Ann. Ny. Acad. Sci. 1964;135-157

159. Wrete M., Die Entwicklung der intermediaren Ganglien beim Menschen. Morphol. Jahrbuch 1935; Band $75: 229-268$ 


\section{Acknowledgements}

Many people have been involved in realising this thesis. I am greatfull for all their supports.

First of all I want to thank Patty and the children (Lars, Kai and David) for their tender support and patience. Patty, specially for the never lasting confidence you always had in me. The warm family tie gave me the strength to complete this thesis.

Dr. Paul Jörning I would like to express my deep appreciation for your encouragement and patience on discussing problems related to my work. Without your help I never had finished this manuscript.

In particular I wish to thank Professor Greep and Professor Lemmens for their critical contribution to this work.

For critical reading of the manuscript I specially like to thank the referees Professor Drukker, Professor Janevski and Professor Skotnicki.

I wish to thank Dr. Davies and Dr. Lawrence for correcting my English.

Dr. Cees van der Linden I thank you for your help often during hours at night in an 'air' of cigar-smook.

I feel much obliged to Iny, Mechteld, Carolien, Marcia, Marie-Jose and Lilian for their help in preparing the manuscript.

Chris Voskamp, I thank you for the high quality illustrations, the fine cover design and preparation of the lay-out.

Finally, I like to thank my parents for the confidence they always had in their son. 



\section{Curriculum Vitae}

Eric van Rhede van der Kloot was born on the 2nd of March 1955 in Leiden, The Netherlands. He attended high-school HBS-B in The Hague. From 1973-1981 he studied medicine at the Erasmus University of Rotterdam.

In 1982 he started his surgical residency training at the Department of Surgery of the Academic Hospital Maastricht (Chairman: Prof. Dr. J.M. Greep / February 1988 Prof. Dr. G. Koolstra).

Registration as a general surgeon is due in the course of 1988. 